UNIVERSIDADE DE SÃO PAULO

FACULDADE DE FILOSOFIA, LETRAS E CIÊNCIAS HUMANAS DEPARTAMENTO DE CIÊNCIA POLÍTICA

PROGRAMA DE PÓS-GRADUAÇÃO EM CIÊNCIA POLÍTICA

LEANDRO CONSENTINO

\title{
Ação coletiva na cadeia do etanol \\ O caso da certificação BSI-Bonsucro
}

VERSÃO CORRIGIDA

SÃO PAULO 


\section{Ação coletiva na cadeia do etanol \\ O caso da certificação BSI-Bonsucro}

Leandro Consentino

Tese apresentada ao Programa de

Pós-Graduação em Ciência Política

do Departamento de Ciência Política

da Faculdade de Filosofia, Letras e

Ciências Humanas da Universidade de

São Paulo para a obtenção do título

de Doutor em Ciências

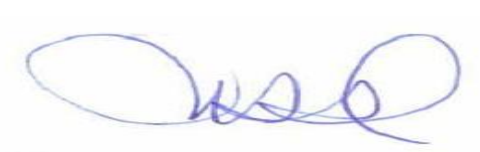

Orientadora: Professora Doutora Maria Hermínia Tavares de Almeida

VERSÃO CORRIGIDA

SÃO PAULO 
Autorizo a reprodução e divulgação total ou parcial deste trabalho, por qualquer meio convencional ou eletrônico, para fins de estudo e pesquisa, desde que citada a fonte.

Catalogação na Publicação

Serviço de Biblioteca e Documentação

Faculdade de Filosofia, Letras e Ciências Humanas da Universidade de São Paulo

C755a

Consentino, Leandro

Ação coletiva na cadeia do etanol - o caso da

certificação BSI-Bonsucro / Leandro Consentino ;

orientadora Maria Hermínia Tavares de Almeida. - São

Paulo, 2017.

$141 \mathrm{f}$.

Tese (Doutorado)- Faculdade de Filosofia, Letras

e Ciências Humanas da Universidade de São Paulo.

Departamento de Ciência Politica. Área de

concentração: Ciência Política.

1. Ação coletiva. 2. Certificações Internacionais. 3. Agroindústria Canavieira. 4. BSI-Bonsucro. I.

Tavares de Almeida, Maria Herminia, orient. II. Título. 
LEANDRO CONSENTINO

\title{
Ação coletiva na cadeia do etanol \\ O caso da certificação BSI-Bonsucro
}

\author{
Tese apresentada ao Programa de \\ Pós-Graduação em Ciência Política \\ do Departamento de Ciência Política \\ da Faculdade de Filosofia, Letras e \\ Ciências Humanas da Universidade de \\ São Paulo para a obtenção do título \\ de Doutor em Ciências
}

Local, de de

\section{BANCA EXAMINADORA}

Prof. a Dr. ${ }^{\text {a Maria Hermínia }}$

Parecer

Tavares de Almeida (Orientadora) 
Prof.() Dr.()ㅡㄹ

Parecer

Prof.(a) Dr.()

Parecer

Prof.(ํ) Dr.(a)

Parecer 
“A tarefa não é tanto ver aquilo que ninguém viu, mas pensar o que ninguém ainda pensou sobre aquilo que todo mundo vê."

Arthur Schopenhauer

"Para nós os grandes homens não são aqueles que resolveram os problemas, mas aqueles que os descobriram”.

Albert Schweitzer

"Tenho a impressão de ter sido uma criança brincando à beira-mar, divertindo-me em descobrir uma pedrinha mais lisa ou uma concha mais bonita que as outras, enquanto o imenso oceano da verdade continua misterioso diante de meus olhos".

Isaac Newton

"Respeitar as ideias alheias, deter-se diante do segredo de cada consciência, compreender antes de discutir, discutir antes de condenar. E rejeitar todo tipo de fanatismo".

Norberto Bobbio 


\section{AGRADECIMENTOS}

Este trabalho não seria realizado sem a ajuda fundamental de algumas pessoas e instituições, a quem dedico esta página de agradecimentos como símbolo de minha eterna e sincera gratidão.

Em primeiro lugar, a meu Pai Maior, a quem agradeço o dom da vida e do sucessivo recomeço, caminhando na senda evolutiva rumo à perfeição possível.

A meus pais Franscisco e Odete, que me guiaram os passos iniciais nesta vida e que ainda hoje estão presentes em todos os meus dias - o primeiro nos céus e a segunda na terra - vibrando a cada conquista e suportando cada dissabor, como se fossem deles.

A minha irmã Denise e meus sobrinhos Leonardo e Amanda por serem a mais bela ponte entre o meu passado e o meu futuro, na certeza de que ainda caminharemos bastante lado a lado.

A meus amigos - limeirenses, paulistanos e de outras paragens - que foram fundamentais tanto nas horas alegres como nas mais tristes, para que o ânimo da jornada não se esgotasse. Em especial aqui, menciono o Ivan Fernandes, cuja companhia começou na graduação e se estendeu até o Doutorado, na pessoa de quem homenageio todos os companheiros do POLMET, nosso grupo de estudos metodológicos.

Ao Departamento de Ciência Política da USP, com todos os seus funcionários e professores, fundamentais para que esse trabalho tivesse prosseguimento. Igualmente ao Instituto de Relações Internacionais, minha alma mater na Academia, e seus professores e funcionários, a quem tenho a honra de conhecer e admirar a mais de uma década.

Aos membros da Banca de Qualificação - Professor Doutor Wagner Pralon Mancuso e Professor Doutor João Paulo Candia Veiga - e de Defesa - Professora Doutora Janina Onuki, Professor Doutor Jacques Marcovitch, Professor Doutor João Paulo Candia Veiga e Professor Doutor Ricardo Sennes - que dedicaram parte de seu tempo para examinar este trabalho e me auxiliar a corrigir seus rumos, evidenciando os erros e qualificando os acertos.

Por último, e de forma alguma menos importante, à minha Professora Orientadora Professora Doutora Maria Hermínia Tavares de Almeida - cujo título de "orientadora" tão bem expressa o que ela se tornou ao longo desses mais de doze anos de convivência: 
uma fonte permanente de orientação no mundo acadêmico, mas também, para além dele, em minha vida pessoal e profissional.

Ressaltando que os eventuais acertos dessa tese possuem conexão direta com todos os citados, eximo-os de quaisquer erros que eu tenha cometido e cuja responsabilidade é estritamente minha, deixo meu sincero "Muito Obrigado". 


\section{RESUMO}

Esta tese de doutorado visa estudar e compreender os aspectos relativos às iniciativas de certificação socioambientais, buscando responder como elas se estruturam e como funcionam a partir de uma lógica de ação coletiva, tomando por base a cadeia de cana-de-açúcar em geral e o caso da BSI-Bonsucro em particular.

Para tanto, desenvolveremos uma revisão bibliográfica acerca do tema das certificações socioambientais, visando compreender o processo e as limitações acerca destes arranjos. Em seguida, procederemos a um estudo acerca do universo de análise em que nos debruçamos, qual seja, a cadeia de cana-de-açúcar, a qual esmiuçaremos em sua origem e características e nos indicadores dos principais mercados a ela associados: o de açúcar e o de etanol combustível.

A partir de então, iniciaremos o bloco analítico onde desenvolvemos um estudo de caso sobre a principal iniciativa de certificação socioambiental no âmbito do setor sucroalcooleiro: o BSI-Bonsucro. Nele, procuramos enunciar e analisar todos os critérios de sustentabilidade presentes na iniciativa e abrir caminho para a última seção, que consiste na análise propriamente dita do objeto à luz das teorias de ação coletiva, especialmente o Arcabouço de Análise e Desenvolvimento Institucional de Elinor Ostrom.

Palavras-chave: Ação coletiva; Agroindústria Canavieira; BSI-Bonsucro; Certificações Internacionais 


\section{ABSTRACT}

This doctoral thesis aims to study and understand the aspects related to socioenvironmental certification initiatives, seeking to answer how they are structured and how they work based on a logic of collective action, based on the sugarcane chain in general and the Case of BSI-Bonsucro in particular.

To do so, we will develop a bibliographical review about the subject of socioenvironmental certifications, in order to understand the process and the limitations on these arrangements. Next, we will study the universe of analysis in which we are concerned, that is, the sugarcane chain, which we will analyze in its origin and characteristics and in the indicators of the main markets associated with it: sugar And that of fuel ethanol.

From then on, we will start the analytical block where we developed a case study about the main socio-environmental certification initiative in the scope of the sugar and alcohol industry: BSI-Bonsucro. In it, we seek to enunciate and analyze all the sustainability criteria present in the initiative and make way for the last section, which consists in the analysis of the object itself in the light of collective action theories, especially the Elinor Ostrom's Institutional Analysis and Development Framework.

Key Words: Collective action; Sugarcane agro-industry; BSI-Bonsucro; International Certifications 


\section{SUMÁRIO}

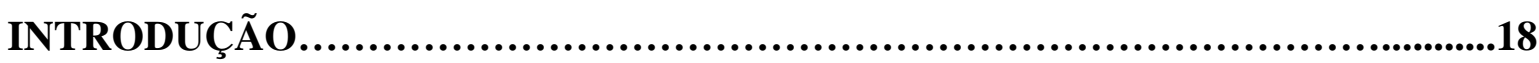

Capítulo 1. Aspectos conceituais sobre a certificação socioambiental.....................24

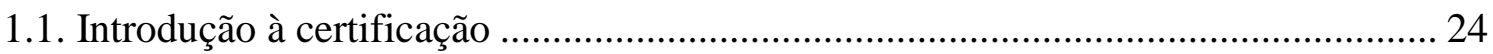

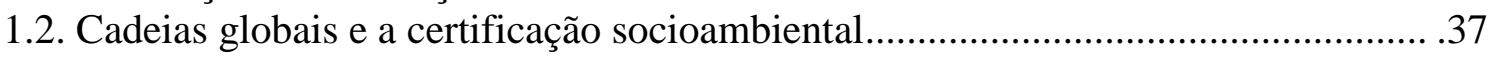

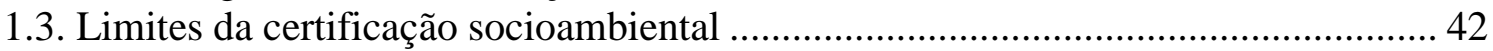

Capítulo 2. A cadeia internacional de açúcar e etanol de cana.........................46

2.1. O setor sucroalcooleiro: histórico e características ................................................. 46

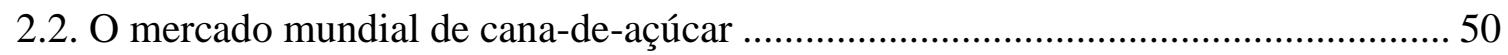

2.3. Certificações socioambientais na cadeia da cana-de-açúcar...................................62

Capítulo 3. Estudo de caso: BSI-Bonsucro.......................................66

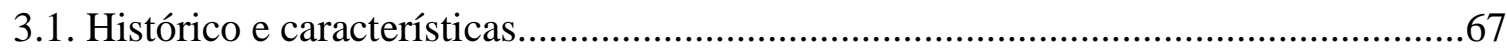

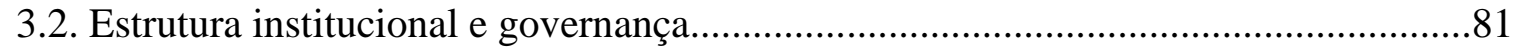

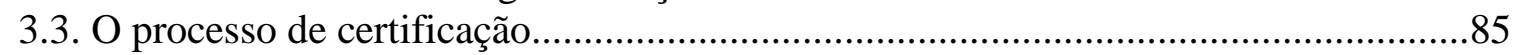

Capítulo 4. Ação coletiva no modelo de certificação da cana..........................89

4.1. A ação coletiva como problema na Ciência Política................................................89

4.2. As iniciativas de certificação como problema de ação coletiva: o BSI-Bonsucro sob

a ótica de Mancur Olson e Elinor Ostrom......................................................................99

4.3. Considerações finais e agenda de pesquisa...........................................................106

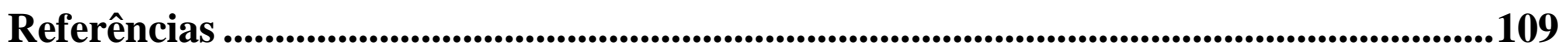

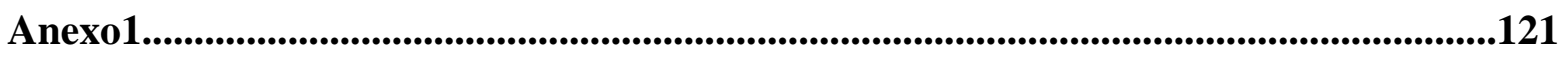

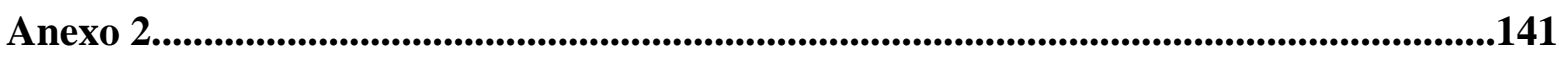




\section{ÍNDICE DE FIGURAS, GRÁFICOS, QUADROS E TABELAS}

\section{FIGURAS}

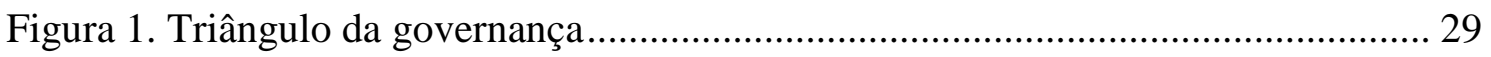

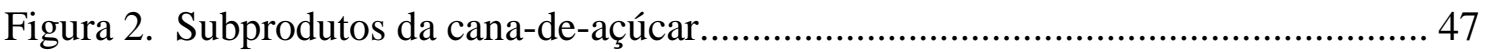

Figura 3. Processo de produção em uma usina de cana-de-açúcar............................... 48

Figura 4. Cadeia produtiva da cana-de-açúcar ............................................................ 49

Figura 5. Mandatos de mistura e políticas públicas para o uso de etanol ......................58

Figura 6. Mecanismos propostos para governança da bioenergia..................................65

Figura 7 . Fluxograma de Critérios do BSI-Bonsucro para o Princípio I - Observação estrita da legalidade

Figura 8. Fluxograma de Critérios do BSI-Bonsucro para o Princípio II - Respeito aos

Direitos Humanos e aos padrões trabalhistas .............................................................. 70

Figura 9. Fluxograma de Critérios do BSI-Bonsucro para o Princípio III - Administrar os insumos, a produção e a eficiência em prol da sustentabilidade.

Figura 10. Fluxograma de Critérios do BSI-Bonsucro para o Princípio IV -

Administração da Biodiversidade.

Figura 11. Fluxograma de Critérios do BSI-Bonsucro para o Princípio V - Melhora constante das áreas-chave

Figura 12. Fluxograma de Critérios do BSI-Bonsucro para o Princípio VI - Adequação à Diretiva de Renováveis promulgada pela União Europeia............................................75

Figura 13. Esquema para filiação das organizações no BSI-Bonsucro............................83

Figura 14. Rivalidade e exclusividade em Samuelson (1954).....................................90

Figura 15. Comunicação e informações no trabalho de Elinor Ostrom............................95

Figura 16. Reputação, Reciprocidade e Confiança para aumentar os níveis de cooperação

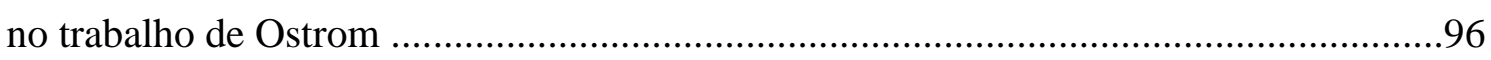

Figura 17. Arcabouço de Análise e Desenvolvimento Institucional ou IAD Framework 


\section{GRÁFICOS}

Gráfico 1. Produção Internacional de açúcar por país - Safra 2015/2016. .51

Gráfico 2. Consumo Internacional de açúcar por país - Safra 2015/2016. .53

Gráfico 3. Exportação de açúcar por país - Safra 2015/2016 54

Gráfico 4. Produção Global de Biocombustíveis (2000-2020) 55

Gráfico 5. Consumo Mundial de Energia por tipo de combustível (1990-2030) .56

Gráfico 6. Produção Internacional de etanol por país - Safra 2015/2016

Gráfico 7. Volume e área de cana-de-açúcar certificada no BSI-Bonsucro (2011-2015)

Gráfico 8. Volume de açúcar e etanol de cana-de-açúcar certificados no BSI-Bonsucro (2011-2013) - em megatoneladas. 80

\section{QUADROS}

Quadro 1. Stakeholders e seus interesses no processo de certificação

Quadro 2. Variedades de regulação..

Quadro 3. Tipologia para padrões de certificação. 33

Quadro 4. Evolução dos padrões socioambientais de certificação. .34

Quadro 5. Tipos de governança e suas características 39

Quadro 6. Ganhos obtidos no processo de regulação....

Quadro 7. Impactos ambientais e sócio-econômicos causados pela cadeia de cana-deaçúcar.

Quadro 8. Datas das revisões dos critérios da certificação BSI-Bonsucro 86

Quadro 9. Dois tipos de certificação expedidos pelo BSI-Bonsucro 87

Quadro 10. Taxonomia dos grupos em Olson (1999) 92 
Quadro 11. Princípios de governança de Ostrom no BSI-Bonsucro.....

100

Quadro 12. Variáveis Exógenas ao caso BSI-Bonsucro no Modelo IAD de Ostrom....103

Quadro 13. Regras operacionais e seus efeitos no BSI-Bonsucro. 104

\section{TABELAS}

Tabela 1. Produção Mundial de cana-de-açúcar por país (2015)

Tabela 2. Principais iniciativas de certificação para biocombustíveis, sua natureza e os responsáveis

Tabela 3. Número de membros por país de origem no BSI-Bonsucro............................76

Tabela 4. Número de membros por setor no BSI-Bonsucro.........................................78

Tabela 5. Número de usinas certificadas por país no BSI-Bonsucro...............................80

Tabela 6. Número de usinas certificadas por grupo empresarial no BSI-Bonsucro........81 


\section{ÍNDICE DE SIGLAS}

ABFA - Advanced Biofuels Association

ABNT - Associação Brasileira de Normas Técnicas

AIE - Agência Internacional de Energia

BEFSCI - Bioenergy and Food Security Criteria and Indicators

BID - Banco Interamericano de Desenvolvimento

BNS - Biomass Nippon Strategy

BP-Tropical - British Petroleum Tropical

BSI - Better Sugar Initiative

CBD - Convention on Biological Diversity

CMAA - Companhia Mineira de Açúcar e Álcool

CPR - Common Pool Resource

CSBP - Council on Sustainable Biomass Production

DEPEC - Departamento de Pesquisa Econômica

ETI - Ethical Trading Initiative

EUA - Estados Unidos da América

FAO - Food and Agriculture Organization

FLA - Fair Labor Association

FMI- Fundo Monetário Internacional

FSC - Forest Stewardship Council

GBEP - Global Bioenergy Partnership

GEE- Gases de Efeito Estufa

IAD Framework - Institutional Analysis and Development Framework

IASB - International Accounting Standards Boards 
ICC - International Chamber of Comerce

IDB - Inter-American Development Bank

IEC - International Eletrotechnical Comission

IFC - International Finance Corporation

ILUC - Indirect Land Use Change

ISCC - International Sustainability \& Carbon Certification

ISO - International Organization for Standardization

LDC - Louis Dreyfus Company

LCFS - Low Carbon Fuel Standard

MSC - Marine Stewardship Council

MSI - Multi Stakeholder Initiatives

NEN - Netherlands Standardization Institute

NSDM - Non-State Market Driven

NTA 8080 - Netherlands Technical Agreement 8080

OCDE - Organização para a Cooperação e o Desenvolvimento Econômico

OI - Organização Internacional

OIT - Organização Internacional do Trabalho

OMC - Organização Mundial do Comércio

ONG - Organização Não-Governamental

ONU - Organização das Nações Unidas

RED EU - Diretiva Europeia para Energia Renovável

RBSA - RED Bioenergy Sustainability Assurance

RFS - Renewable Fuel Standard

RFTO - Renewable Transport Fuel Obligation

RSE - Padrões de Responsabilidade Social Empresarial

RSPO - Roundtable on Sustainable Palm

RTRS - Roundtable on Sustainable Soy(RSB - Soja) 
SEKAB - Svensk Etanolkemi AB

UE - União Europeia

UNICA - União da Indústria da Cana-de-Açúcar

USDA - United States Department of Agriculture

VSE - Verified Sustainable Ethanol

WWF - World Wide Fund for Nature 


\section{INTRODUÇÃO}

\section{Apresentação}

As modernas cadeias globais do agronegócio têm se estruturado por meio de uma preocupação que diz respeito tanto aos aspectos produtivos e logísticos como a certos padrões de sustentabilidade ambiental e social, bastante difundidos nestes últimos anos ao redor do globo. Nesse sentido, alguns arranjos de múltiplos atores - no original multistakeholder initiaves ou, na sigla em inglês, MSIs - emergiram em diversos setores para buscar a coordenação e a representação dos interesses associados a tais cadeias, configurando uma questão candente nas relações comerciais em escala mundial.

O presente trabalho tem como objetivo compreender a ação coletiva em torno da constituição e da governança destes esquemas de certificação, articulando a literatura que trata da chamada governança privada internacional com os conceitos de autores como Garret Hardin (1968), Mancur Olson (1971), e Elinor Ostrom (1990), tomando como base o setor sucroalcooleiro e o caso do BSI-Bonsucro, sua mais abrangente iniciativa de certificação.

É possível compreender a ação coletiva em torno da iniciativa BSI-Bonsucro como provedora tanto de bens públicos como de bens de clube (Chaddad e Moura, 2012), nos moldes enunciados por Olson. Por um lado, trata-se de um bem público na medida em que provê, como externalidade positiva a toda sociedade, práticas mais sustentáveis na produção e no manejo que visam reduzir o impacto socioambiental na cadeia de cana-de-açúcar, sem qualquer rivalidade ou exclusividade nestes benefícios para a sociedade como um todo.

De outro lado, a participação no processo decisório seria um bem de clube ao passo que constitui uma característica exclusiva daqueles que compõem a iniciativa, previamente aprovados pelo conselho de diretores que a comanda pautando-se pelos próprios interesses, gerando potenciais conflitos entre os estabelecidos e os candidatos.

Diante disso, fica patente que um resultado melhor - tanto para a sociedade como um todo no primeiro caso quanto para os membros da iniciativa no segundo caso 
- poderia ser alcançado, caso a cooperação estivesse garantida neste arranjo. No entanto, a teoria clássica de ação coletiva, notabilizada por Olson, afirma que a cooperação acabaria não ocorrendo, dado que, devido às características do grupo, os atores não veriam razões para fazê-lo ante a probabilidade de que os demais não os seguissem, gerando um resultado necessariamente pior para todos.

Ante a esse diagnóstico, recorremos aos trabalhos de Ostrom para compreender as razões pelas quais, contraintuitivamente, os atores do BSI-Bonsucro buscaram - entre a completa desregulamentação e a mera adesão aos mecanismos estatais - o caminho da auto-regulação, criando um arranjo dotado de uma série de critérios e indicadores com os quais se comprometeram.

Tais características precisam ser compreendidas à luz do que ocorreu em cada momento na iniciativa BSI-Bonsucro, alinhavando cada uma das arenas e a relação entre os membros, como faremos neste trabalho mais adiante. Diante disso, precisamos começar retomando o processo de regulação do comércio internacional desde seus primórdios, notadamente no que concerne aos mecanismos de coordenação entre os atores envolvidos.

Este processo remonta aos primórdios do capitalismo, com raízes em instituições como as guildas e as corporações medievais, as quais possuíam o mandado de regulação nos mercados em formação. A partir da emergência dos estados nacionais como centro da vida política e social no Ocidente - notadamente a partir da Paz de Westfália, em 1648 - estes se tornaram os principais centros de produção e execução de normas, inclusive no que diz respeito às leis de mercado. Com o passar dos anos, os processos políticos cristalizaram-se no âmbito intra e intergovernamental, seja no âmbito dos Estados, seja no das Organizações Intergovernamentais (Avant, Finnemore e Sell, 2010).

De acordo com King \& Terlaak (2006), esta estrutura centrada nos estados começou a sofrer alterações quando, já no século $\mathrm{XX}$, as cadeias internacionais de oferta de produtos, essencialmente insumos agrícolas, começaram a se tornar cada vez mais complexas, contemplando novos atores como empresas multinacionais e organizações de terceiro setor, impossibilitando aos consumidores o pleno discernimento com relação a seus padrões de qualidade na produção e manejo.

Nesse sentido, criou-se um problema de assimetria de informação entre os vendedores e os demandantes dessas cadeias, cujo enfrentamento levou à construção dos processos de certificação por meio de standards ou padrões de produção ligados à 
esfera social e, sobretudo, ambiental, ancorados numa governança de caráter transnacional, inaugurando uma fase de importante inovação institucional ao redor do globo. (Hale e Held, 2011).

Dessa forma, segundo Keohane \& Nye (1989), a perspectiva institucionalista auxilia a compreensão sobre a dinâmica da cooperação internacional e da construção de instituições na ausência de uma autoridade central, ou seja, a forma como agem coletivamente os atores para a resolução de problemas comuns.

\section{Definição do Objeto, Objetivos e Questão de Pesquisa}

De acordo com Short \& Toffel (2010), está cada vez mais clara a adesão das corporações a estes arranjos de certificação privada, mas é necessário verificar se tais esquemas têm produzidos mudanças capazes de produzir algum tipo de bem público ou, antes, compreender suas implicações em termos de ação coletiva.

Ao lançarmos luz sobre esta questão, precisamos entender antes a natureza de nosso objeto de análise da maneira mais simples possível. Para tanto, é valiosa a definição de Chaddad \& Moura (2012), em que os autores afirmam que:

"estes arranjos consistem em sistemas de governança cujo objetivo é regular as negociações e promover práticas de sustentabilidade, por meio da coordenação de um grande número de atores orientados em direção à construção de consensos, representação de interesses, compartilhamento de conhecimento e construção $e$ monitoramento de práticas sustentáveis."

De posse deste conceito, o presente trabalho buscará conhecer, como questão de pesquisa fundamental, a formação dessas iniciativas de certificação e como se dá a coordenação dos atores envolvidos para alcançar suas metas, por meio da análise de estudo de caso do arranjo BSI-Bonsucro, delimitando assim, os seguintes objetivos:

- Compreender a questão da certificação e seus desdobramentos para as relações comerciais internacionais

- Estabelecer uma análise da literatura sobre o setor de açúcar e etanol para compreender o lugar das certificações na referida cadeia. 
- Proceder a um estudo pormenorizado do BSI-Bonsucro, identificando as etapas de constituição e os atores envolvidos bem como sua dinâmica interna

- Identificar a ação coletiva concernente à governança privada internacional, especialmente aquela estabelecida em iniciativas de certificação.

Para desenvolver esta pesquisa, seguiremos o roteiro traçado no início deste trabalho, delimitando cada capítulo para uma determinada função específica. Assim, após a presente introdução, o capítulo 1 buscará realizar uma ampla revisão bibliográfica acerca dos aspectos conceituais da regulação transnacional, analisando a contribuição das diversas literaturas neste campo e situando este trabalho em meio a seus pares.

No capítulo 2, o objetivo será compreender o funcionamento da cadeia de açúcar e etanol biocombustível de cana da maneira mais completa possível, estudando os atores que a compõe, os processos de barganha em seu interior e algumas tecnicalidades relevantes ao presente trabalho. A compreensão do mercado internacional de etanol e das ações de seus principais players será de especial importância para este estudo, principalmente face aos novos desdobramentos acerca do setor.

Para o capítulo 3, reservaremos o estudo de caso a que nos referimos acima. $\mathrm{O}$ caso do principal arranjo de certificação multistakeholder para o etanol combustível BSI-Bonsucro - será utilizado para compreender a certificação em um setor específico, reconstituindo a dinâmica de formação e operação de tal iniciativa bem como sua implementação.

Por fim, o capítulo 4 será de suma importância ao mobilizar a literatura de ação coletiva e realizar a análise do modelo de governança dos arranjos de certificação de tipo multistakeholder e buscar explicar como se dá o processo de negociação e de acesso aos selos/certificados por meio do modelo de Ostrom, denominado IAD Framework ou Modelo Institucional de Desenvolvimento.

Nesse sentido, nossa opção metodológica pelo estudo de caso, lastrado naquilo que George \& Benett (2005) chamaram de process tracing - ou delineamento do processo - buscou justamente embasar as informações para que pudéssemos aplicar, com mais propriedade, o modelo citado.

De acordo com King, Keohane \& Verba (1994), uma das formas de produzir uma boa pesquisa em ciências sociais seria aplicar um modelo teórico já existente para elucidar questões aparentemente não relacionadas com ele. Dessa forma, as teorias da 
ação coletiva podem, ainda que em casos distintos daqueles em que se debruçam usualmente, iluminar tópicos acerca da cooperação nestes arranjos. Com base nisso, trataremos de reafirmar, no campo das conclusões, da delimitação da área em que se insere tal estudo, situando a contribuição deste trabalho com vistas a compor uma agenda de pesquisa cada vez mais desenvolvida na Ciência Política e nas Relações Internacionais.

\section{Metodologia}

Este trabalho foi elaborado com base na metodologia de estudo de caso consiste em uma análise intensiva de um fenômeno espacialmente delimitado, observado em um determinado período. De acordo com Gerring (2004), tal metodologia guarda um importante poder explicativo, que aumenta de acordo com o número de observações no espaço e no tempo - levadas a cabo pelo pesquisador. Além disso, o autor em tela neste trabalho e em outros - sugere que o caso de melhor poder explicativo seja, frequentemente, o que chama de "caso típico", o qual sintetizaria o paradigma principal a ser estudado.

Nesse sentido, Brady, Collier \& Searight (2006) enfatizam a importância de resgatar a trajetória do processo causal, inscrito naquilo que George \& Bennet (2005) chamaram de delineamento do processo, ou no original, process tracing. Diante da dificuldade de validação das entrevistas no caso do envolvimento de uma ampla gama de atores, optamos por recorrer à literatura já consolidada neste campo para descrever os processos e características do setor sucroalcooleiro.

Dessa forma, nosso trabalho buscou reconstituir o processo de certificação da cadeia de cana de açúcar com base em dados secundários oriundos de estudos como o de Neves e Zylberstajn (2000), Marcovitch (2012), Liboni (2009) e Santos (2014), destacando as seguintes etapas:

(I) A coleta e a sistematização de dados do setor sucroalcooleiro com base em (i) anuários estatísticos, marcos regulatórios e dispositivos legais do setor sucroalcooleiro no Brasil e dos mercados-chave a ele associados; (ii) documentos e relatórios internos de associações ligadas ao setor em nível nacional e internacional; v) artigos acadêmicos e não-acadêmicos 
sobre o processo de certificação socioambiental e do setor sucroalcooleiro; vi) sítios oficiais, setoriais e da imprensa que tratem sobre a evolução do setor e variáveis quantitativas e qualitativas e vii) anuários estatísticos sobre $\mathrm{o}$ setor e setores correlatos (como o automotivo), entre outras fontes.

(II) A formulação de um road map acerca dos processos de certificação socioambiental, dos aspectos mais gerais aos mais específicos relacionados ao setor sucroalcooleiro, buscando situar o arranjo do BSIBonsucro em uma tipologia específica, a fim de proceder a uma análise mais acurada de sua estrutura e de seus processos internos.

(III) A utilização destes dados para subsidiar a análise das iniciativas de certificação à luz de uma lógica de ação coletiva explicitada no último capítulo deste trabalho, enfatizando o nível de coordenação dos atores sob o ponto de vista dos trabalhos clássicos de Mancur Olson e Elinor Ostrom. 


\section{CAPÍTULO 1: ASPECTOS CONCEITUAIS DA CERTIFICAÇÃO}

\subsection{Introdução ao conceito de certificação}

Com o fim da Guerra Fria e o advento daquilo que se convencionou chamar de globalização, os Estados vêm paulatinamente deixando de ocupar o papel de únicos atores relevantes no cenário internacional. Nesse sentido, alguns autores apontam para a emergência de uma maior pluralidade de fontes de autoridade nas relações internacionais neste cenário. Para Avant, Finnemore \& Sell (2010), aos fatos políticos do fim da bipolaridade e aos desdobramentos econômicos como a integração e a desregulamentação de mercados, unem-se o avanço tecnológico e a redefinição do papel de alguns atores ou stakeholders no cenário internacional.

Esta redefinição da governança global se daria de diversas formas, apontando para a erosão do papel preponderante dos estados e a constituição de novas formas de integração entre os atores, conforme aponta a tipologia construída por Hale \& Held (2011): i) redes transgovernamentais tais como o G-20; ii) órgãos de arbitragem como o Painel de Inspeção do Banco Mundial ${ }^{1}$; iii) iniciativas multistakeholder como o BSIBonsucro; iv) regulação voluntária como os Princípios do Equador $^{2}$ e v) mecanismos financeiros como o mercado de compensações de crédito de carbono implementado no Protocolo de Kyoto.

Em comum, é possível afirmar que todos esses mecanismos de governança produzem um determinado conjunto de regras e instituições, pulverizando o monopólio de criação e aplicação de normas, outrora privativa dos estados nacionais e das organizações intergovernamentais compostas exclusivamente por eles. Seu papel, dessa forma, tem sido cada vez mais preponderante no cenário internacional e sua compreensão torna-se cada vez mais fundamental.

\footnotetext{
${ }^{1}$ Originalmente World Bank Inspection Panel, constitui uma espécie de instância de apelação para aqueles que se sentem afetados por consequiências causadas por projetos do Banco Mundial.

${ }^{2}$ Os Princípios do Equador são critérios socioambientais estabelecidos pelo Banco Mundial para a concessão de crédito, estabelecidos em 2002 e adotados por grandes conglomerados bancários de atuação global.
} 
Assim, o primeiro passo para compreender a questão da certificação é a conceituação do tema e a realização de uma revisão bibliográfica ligada a ele, inscrita no marco teórico da chamada governança privada transnacional. Para tanto, começamos com a definição mínima do conceito, enunciada por Conceição e Barros (2005) para quem:

" a certificação consistiria na definição de atributos de um produto, processo ou serviço e a garantia de que eles se enquadrem em normas pré-definidas, envolvendo normas - seja na esfera pública, privada ou internacional - e um ou mais órgãos certificadores com poder de monitoramento e exclusão."

(CONCEIÇÃO, J. C. P. R. da; BARROS, A. L. M., 2005)

Nesse sentido, é digno de nota que tal definição guarda uma profunda relação com a iniciativa e as motivações dos atores envolvidos no processo, os quais guardam interesses específicos determinantes para a construção do arcabouço normativo presente nestas iniciativas, conforme exposto por Levandowski \& Faaji (2006), no Quadro 1:

Quadro 1 - Stakeholders e seus interesses no processo de certificação

\begin{tabular}{|c|c|}
\hline STAKEHOLDERS & INTERESSES NO PROCESSO DE CERTIFICAÇÃO \\
\hline Indústria e Comércio & 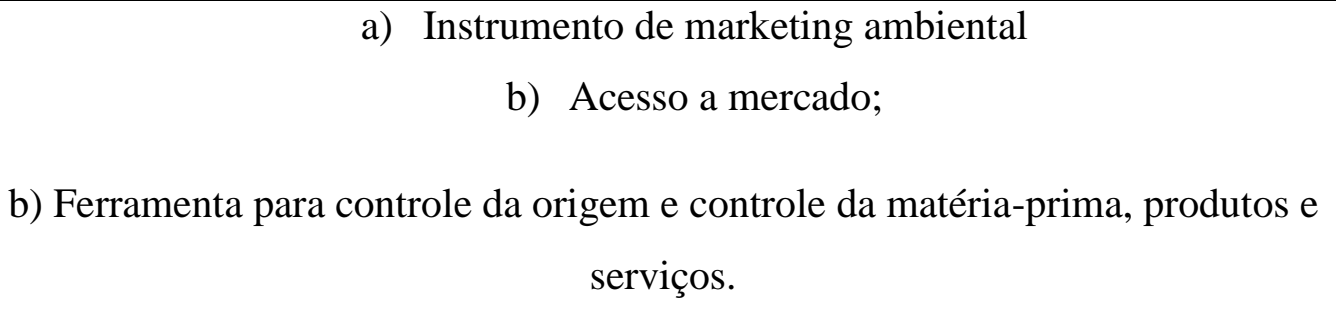 \\
\hline $\begin{array}{c}\text { Consumidores e } \\
\text { Compradores }\end{array}$ & $\begin{array}{l}\text { a) Fornecimento de informação a respeito dos produtos consumidos; } \\
\text { b) Melhorar a confiança nos produtos; } \\
\text { c) Fornecimento de informação acerca da qualidade ou dos padrões } \\
\text { técnicos do produto }\end{array}$ \\
\hline
\end{tabular}




\begin{tabular}{|c|c|}
\hline $\begin{array}{c}\text { Produtores e } \\
\text { administradores }\end{array}$ & $\begin{array}{l}\text { a) Ferramenta para acesso a mercado e/ou vantagens no interior do } \\
\text { mercado; } \\
\text { b) Fornecimento de informação para otimização do processo produtivo; } \\
\text { c) Permite a diferenciação dos produtos }\end{array}$ \\
\hline Governos & $\begin{array}{l}\text { a) Instrumento de políticas para promover o gerenciamento da } \\
\text { sustentabilidade e um padrão de consumo sustentável; } \\
\text { b) Fornecimento de informação para otimização do processo produtivo; }\end{array}$ \\
\hline
\end{tabular}

Fonte: Levandowski \& Faaji (2006) baseado em Ramesteiner \& Simula (2003), adaptada e traduzida pelo autor.

Como podemos observar, os interesses de cada stakeholder envolvido no processo são diversos e multifacetados. O primeiro grupo, onde estão agregados os setores industrial e comercial, utilizam a certificação como instrumento de marketing visando ganhos reputacionais, formas de acesso a mercados regulamentados e ferramentas informacionais para controle de origem das matérias-primas, produtos e serviços.

O segundo grupo, dos consumidores, busca essencialmente ganhos informacionais (tanto em aspectos de consumo como em critérios técnicos) com fins de ampliar a confiança naquilo que estão adquirindo. Já o terceiro grupo - de produtores e administradores - visa essencialmente o acesso ou vantagens no interior do mercado em que atuam, informações acerca de otimização de processos e técnicas e a diferenciação de produtos via construção de marcas.

Por fim, para o quarto e último grupo - os governos nacionais e subnacionais - a certificação se destina ao fornecimento de informações e a constituir um importante instrumento para a criação e gerenciamento de políticas públicas no âmbito em que ela se debruça.

$\mathrm{Na}$ esteira da busca destes interesses, os processos de certificação têm ultrapassado as fronteiras nacionais e a organização e o controle de atividades políticas, econômicas e sociais por meio de criação, implementação, monitoramento e enforcement de regras têm se estabelecido entre estados e organizações 
intergovernamentais, entre estas e suas agências subsidiárias ou com organizações nãogovernamentais e, pioneiramente prescindindo de um ente estatal, entre o setor privado e o terceiro setor ${ }^{3}$.

Diante desta multiplicidade de regulações, Lodge e Wegrich (2009) formularam um quadro-resumo que associa, de maneira bastante simples, os atores responsáveis pela regulação (quem regula?) com as diferentes formas do exercício dessa regulação (como regular?), conforme podemos observar no quadro 2.

\section{Quadro 2 - Variedades de Regulação}

\begin{tabular}{|c|c|c|c|}
\hline & \multicolumn{2}{|c|}{ Quem regula? } \\
\hline & & Governo & Setor Privado \\
\hline \multirow[b]{2}{*}{$\begin{array}{l}\text { Como } \\
\text { regular? }\end{array}$} & Comando e Controle & I- Regulação estatal & II- (Auto) regulação \\
\hline & Alternativas & $\begin{array}{l}\text { III- Uso de incentivos } \\
\text { de } \\
\text { autocontrole e outras } \\
\text { abordagens baseadas } \\
\text { em auditoria e gestão }\end{array}$ & IV-Mercados e normas \\
\hline
\end{tabular}

Fonte: Lodge e Wegrich (2009) traduzido por Lima (2010)

A partir do quadro acima, é possível perceber que a maneira de exercer a regulação se desdobra em duas formas distintas, chamada pelos autores de "comando e controle" de "alternativas".

As formas de regulação inscritas na categoria "comando e controle" dizem respeito àquelas em que o agente regulador dispõe de instrumentos para impor sanções ao ente regulado, caso ele descumpra o rol de requisitos presentes neste regulamento. No caso desse tipo de regulação, há duas possibilidades de classificação: quando o governo é o agente regulador, os autores denominam de (I) regulação estatal; já no caso do setor privado ser o agente regulador o conceito é o da (II) auto-regulação.

No caso das formas "alternativas" de regulação, onde os atores não utilizam ou não dispõem de sanções, as variedades de regulação se dividem entre o (III) uso de

\footnotetext{
${ }^{3}$ Mattli \& Woods, 2009
} 
incentivos de mercado e de controle baseados em mecanismos de auditoria e gestão, quando o agente regulador é o governo, e (IV) a regulação apenas pelo mercado e suas normas, quando quem regula é o setor privado.

Tal concepção, a despeito de didática, ignora o fato de que a linha que distingue, atualmente, as prerrogativas dos governos, das corporações e do terceiro setor é cada vez mais tênue e a emergência de novos atores e de novas fontes de autoridade legítima no que diz respeito à criação de regras tem realocado ou redefinido a governança global para novos arranjos em níveis transnacionais.

Este movimento tem sido de tal monta que levou Lipschutz \& Fogel (2002) a classificarem-no como a "nova divisão global da atividade regulatória" e Abott \& Snidal (2009) a definirem sua natureza como a de estruturas capazes de superar as falhas estatais no que diz respeito à assimetria de informação e expertise técnica em determinadas áreas.

A diversidade destes arranjos é bastante ampla e compõe um amplo mosaico de relações entre diversos atores. Para Abott \& Snidal (idem), a articulação entre três tipos principais de atores - estados nacionais, corporações e organizações nãogovernamentais - compõem aquilo que os autores denominaram como o Triângulo da Governança (Figura 1), exposto abaixo: 


\section{Figura 1 - Triângulo da governança}

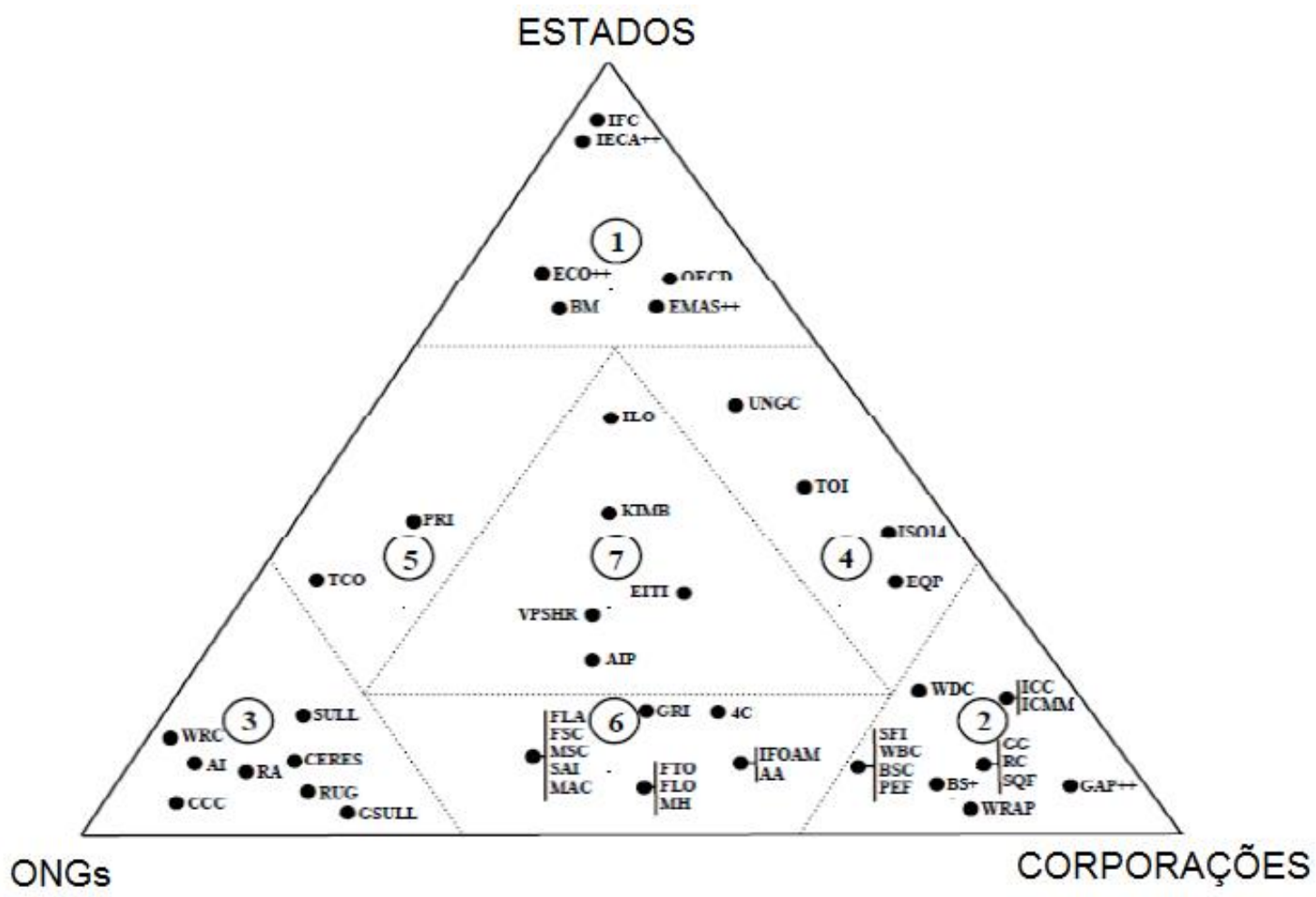

Fonte: Abott \& Snidal (2009) adaptado pelo autor

Neste triângulo, os autores mapeiam alguns arranjos de certificação denominados por eles como Sistemas de Estabelecimento de Padrões Regulatórios ${ }^{4}$ - em uma tipologia de sete formas, de acordo com a natureza dos atores que as compõem: (1) iniciativas compostas somente por estados nacionais; (2) iniciativas compostas somente por corporações; (3) iniciativas compostas somente por organizações nãogovernamentais; (4) iniciativas onde se articulam estados e corporações; (5) iniciativas onde se articulam estados e organizações não-governamentais; (6) iniciativas onde se articulam organizações não-governamentais e corporações e finalmente (7) iniciativas caracterizadas pela coordenação dos três atores.

Com tal mapeamento, fica patente que a interação entre os vértices é bastante profícua no campo das regulações, demonstrando que não é mais possível situar os arranjos de certificação como unicamente provenientes de um só ator, a despeito de

\footnotetext{
${ }^{4}$ No original, Regulatory Standard Setting Systems.
} 
alguns ainda se constituírem desta forma. Além disso, é possível perceber que os estados nacionais tornaram-se atores periféricos no processo, liderado essencialmente pelas corporações e pelas ONGs, como será o caso que analisaremos mais adiante.

É importante frisar, contudo, que ainda que o triângulo de Abott \& Snidal tenha a virtude de trazer à luz tais questões, este referencial teórico não traz explicações mais detalhadas sobre os mecanismos de constituição e cooperação que levam os atores a constituírem tais iniciativas. Desta forma, para compreender melhor como os atores engendraram mecanismos de governança em torno de seus respectivos setores, recorreremos à literatura de governança transnacional - por meio dos trabalhos de Pattberg (2004, 2006), Cashore (2002), Gereffi \& Meyer (2010) e Büthe e Mattli (2011) - abordando alguns temas candentes.

Os dois trabalhos de Pattberg - ambos estudos de caso sobre o FSC F $^{5}$ abordam a problemática da legitimidade do sistema decisório por meio dos atores privados envolvidos nas iniciativas, denominadas "redes auto-coordenadas", que se valem dos "espaços vazios" deixados pelos estados nacionais. Nesta abordagem, é fundamental compreender as regras pelas quais os atores se coordenam, uma vez que serão elas a maior fonte de autoridade perante uma pretensa horizontalidade.

Apesar de suscitar a questão da legitimidade, a análise pormenorizada deixa de lado, contudo, a lógica que orienta os atores a realizarem o compliance com as regras estabelecidas, ou seja, o que os levaria a se comprometer com as regras, na ausência de uma autoridade centralizada.

Para dar conta desta questão, o trabalho de Cashore (2002) demonstra a necessidade de um processo de adaptação dos atores de determinadas cadeias produtivas a uma lógica de incentivos determinados para que estes se comprometam com as regras do que o autor chama de Sistemas Regulatórios Não-Estatais Dirigidos pelo Mercado ${ }^{6}$. Cabe pontuar que esta adaptação não ocorre livre de pressões sociais, políticas e econômicas, como atestam Gereffi \& Meyer (2010), evidenciando a necessidade de buscarmos modelos explicativos para o surgimento de tais iniciativas com base em tais interações.

\footnotetext{
${ }^{5}$ FSC é a sigla, em inglês para Forest Stewardship Council, uma iniciativa pioneira de regulação no âmbito florestal.

${ }^{6}$ Em inglês, o termo original é Non-State Market Driven (NSMDs) Regulatory Systems
} 
Um modelo bastante elucidativo acerca do surgimento de tais arranjos é aquele formulado por Büthe e Mattli (2011) e adaptado por Donadelli (2012), apresentado no quadro 3 abaixo. Neste referencial, os autores correlacionam o contexto institucional em que se estabelecem as regras das iniciativas - se público ou privado - com os mecanismos de seleção destes regulamentos - baseados ou não no mercado - para determinar a criação desses arranjos.

No caso de o contexto institucional em que a criação das regras se der for público, existem duas possibilidades. Uma primeira hipótese é aquela que correlaciona essa natureza pública com mecanismos de seleção não baseados no mercado, produzindo (i) marcos regulatórios a partir de tratados internacionais ou constituição de organizações internacionais. Nesse sentido, estamos verificando iniciativas ainda atreladas ao âmbito inter-estatal, onde a soberania e o poder de sanção deste ente condicionam as regulações, podendo citar como exemplos tratados multilaterais como o Protocolo de Quioto ou a criação de organizações intergovernamentais como a Organização Internacional do Trabalho (OIT) ou o Fundo Monetário Internacional (FMI).

Já no caso de persistir o contexto público, mas correlacionado com mecanismos de seleção lastreados no mercado, verificar-se-ão (ii) padrões de alcance regional, nacional ou bilateral, promovidos por órgãos públicos e/ou agências reguladoras que competem entre si pelo ponto focal em questão. Neste caso, persiste a presença dos entes estatais, mas começa a imperar uma lógica mais ligada aos incentivos de mercado enunciados por Cashore (idem), estimulando a concorrência entre diversas iniciativas, ainda que atreladas a órgãos de natureza pública, como nos exemplos listados do sistema de defesa de concorrência norte-americano e europeu.

Ao mirarmos o contexto privado de criação de regras, duas novas possibilidades se descortinam à nossa frente. No primeiro caso, onde tal contexto interage com mecanismos não baseados no mercado, obtemos como resultado mecanismos denominados pelos autores como (iii) criadores "focais" de padrões transnacionais, ou seja, instituições cuja missão é criar padrões e certificar cadeias e produtos, a partir de uma perspectiva externa.

Como exemplos destes criadores de padrões, temos a ISO (International Organization for Standardization) a IASB (International Accounting Standards Boards) e a IEC (International Eletrotechnical Comission) que, a despeito de constituírem importante referência no setor de regulação, diferenciam-se dos novos arranjos de 
governança na medida em que não estão inseridos na cadeia produtiva de determinados setores e nem são compostos por atores ligados a eles.

Por fim, no caso da interação entre o contexto institucional privado de criação de regras e mecanismos de seleção inseridos no mercado, é produzida a regulação transnacional engendrada por empresas privadas e pelo terceiro setor em arranjos institucionais que definem e aplicam standards para além do âmbito dos estados nacionais e das organizações intergovernamentais. Trata-se justamente da governança que é objeto deste trabalho e que afirma a articulação com os autores supracitados no que diz respeito à importância da adesão às regras para se legitimarem e na relevância do processo de adaptação aos mecanismos de mercado.

Como exemplo desta regulação, podemos citar desde a evolução de padrões de reprodução de audiovisual pelo próprio mercado ${ }^{7}$ até e as próprias iniciativas de regulação multistakeholder como as pioneiras Forest Stewardship Council (FSC) e Marine Stewardship Council (MSC), os Padrões de Responsabilidade Social Empresarial (RSE) e o próprio BSI-Bonsucro, sobre o qual nos debruçaremos mais adiante.

\footnotetext{
${ }^{7}$ Tal disputa foi protagonizada pela JVC contra a Sony no final do século XX, com a ascensão do VHS e reprisada no alvorecer do século XXI com a concorrência entre Sony e Toshiba, onde prevaleceu o Blue Ray
} 


\section{Quadro 3 - Tipologia para padrões de certificação}

\begin{tabular}{|c|c|c|c|}
\hline \multirow{4}{*}{$\begin{array}{c}\text { Mecanismo de } \\
\text { seleção }\end{array}$} & & \multicolumn{2}{|c|}{ Contexto institucional da criação da regra } \\
\hline & & Público & Privado \\
\hline & $\begin{array}{c}\text { Não baseado no } \\
\text { mercado }\end{array}$ & $\begin{array}{l}\text { (I) Produção de marco } \\
\text { regulatório através de acordos e } \\
\text { tratados internacionais; } \\
\text { Delegação a OIs e cooperação } \\
\text { regulatória transgovernamental } \\
\text { Exemplos: Protocolo de Quioto, } \\
\text { OIT (Organização Internacional } \\
\text { do Trabalho); FMI (Fundo } \\
\text { Monetário Internacional) }\end{array}$ & $\begin{array}{l}\text { (III) Criador “focal" de } \\
\text { padrões transnacionais } \\
\text { Exemplos: } \\
\text { (International Orgaization } \\
\text { for Standardization), IASB } \\
\text { (International Accounting } \\
\text { Standards Boards) e IEC } \\
\text { (International } \\
\text { Electrotechnical Comission) }\end{array}$ \\
\hline & $\begin{array}{l}\text { Baseado no } \\
\text { mercado }\end{array}$ & $\begin{array}{l}\text { (II) Órgãos públicos e/ou } \\
\text { agências } \\
\text { promovem standards de } \\
\text { alcance regional, nacional ou } \\
\text { bilateral que competem entre si } \\
\text { sem ponto focal } \\
\text { Exemplos: Sistema de } \\
\text { defesa daConcorrência (UE e } \\
\text { EUA), Codex Alimentarius }\end{array}$ & $\begin{array}{l}\text { (IV) Empresas, co- } \\
\text { regulação, firmas, ONGs e } \\
\text { arranjos institucionais } \\
\text { transnacionais produzem } \\
\text { órgãos que definem e } \\
\text { aplicam standards fora do } \\
\text { âmbito dos estados e OIs. } \\
\text { Exemplos: JVC x Sony } \\
\text { (videocassete); Sony X } \\
\text { Toshiba (Blue Ray); FSC } \\
\text { (Forest Stewardship } \\
\text { Council); MSC (Marine } \\
\text { Stewardship Council); RSE } \\
\text { (Padrões } \\
\text { Responsabilidade } \\
\text { Empresarial Social }\end{array}$ \\
\hline
\end{tabular}

Fonte: Büthe e Mattli (2011) apud Donadelli (2012)

Para compreender melhor o que leva que a disputa de dois padrões no interior de um determinado mercado alcance os graus de refinamento de uma iniciativa multistakeholder como aquelas que citamos, vale acessar o estudo de Nadvi e Wältring (2004), cujo quadro-resumo reproduzimos abaixo, como o quadro 4. Neste trabalho, os 
autores apresentam uma proposta de classificação das certificações, baseada nos conceitos de verificação e monitoramento.

Desta forma, as i) certificações por primeira parte seriam as mais simples, ou seja, aquelas em que o próprio ator promove a verificação e o monitoramento das regras e, por essa razão, sendo de mais fácil implementação, mas, em contrapartida, possuindo um baixo grau de legitimidade. No caso das ii) certificação por segunda parte, a tarefa de verificação e monitoramento caberia a outra parte, mas ainda interessada no processo, o que, de certa forma leva também a uma situação semelhante de fácil implementação e baixo grau de legitimidade.

Por fim, existem as iii) certificação de terceira parte, em que o ator divide a prerrogativa de verificação e de monitoramento com outros atores autônomos e independentes como auditores privados, ONGs, sindicatos, entre outros. Nesta modalidade, onde começam a aparecer critérios e indicadores a serem cumpridos, a implementação pode começar a ter um grau de intermediária a difícil, mas a legitimidade também alcança níveis de médios a altos.

Quadro 4 - Evolução dos padrões socioambientais de certificação

\begin{tabular}{|c|c|c|c|c|c|}
\hline GERAÇÃO & EXEMPLOS & ATORES & DRIVERS & $\begin{array}{l}\text { INFLUÊNCIA NO } \\
\text { COMÉRCIO } \\
\text { INTERNACIONAL }\end{array}$ & CERTIFICAÇÃO \\
\hline $\begin{array}{l}\text { Primeira: } \\
\text { Código de } \\
\text { Conduta de } \\
\text { empresas }\end{array}$ & $\begin{array}{l}\text { Nike, Reebook, } \\
\text { Karstadt (auto- } \\
\text { obrigação das } \\
\text { empresas junto } \\
\text { aos } \\
\text { fornecedores) }\end{array}$ & $\begin{array}{l}\text { Empresas e } \\
\text { fornecedores }\end{array}$ & $\begin{array}{l}\text { Empresas que } \\
\text { organizam e } \\
\text { lideram a } \\
\text { cadeia de } \\
\text { suprimentos }\end{array}$ & $\begin{array}{l}\text { Baixa, muitos } \\
\text { códigos de empresas } \\
\text { com foco em marcas } \\
\text { (consumidor). }\end{array}$ & $\begin{array}{c}\text { Certificação por } \\
\text { primeira parte } \\
\text { (fácil implementação; } \\
\text { baixa legitimidade) }\end{array}$ \\
\hline $\begin{array}{c}\text { Segunda: } \\
\text { Setores } \\
\text { definem } \\
\text { códigos e } \\
\text { selos. }\end{array}$ & $\begin{array}{l}\text { ICC, Eco-tex, } \\
\text { AVE }\end{array}$ & $\begin{array}{l}\text { Empresas, } \\
\text { associações } \\
\text { empresariais } \\
\text { e } \\
\text { fornecedores }\end{array}$ & $\begin{array}{l}\text { Associações } \\
\text { empresariais }\end{array}$ & $\begin{array}{l}\text { Baixa, com maior } \\
\text { influência a depender } \\
\text { do setor envolvido. }\end{array}$ & $\begin{array}{c}\text { Certificação por } \\
\text { segunda parte } \\
\text { (fácil implementação; } \\
\text { baixa legitimidade) }\end{array}$ \\
\hline
\end{tabular}




\begin{tabular}{|c|c|c|c|c|c|}
\hline $\begin{array}{c}\text { Terceira: } \\
\text { Empresas } \\
\text { definem } \\
\text { padrões } \\
\text { internacionais }\end{array}$ & ISO 14000 & $\begin{array}{c}\text { Entidades de } \\
\text { normatizaçã } \\
\text { o (ABNT, } \\
\text { ISO) }\end{array}$ & $\begin{array}{c}\text { Empresas e } \\
\text { entidades de } \\
\text { normatização }\end{array}$ & $\begin{array}{c}\text { Média, com } \\
\text { obrigações que } \\
\text { reorientam os fluxos } \\
\text { de comércio. }\end{array}$ & $\begin{array}{l}\text { Certificação por } \\
\text { terceira parte } \\
\text { (implementação } \\
\text { intermediária; } \\
\text { alta legitimidade) }\end{array}$ \\
\hline $\begin{array}{c}\text { Quarta: } \\
\text { Empresas e } \\
\text { ONGs } \\
\text { definem selos } \\
\text { específicos } \\
\text { para o setor }\end{array}$ & $\begin{array}{c}\text { Transfair, FSC, } \\
\text { Rugmark, MSC } \\
\text { - parceria entre } \\
\text { empresas e } \\
\text { ONGs com } \\
\text { inclusão da } \\
\text { sociedade civil }\end{array}$ & $\begin{array}{l}\text { ONGs, } \\
\text { associações } \\
\text { religiosas, } \\
\text { sindicatos, } \\
\text { distribuidore } \\
\text { s, minorias } \\
\text { étnicas e } \\
\text { sociais }\end{array}$ & $\begin{array}{c}\text { ONGs e } \\
\text { movimentos } \\
\text { sociais }\end{array}$ & $\begin{array}{l}\text { Alta, porque define } \\
\text { acesso a mercados e } \\
\text { organiza ações de } \\
\text { ONGs, empresas e } \\
\text { distribuidoras. }\end{array}$ & $\begin{array}{l}\text { Certificação por } \\
\text { terceira parte } \\
\text { (implementação } \\
\text { difícil; legitimidade } \\
\text { sujeita a negociação } \\
\text { constante) }\end{array}$ \\
\hline $\begin{array}{l}\text { Quinta: } \\
\text { Definição } \\
\text { genérica de } \\
\text { standards }\end{array}$ & $\begin{array}{l}\text { SA8000, FLA, } \\
\text { ETI: } \\
\text { harmonização } \\
\text { de códigos e } \\
\text { selos para dar } \\
\text { legitimidade, } \\
\text { transparência e } \\
\text { rastreabilidade. }\end{array}$ & $\begin{array}{l}\text { ONGs, } \\
\text { movimentos } \\
\text { sociais, } \\
\text { sindicatos, } \\
\text { entidades } \\
\text { certificadora } \\
\text { s, governos }\end{array}$ & $\begin{array}{l}\text { Setor público, } \\
\text { ONGs, } \\
\text { sindicatos e } \\
\text { movimentos } \\
\text { sociais }\end{array}$ & $\begin{array}{l}\text { Alta, porque promove } \\
\text { harmonização e } \\
\text { consenso mínimo } \\
\text { entre os stakeholders }\end{array}$ & $\begin{array}{c}\text { Certificação por } \\
\text { terceira parte } \\
\text { (implementação } \\
\text { difícil; legitimidade } \\
\text { sujeita a negociação } \\
\text { constante) }\end{array}$ \\
\hline
\end{tabular}

Fonte: Nadvi e Wältring (2004) traduzida pelo autor.

Com base nas modalidades de certificação, Nadvi e Wältring definem cinco gerações de padrões socioambientais, desdobrando cada uma delas em características, 
exemplos, atores, drivers e a maneira como influenciam - ou o grau de influência - no comércio internacional.

A primeira geração, calcada em certificações de primeira parte, diz respeito a códigos de conduta empresariais, tendo como atores apenas empresas e fornecedores. Nesse caso, quem promove a certificação são as próprias empresas que lideram e organizam a cadeia produtiva e a influência desta ação no comércio internacional é baixa, restringindo seu foco em marcas, como por exemplo a Nike, a Reebook e a Karstadt

Na segunda geração, por sua vez amparada em certificações de segunda parte, observa-se a definição de selos e códigos por parte das empresas e fornecedores capitaneados por associações comerciais e de defesa de interesses. Nesse sentido, a influência no comércio internacional continua a ser baixa, mas pode alcançar níveis mais altos a depender do setor em questão, como o têxtil, por exemplo, no caso listado da Eco-tex.

Já a terceira geração envolve a adesão de empresas a padrões internacionais de excelência, ou seja, o cumprimento de determinadas normas ou regulamentos que lhes confere um determinado status. Assim, os únicos atores - e consequentemente promotores das certificações - são as entidades normatizadoras como a ISO ou a ABNT, as quais Büthe e Mattli (idem) já haviam definido como criadoras de padrões focais.

Neste caso, a influência no comércio internacional já passa a ser mediana, na medida em que o status conferido pode reorientar os fluxos comerciais em favor da empresa - ou contrariamente, no caso de ela não atender aos padrões - e as certificações são de terceira parte, com uma implementação de grau de dificuldade intermediário e alta legitimidade.

Para a quarta geração, já é possível afirmar que começa a aparecer a regulação compartilhada por ONGs e empresas privadas com vistas à definição de selos e certificados específicos para determinados setores. Nesta modalidade de certificação, a direção é compartilhada entre os atores e a certificação é de terceira geração com difícil implementação e uma legitimidade constantemente sujeita a negociações no interior do setor ou do arranjo. Sua influência no comércio internacional já é alta porque o compliance com as regras define acesso a mercados para as empresas e determina o comportamento e as ações entidades do terceiro setor e da sociedade civil, conforme podemos observar nos exemplos das iniciativas multistakeholder como os já citados 
Forest Stewardship Council (FSC) e Marine Stewardship Council (MSC) e novamente o próprio BSI-Bonsucro.

Por fim, a quinta geração onde diversos tipos de atores - sejam eles ONGs, sindicatos, movimentos sociais - comandam eles próprios a harmonização de códigos e selos genéricos para dotá-los de transparência, rastreabilidade e legitimidade. Trata-se igualmente de uma certificação de terceira geração com difícil implementação e uma legitimidade constantemente sujeita a negociações, cuja influência no comércio internacional é alta por promover a harmonização e um consenso mínimo entre os stakeholders como na Fair Labor Association (FLA) e na Ethical Trading Initiative (ETI).

Como podemos observar, à medida que as iniciativas de certificação vão evoluindo e ganhando complexidade, a dificuldade de implementação aumenta, mas a influência no comércio internacional e a legitimidade da iniciativa galgam patamares cada vez mais elevados, ainda que no caso das denominadas quarta e quinta gerações, a legitimidade esteja sujeita a constantes negociações pelas partes envolvidas.

Diante disso, é preciso compreender as características ligadas diretamente às certificações socioambientais e os setores que buscaram se organizar em torno de uma governança semelhante a fim de compreender os aspectos específicos desses arranjos, notadamente no que diz respeito a sua articulação com as determinadas cadeias produtivas.

\subsection{Cadeias globais e a certificação socioambiental}

Em primeiro lugar, é importante enfatizar que estes arranjos de certificação têm se disseminado em diversos setores produtivos, embora as questões ambientais ligadas à agricultura tenham sido aquelas em que tal dinâmica ganhou maior preeminência nos últimos anos - sobretudo se levarmos em conta as dificuldades dos estados em lidar sozinhos com esta complexa questão.

Assim, cabe destacar, em primeiro lugar, a afirmação de Abdala (2007) dando conta de que:

“o gerenciamento e a resolução de problemas mundiais relacionados com politicas ambientais globais têm se deslocado da esfera estrita do aparelho do Estado para o escopo ampliado da comunidade mundial, dando espaço aos chamados novos atores: os setores privados e as 
organizações não-governamentais, sindicais, os movimentos ecológicos e sociais, entre outros com certa capacidade de influir na opinião pública e nas decisões de governo, além de organismos internacionais e redes transnacionais."

(Abdala, 2007, pp. 46)

Conforme já apontamos, as certificações socioambientais no âmbito dos biocombustíveis, na qual está inserido nosso estudo de caso, evoluíram, principalmente, a partir de iniciativas semelhantes levadas a cabo nos setores agrícolas e florestais, denominadas roundtables, cujas raízes remontam ao século $\mathrm{XX}$, mais precisamente em seu quarto final. (Perosa, 2012).

A iniciativa pioneira neste âmbito foi a Forest Stewardship Council (FSC), cuja origem remonta aos anos $1990{ }^{\prime} \mathrm{s}^{8}$, tendo sido seguida por outras na área da piscicultura (Berkes, 1985; Cordell \& Mckean, 1985) e dos recursos hídricos (Fortmann \& Roe, 1985; Wade, 1985; Lam, 1998), abrindo caminho para cadeias produtivas como as de soja (Rodrigues, 2013), palma (Silva-Castañeda, 2012), cana-de-açúcar, entre outras.

Em todos estes arranjos, é digno de nota o papel da WWF - World Wide Fund for Nature - que atuou como fundadora e buscou reunir os maiores players (produtores e consumidores, além de intermediários e ONGs) das determinadas cadeias para que se comprometessem com padrões para além de sua zona de conforto. (Fortin, 2013)

Nesse sentido, a reunião destes atores - diversos em sua natureza, mas comuns no produto a ser regulado - permitiu que se engendrasse um esquema com grande diversidade, mas com uma forte preocupação acerca da legitimidade, lastreada nos princípios de inclusão, transparência e responsividade. Para tanto, garantiram-se mecanismos de facilitação do acesso de entidades de baixo orçamento ou de países em desenvolvimento, a disponibilização pública das avaliações e auditorias realizadas. (Bernstein and Cashore, 2007).

De acordo com (Hatanaka and Busch, 2008), uma vez que tais arranjos estejam estabelecidos, seu funcionamento ocorre tanto por meio de selos que comunicam os consumidores sobre os padrões de sustentabilidade do produto como por meio da busca da integração dos standards na legislação estatal de mercado, embora sem qualquer tipo de envolvimento direto dos estados.

\footnotetext{
${ }^{8}$ Há estudos interessantes produzidos sobre o tema por Banana \& William, 2000; Ghate \& Nagendra, 2005; Chatre \& Agrawal, 2008 e Donadelli (2011).
} 
Dessa forma, conforme já pontuamos, a governança de tais arranjos é exclusivamente ligada ao âmbito privado, situando-se de acordo com o trabalho de Williamson (1996), em um tipo híbrido entre a desregulamentação do mercado e a hierarquia fechada das firmas a la Coase $^{9}$.

\section{Quadro 5 - Tipos de governança e suas características}

\begin{tabular}{|c|c|}
\hline Tipos de Governança & Características Básicas \\
\hline Mercado & $\begin{array}{l}\text { a) Ativo não específico; } \\
\text { b) Não existem esforços para sustentar a relação; } \\
\text { c) Partes consultam apenas a experiência; } \\
\text { d) Existe pouca necessidade de controle administrativo, } \\
\text { o que significa que os contratos são cumpridos sem } \\
\text { grandes riscos de oportunismo; } \\
\text { e) Pode ensejar a resolução de conflitos via judiciário } \\
\text { Exemplo: comprar qualquer alimento de subsistência } \\
\text { numa mercearia de bairro, ignorando qualquer tipo de } \\
\text { marca e reputação. }\end{array}$ \\
\hline Hierárquica (firma) & $\begin{array}{l}\text { a) Grande impacto das falhas de mercado, a ponto de } \\
\text { prejudicar o cumprimento de contratos, podendo ser } \\
\text { alvos de ações oportunistas; } \\
\text { b) Propício ao risco de influência e existe a necessidade } \\
\text { de coordenação e imposição da autoridade política. } \\
\text { Exemplo: integração vertical de firmas. }\end{array}$ \\
\hline Híbrida & $\begin{array}{l}\text { a) É necessária a coordenação dos indivíduos dentro de } \\
\text { sistemas de incentivos e contratos que possam } \\
\text { minorar os comportamentos oportunistas, reduzindo } \\
\text { os custos de transação em ambientes de informação } \\
\text { assimétrica. } \\
\text { Exemplo: regulação, franquias, redes. }\end{array}$ \\
\hline
\end{tabular}

Fonte: Willianson (1996).

\footnotetext{
${ }^{9}$ Richard Coase (1937), autor da teoria da firma, de quem Williamson foi o grande continuador teórico.
} 
Esta governança híbrida, delimitada no quadro 5 acima, tem como característica central a coordenação dos atores auto-interessados por meio de um sistema de incentivos e contratos com vistas a minorar os comportamentos oportunistas e, ao mesmo tempo, reduzindo os custos de informação em ambientes de informação assimétrica.

Dessa forma, por meio desse tipo de governança, diversos atores em diferentes setores acabaram por criar arranjos de certificação socioambiental. Diante da diversidade desses setores que, é necessário compreender o que a literatura identifica como eixos estruturantes da discussão destes arranjos. Conforme apontado por autores como Büthe (2010), Donadelli (2011) e Rodrigues (2013), o campo de análise é multidisciplinar e vinculado a questões de: i) motivações; ii) compliance e iii) efetividade.

No campo das motivações que determinaram a constituição destes arranjos, existem alguns trabalhos significativos. Uma primeira possibilidade seria a explicação do o déficit de governança apontado por Gerrefi \& Mayer (2005). Para estes autores, a ausência de instituições centralizadas associada à voracidade das empresas pelo lucro, sem qualquer preocupação maior com o meio ambiente e as condições de seus trabalhadores, ensejou a criação desse movimento por parte do terceiro setor.

Se esta explicação tem o mérito de apontar o cenário em que tais iniciativas vêm à luz, é preciso dizer que ela não dá conta de informar os mecanismos que levam os atores envolvidos a buscar engendrá-los. Nesse sentido, a tese de Bartley (2007) pugna pela necessidade de que se observe os mecanismos de mercado e de mobilização da sociedade civil como incentivos de ordem positiva e negativa para alcançar a cooperação.

Tais incentivos, quando positivos, podem estar ligados a uma estratégia de diferenciação pela reputação positiva que a adesão às iniciativas pode proporcionar. Já no caso dos incentivos ditos negativos, o autor se refere ao se convencionou chamar de naming and shaming, ou seja, a associação de empresas a práticas reprováveis no campo socioambiental e sua posterior divulgação.

Em consonância com as forças do mercado propriamente ditas, Bartley afirma que determinados estados, ONGs e conglomerados empresariais teriam buscado nestes mecanismos a solução de determinados impasses que o sistema multilateral de comércio, liderado pela Organização Mundial do Comércio (OMC), não havia sido capaz de fazer avançar. Tal assertiva nos leva, contudo, à questão de por qual razão 
determinados atores se comprometeriam com arranjos criados ou levados a cabo por outros atores, sem determinado tipo de contrapartida mais factível em termos de lucros.

Neste diapasão teórico, o trabalho de Margolis \& Walsh (2001) aponta que o compliance dos produtores e empresas com tais arranjos está longe de ser um mecanismo irracional ou desinteressado. Na realidade, a adesão a estes arranjos seria fruto de um cálculo racional e auto-interessado visando ganhos de três naturezas distintas: reputacional, informacional e competitiva, conforme apresentado abaixo, no quadro 6.

Quadro 6 - Ganhos obtidos no processo de regulação (Margolis e Walsh, 2001)

\begin{tabular}{|c|c|c|}
\hline Ganhos Reputacionais & Ganhos Informacionais & Ganhos Competitivos \\
\hline $\begin{array}{l}\text { Diferenciação de empresas } \\
\text { de um mesmo setor e } \\
\text { exclusão de free-riders no } \\
\text { processo }\end{array}$ & $\begin{array}{l}\text { Diminuição dos problemas } \\
\text { de assimetria de informação } \\
\text { para os consumidores }\end{array}$ & $\begin{array}{c}\text { Aumento da } \\
\text { competitividade no setor } \\
\text { com ganhos e custos } \\
\text { ligados ao compliance. }\end{array}$ \\
\hline
\end{tabular}

Fonte: elaborado pelo autor com base em Margolis e Walsh (2001).

Assim, o primeiro tipo de ganho que os atores visam seria justamente o ganho reputacional, ou seja, a busca por se apresentar como um ente diferenciado no mesmo setor, excluindo possíveis free-riders, isto é, o "carona" que buscaria apenas receber os benefícios reputacionais, sem investir no cumprimento das regras associadas ao arranjo de certificação. Uma segunda forma de ganho seriam os ganhos informacionais, os quais visariam reduzir os problemas de informação assimétrica com relação aos processos de produção e manejo por parte dos consumidores, cuja complexidade das atuais cadeias produtivas ampliou sobremaneira.

Por fim, um terceiro conjunto de ganhos seria o de ganhos competitivos que determinaria "prêmios" para aqueles que aderissem aos arranjos e imporiam custos àquelas que ainda não se comprometeram com as regras do esquema de certificação, diferenciando o acesso a determinados mercados.

Outra explicação possível para compreender o compliance aos esquemas de certificação para além dos ganhos da teoria de Margolis \& Walsh é a contribuição de Hommel (2010) que identifica outros mecanismos, atribuindo um papel ativo ora aos 
consumidores, ora aos produtores. No primeiro caso, a explicação recai na articulação dos compradores por produtos sócio-ambientalmente mais responsáveis, criando uma espécie de demanda por certificação.

Já as teorias ligadas à ação dos produtores trazem duas explicações distintas. A primeira delas seria a chamada "teoria de barreira à entrada", a qual afirma que os produtores se articulariam voluntariamente em torno dos arranjos de certificação para criar constrangimentos à entrada de novos atores no mercado daquele determinado setor, beneficiando aqueles que já estão comprometidos com as práticas recomendadas. Já a segunda teoria, no caso a "teoria da prevenção", afirma que os membros dos esquemas de certificação "amarrariam suas mãos" em regulações mais simples a fim de se antecipar a regulações estatais, cujo conteúdo poderia acabar sendo ainda mais draconiano para as empresas do setor.

Em ambos os casos é preciso ter em mente que tais teorias seriam perfeitamente adequadas para certificações estanques, ou seja, aquelas cujas normas seriam combinadas apenas previamente, sem qualquer mudança posterior. No caso de certificações socioambientais multistakeholder, como as roundtables agrícolas, elas fornecem apenas parte da explicação, uma vez que estas certificações estão em constante processo de legitimação, como apontaram Nadvi e Wältring.

\subsection{As limitações das certificações}

Se as teorias para demonstrar o compliance dos atores carecem de um maior poder explicativo para os casos mais complexos, a questão da efetividade dos arranjos de certificação é ainda mais controversa, na medida em que as relações de causalidade acerca do impacto destes sobre as medidas que pretendem regular são bastante difíceis de ser verificadas.

Nesse sentido, alguns autores apontam para uma visão menos pessimista do alcance de tais iniciativas, como o trabalho de Potoski e Prakash (2005), em que eles afirmam a contribuição dos arranjos de certificação para melhorar as práticas nos setores que pretendem regular bem como na sociedade como um todo, por meio de uma observação dos setores antes e depois da regulação. Contudo, é importante ressaltar que o grande problema nesse tipo de observação é a dificuldade de se atribuir tal efeito unicamente aos arranjos de certificação, sendo impossível determinar sua real 
contribuição para o fenômeno e aquela advinda de outras variáveis que não se pode controlar.

Outra explicação mais acurada vem do trabalho de Gereffi \& Mayer (2010), o qual ressalta que a efetividade de tais iniciativas seria, nesse sentido, função específica de quatro variáveis: i) a estrutura da cadeia de produção em questão e o impacto da regulação em seus membros; ii) a dependência da marca, ou seja, o quanto a empresa depende de sua reputação junto ao consumidor final; iii) a possibilidade de organização de pressão por parte de consumidores e/ou ativistas junto a esta cadeia e iv) o alinhamento entre as preocupações comerciais e os interesses sócio-ambientais a serem regulados

Nesses estudos, contudo, o problema da causalidade permanece, sendo difícil distinguir o que é fruto da certificação e o que adviria de outros fatores, comprometendo os estudos que buscam limitar a explicação de tais arranjos apenas à dimensão da efetividade.

Diante dessa dificuldade, muitos autores mostram-se bastante descrentes sobre a capacidade destes arranjos em produzir quaisquer mudanças efetivas no comportamento dos atores. Os trabalhos de King \& Lenox (2000) e Darnal \& Sides (2008) chegam a apontar uma conduta pior dos atores envolvidos em esquemas de certificação perante as regras que dizem se comprometer do que aqueles que não o fazem, enquanto Krawiec (2003) denunciaria a utilização destes mecanismos como mera forma de autopromoção no ambiente corporativo.

Além disso, há trabalhos como os de Foster, Wang \& Keeton (2008) que alegam não ver diferença entre aqueles que integram ou não esquemas de certificação, no que tange à observação de padrões socioambientais mais elevados. É curioso que, ainda que não haja consenso sobre a efetividade dos arranjos de certificação, as limitações destas iniciativas são exploradas de maneira bastante similar na maioria dos trabalhos.

A primeira delas diz respeito à endogenia destes mecanismos, ou seja, o fato de que as próprias entidades que engendram os critérios de regulação seriam aquelas que obrigatoriamente terão de observar essas regras.

Este desenho acaba por colocar em xeque o quanto elas de fato buscam uma agenda ambiciosa ou apenas se comprometem com aquilo que já realizam em suas práticas habituais. Assim, para Downs, Rocke e Basroom (1996), a endogeneidade intrínseca a tais mecanismos faria com que os padrões adotados fossem bastante 
semelhantes às preferências dos atores envolvidos, deixando de lado seus reais objetivos de cooperação em detrimento de seus próprios objetivos.

Além disso, um segundo problema relacionado a tais iniciativas é a questão da captura regulatória. De acordo com o artigo seminal de Stigler (1971) sobre o tema, a captura regulatória seria um tipo de falha de regulação em que as regras, supostamente criadas para favorecer o interesse público, acabam por favorecer determinados grupos em detrimentos dos demais. $\mathrm{O}$ autor prossegue afirmando que tal favorecimento pode se materializar de diversas formas como subsídios diretos em dinheiro, controle de entrada de novos concorrentes no mercado, medidas que limitem a produção de bens substitutos e fixação de preços.

O fenômeno da captura ganha contornos ainda mais vivos quando registramos a diferença entre a "captura de decisões" e a "captura de informações". Enquanto a primeira diz respeito à ideia de moldar as regulações ao melhor resultado para os determinados grupos por meio de influência direta nas esferas de decisão, a segunda conecta-se com a assimetria de informação que traria vantagens no decorrer do processo de regulação

Dessa forma, essa suscetibilidade aos "interesses especiais" é tributária, por um lado, de processos pouco inclusivos e fechados no seio de tais mecanismos e, por outro, da baixa capacidade de pressão e monitoramento por parte dos atores que defendem demandas de caráter mais amplo, implicando numa regulação que favoreceria apenas a determinados grupos em detrimento do interesse comum.

Nesse sentido, para Gonçalves (2014), alguns efeitos bastante evidentes da captura regulatória são: i) a redistribuição de recursos (nas esferas política e econômica) em favor de um grupo e em detrimento do bem-estar da sociedade como um todo; ii) o impacto desfavorável com relação à eficiência econômica, motivado por distorções na concorrência e pelos próprios custos de realização e de proteção ao fenômeno da captura.

Como se vê, trata-se de um grave problema no seio de esquemas de certificação que precisa ser evitado, a fim de não distorcer os reais objetivos das iniciativas. Para minorar tais efeitos, Schepers (2009) faz uma crítica contundente dos modelos atuais e enumera sete instrumentos que trariam mais legitimidade aos arranjos de governança privada frente a tais limitações: i) transparência; ii) construção de padrões rigorosos; iii) certificação por terceira parte independente; iv) processo inclusivo e negociado de criação de padrões; v) índices sociais publicados por estados ou organizações 
internacionais; vi) certificação do setor a que pertence o arranjo e vii) esforço de natureza global para a construção de tais padrões.

Estas características dependem fundamentalmente da capacidade de articulação dos atores envolvidos. Nesse sentido, fica patente por esta revisão bibliográfica que a maioria dos problemas e limitações dos arranjos de certificação guarda relação com a coordenação dos interesses dos atores em arranjos coletivos, superando a esfera do autointeresse e buscando a cooperação para superar problemas comuns.

Para tanto, será necessário compreender melhor os fundamentos da articulação da ação coletiva nestes arranjos, o que buscaremos fazer mais adiante neste trabalho. No entanto, antes de enveredar pela análise da questão de ação coletiva propriamente dita, é importante conhecermos nosso universo mais amplo de análise. Por esta razão, o próximo capítulo buscará compreender o setor sucroalcooleiro como um todo, abordando o funcionamento da cadeia de cana-de-açúcar, os mercados internacionais de açúcar e etanol, seus impactos sócio-ambientais e as diversas iniciativas de certificação nestes dois mercados que visam minorar tais questões. 


\section{CAPÍTULO 2: A CADEIA DO AÇÚCAR E DO ETANOL DE CANA}

\subsection{O setor sucroalcooleiro: breve histórico e características}

A cana-de-açúcar (Saccharum sp) é uma planta cuja domesticação e cultivo remontam aos anos 6.000 a.C., na Nova Guiné, e cuja introdução na Europa se deu por meio dos árabes ainda no primeiro milênio da Era Cristã.

Posteriormente, foi trazida à América pelos ibéricos e, na América Portuguesa mais precisamente no território que viria a ser o Brasil - a cana foi introduzida ainda durante o século XVI, tornando-se o principal produto dos tempos coloniais e encontrando as condições geográficas ideais para fazer do país, ainda atualmente, o maior produtor mundial do insumo.

Por meio da observação da Figura 2, é possível perceber que o moderno funcionamento de uma usina de cana passa por diversas etapas a fim de obter os subprodutos que orientam essa produção. Em primeiro lugar, a cana in natura passa por um processo de moagem que separa o caldo do bagaço, sendo que este último segue para as caldeiras. Já o caldo resultante passa por um duplo processo de tratamento químico (coagulação, floculação e precipitação de impurezas) e filtração, cujo insumo é exposto a dois processos distintos, enquanto o subproduto chamado torta de filtro transforma-se em adubo.

No primeiro processo, seguem-se as etapas de evaporação, cozimento, centrifugação - donde se obtém o melado - e secagem, que, concluídas, levará à produção de açúcar. Já o processo concomitante envolve a fermentação do caldo sozinho ou junto ao melado -, a destilação (que libera a vinhaça) e a retificação que leva à produção de etanol hidratado.

Por meio da desidratação do etanol hidratado, é possível obter outro tipo de etanol - o anidro - sendo ambos utilizados como combustíveis. Enquanto o primeiro é utilizado sozinho, quando abastecemos o carro com etanol, o segundo mistura-se à gasolina em proporções estabelecidas por lei para economizar o combustível fóssil e, ao mesmo tempo, diminuir seus efeitos nocivos ao meio ambiente como a poluição do ar. 


\section{Figura 2 - Processo de produção em uma usina de cana-de-açúcar}

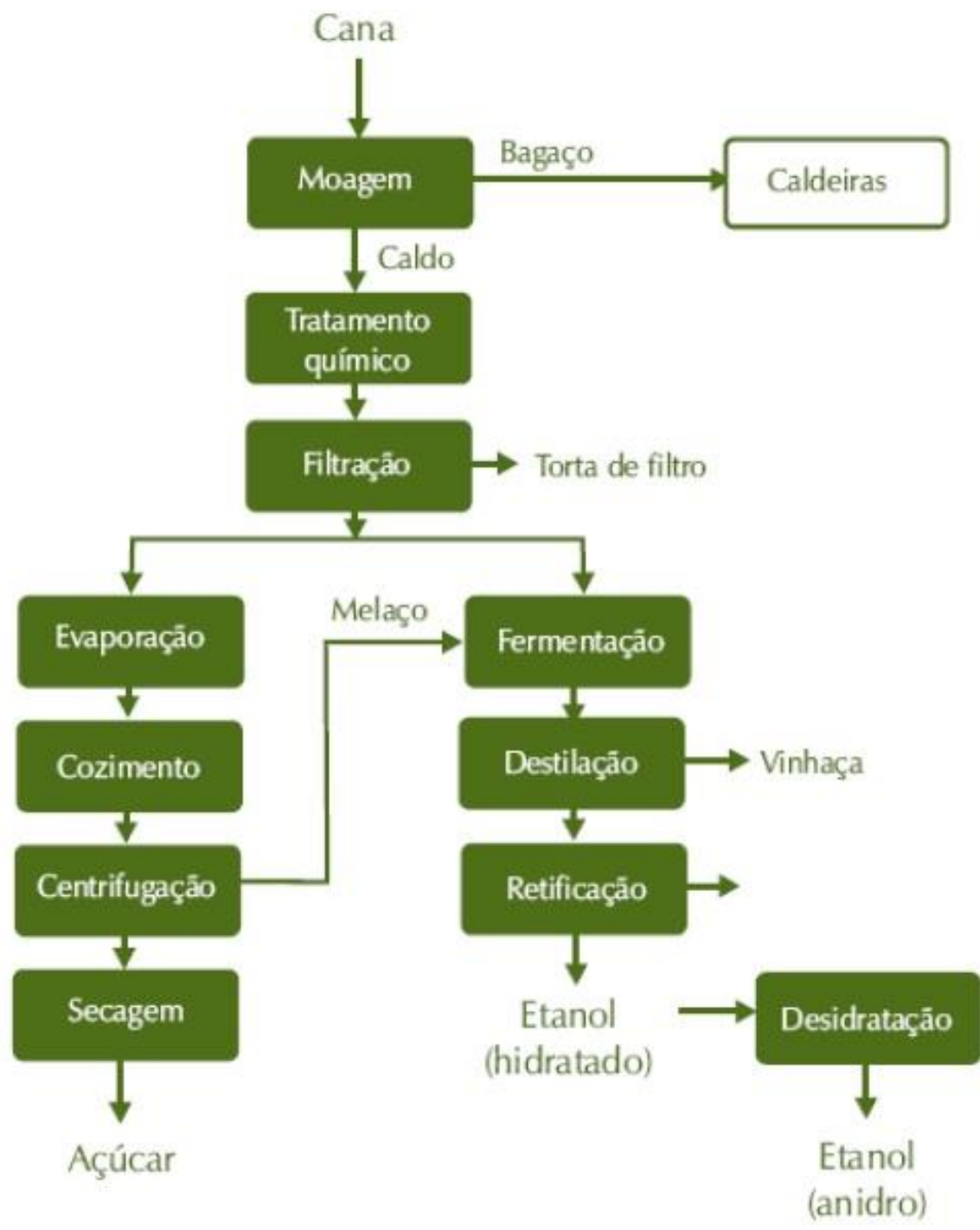

Fonte: BNDES (2008)

A produção na usina demonstra que os processos de produção entre os dois principais insumos - açúcar e etanol - são, em certa medida, interdependentes, o que determina a prática comum de alternar a produção entre um e outro mediante os preços mais ou menos vantajosos do comércio interno e internacional

Além do açúcar e do etanol, destinados respectivamente à indústria alimentícia e ao setor energético, cabe esclarecer que as usinas hoje produzem uma série de outros subprodutos, cuja utilização vem se ampliando para as mais diversas destinações. No esquema apresentado pela Figura 3, Olivério (2003) dispõe cada um dos subprodutos 
oriundos da cana-de-açúcar junto a seus respectivos usos e adaptações, oferecendo um quadro bastante interessante no que tange ao ciclo produtivo desta planta.

\section{Figura 3 - Subprodutos da cana-de-açúcar}

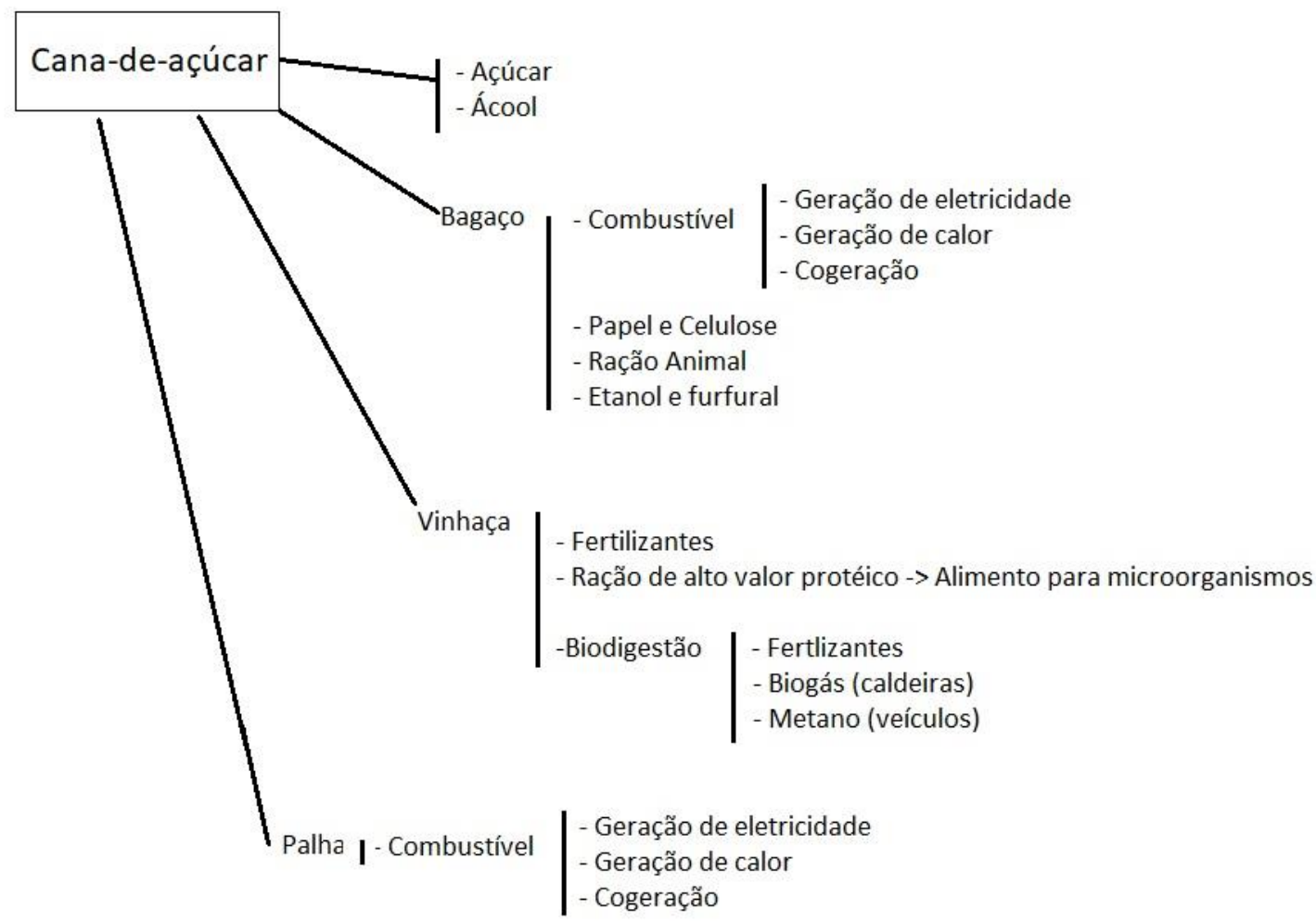

Fonte: Olivério, 2003, adaptado pelo autor

Em primeiro lugar, podemos observar que, a partir da cana-de-açúcar, são obtidos cinco principais subprodutos: o açúcar, o etanol, o bagaço, a vinhaça e a palha. Se há pouco tempo apenas o açúcar e o etanol eram economicamente explorados, atualmente podemos obter combustível, papel e ração animal do bagaço; fertilizantes, ração, biogás e metano da vinhaça e combustível via eletricidade e calor da palha.

Nesse sentido, o aproveitamento da matéria-prima é praticamente total e o ciclo produtivo da espécie é de seis anos, necessitando de um verdadeiro complexo agroindustrial para que a síntese de tais insumos ocorra, seja armazenada, processada e alcance os mercados consumidores intermediários e finais.

Assim, ao observarmos a Figura 4 oriunda do trabalho de Peixoto (2010), fica claro que a cadeia de produção da cana-de-açúcar conta com diversas etapas como a 
produção, o transporte, a armazenagem, o processamento e novamente o transporte para o escoamento da produção. Faz-se mister ter em mente que cada uma dessas etapas gera impactos e traz custos nos aspectos sociais e ambientais, seja por meio da mão-de-obra precária no plantio, produção e colheita do insumo, seja pelos impactos ambientais das queimadas ou do transporte essencialmente rodoviário ${ }^{10}$, tanto na primeira como na segunda etapa. (Peixoto, idem).

\section{Figura 4 - Cadeia produtiva da cana-de-açúcar}

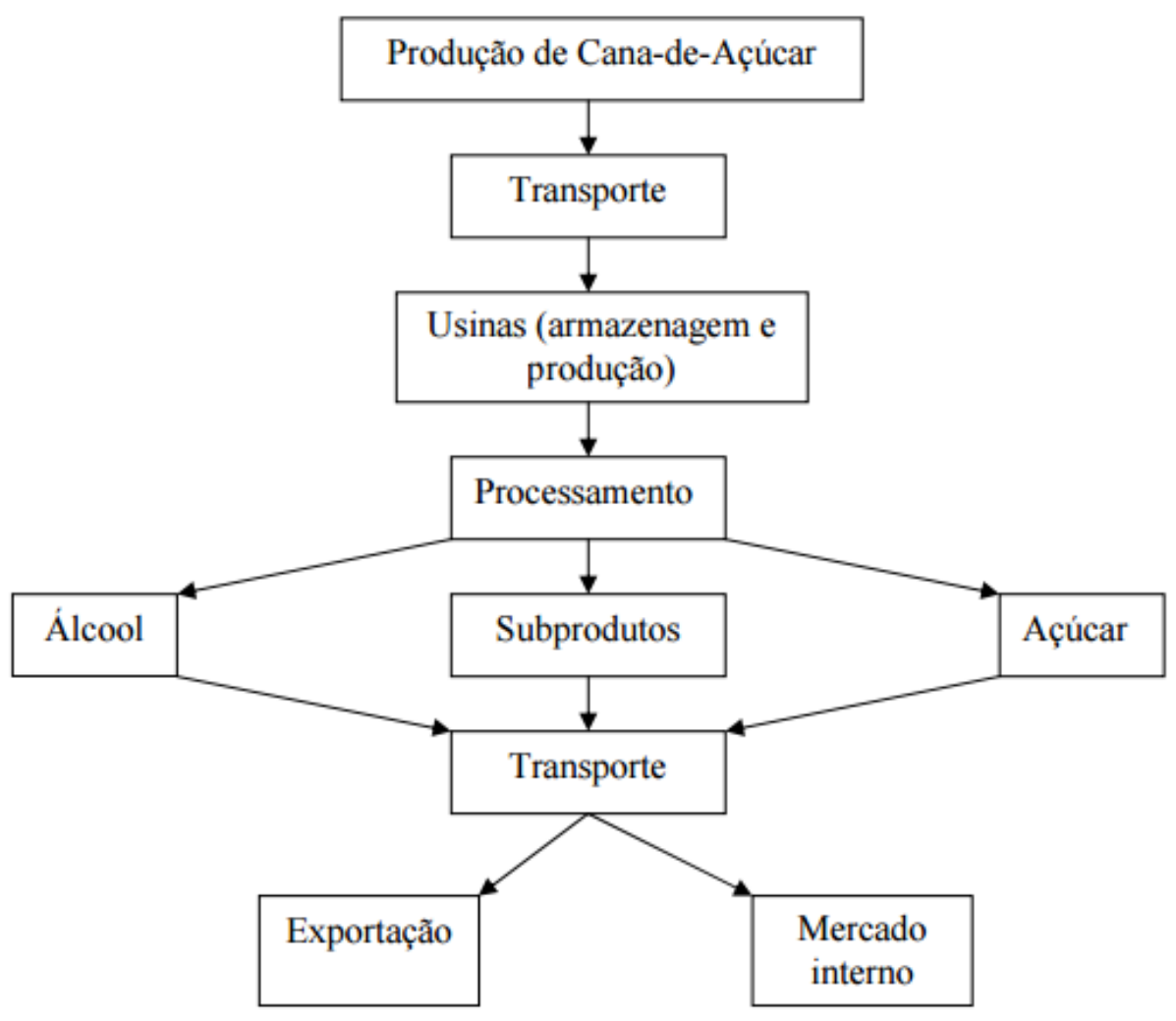

Fonte: Copersucar (2010) apud Peixoto (2010).

Diante desses impactos, é preciso ter em mente qual a envergadura do mercado de cana-de-açúcar em nível mundial. Para tanto, é fundamental conhecer alguns números do setor no geral e especificamente dos principais subprodutos - o açúcar e o

10 A despeito de haver algumas exceções em que o transporte na cadeia de cana se dá por meio de hidrovias, a maior parte ainda é efetuada por meio do modal rodoviário, com a utilização de caminhões, treminhões e rodotrens, constituindo um impacto negativo no balanço energético da cultura. 
etanol - a fim de compreender o quadro geral do mercado internacional de cana-deaçúcar.

\subsection{O mercado internacional de cana-de-açúcar}

O mercado internacional de cana-de-açúcar detém dados produtivos bastante impressionantes. De acordo com dados do Departamento de Estatística da FAO$\mathrm{ONU}^{11}$, no último ano consolidado de 2015 , foram produzidos 1.877 .105 milhões de toneladas de cana-de-açúcar no mundo todo.

O Brasil ocupa, como já afirmamos, a primeira colocação no que diz respeito à produção de cana com 739.267 milhões de toneladas. A segunda colocada, a Índia, não alcança sequer metade desse número com 341.200 milhões de toneladas, seguida por países com produções ainda mais modestas como China (125.536 mil/ton), Tailândia (100.096 mil/ton), Paquistão (63.750 mil/ton), México (61.282 mil/ton), Colômbia (34.876 mil/ton), Indonésia (33.700 mil/ton , Filipinas (31.874 mil/ton) e Estados Unidos da América (27.096 mil/ton).

Tabela 1 - Produção Mundial de cana-de-açúcar por país (2015)

\begin{tabular}{lc}
\hline País produtor & Produção em mil ton \\
\hline & \\
Brasil & 739.267 \\
Índia & 341.200 \\
China & 125.536 \\
Tailândia & 100.096 \\
Paquistão & 63.750 \\
México & 61.182 \\
Colômbia & 34.876 \\
Indonésia & 33.700 \\
\hline
\end{tabular}

\footnotetext{
${ }^{11}$ Da sigla em inglês "Food and Agrocultural Organization", a Organização das Nações Unidas para Alimentação e a Agricultura é uma agência especializada do sistema ONU que trabalha com as questões da segurança alimentar e do desenvolvimento agrícola, que conta atualmente com 194 países membros e 78 escritórios nacionais.
} 


\begin{tabular}{ll}
\hline Filipinas & 31.874 \\
Estados Unidos da América & 27.096 \\
\hline
\end{tabular}

Fonte: FAO-ONU (2015)

Diante de tais números, cabe observarmos mais atentamente os mercados internacionais de açúcar e de etanol, analisando os players envolvidos e a participação de cada um deles, a fim de compreender sua dinâmica e a influência que cada um possui no setor sucroalcooleiro em escala mundial.

Açúcar

O mercado internacional de açúcar remonta ao período do Renascimento e hoje é um dos maiores do mundo, sendo que a última safra consolidada de 2015/2016 produziu, de acordo com dados do Departamento de Agricultura dos Estados Unidos da América (USDA), nada menos que 171.799 mil toneladas de açúcar. A origem dessa produção é bastante diversificada, embora apenas Brasil e Índia detenham mais de um terço da produção do alimento - com $20,3 \%$ e $16,6 \%$ da produção, respectivamente seguidos por União Europeia, Tailândia, China, EUA, México, Paquistão e diversos outros países com produção inferior a 3\%, conforme o gráfico 1 abaixo:

\section{Gráfico 1 - Produção Internacional de açúcar por país - Safra 2015/2016}

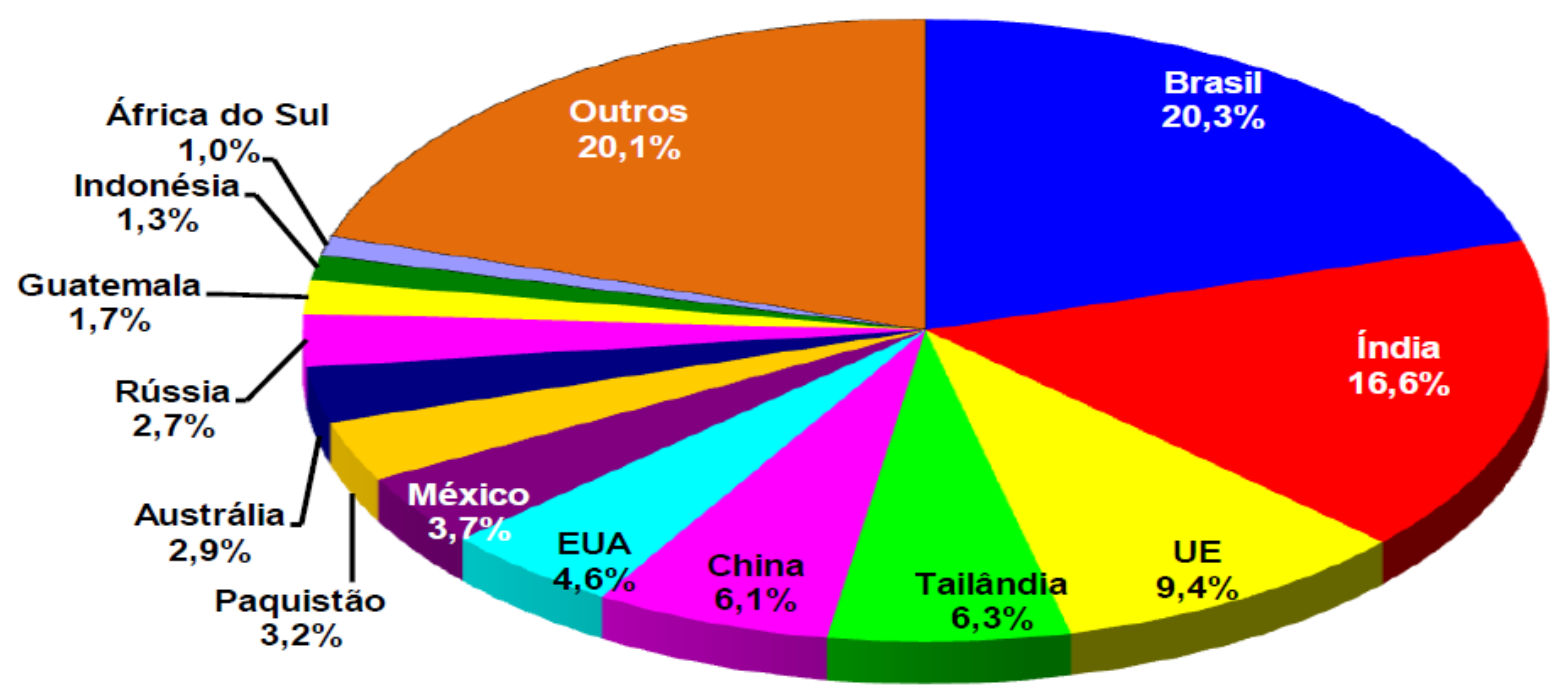

Fonte: USDA (2016) apud DEPEC-Bradesco (2016) 
Quando analisamos o mercado de açúcar, é importante ter presentes duas características fundamentais. A primeira delas é que se trata de uma commodity ${ }^{12}$ internacional, sujeita a pressões de mercado via intervenção estatal de alguns países como subsídios à produção e à exportação, distorcendo o livre-comércio.

Além disso, é preciso recordar que a matéria-prima para a produção do açúcar não é única para todo o mercado, sendo que alguns países como Brasil e Índia realizam sua produção a partir da cana, enquanto que na Europa se obtém açúcar a partir da beterraba, na América do Norte a partir do milho, na Tailândia a partir da mandioca e na China a partir do trigo.

Nesse sentido, a observação do mercado de açúcar precisa ser feita levando-se em conta que nem toda a produção referenciada é feita a partir de cana e, sobretudo, que não é - via de regra - realizada sob os ditames do livre-mercado, com a presença ostensiva de instrumentos protecionistas como tarifas, cotas e subsídios à produção e à exportação.

Por essa razão, é importante mirarmos também os dados de consumo e exportação para compreendermos o real destino final do açúcar produzido e a quem e de qual maneira o protecionismo impacta realmente os atores deste mercado. Para tanto, lançamos mãos dos dados dos gráficos 2 e 3 abaixo que, representam, respectivamente, o consumo e a exportação de açúcar por país.

Com base nos dados do gráfico 2, podemos perceber que, a despeito de Índia, União Europeia e China serem grandes produtores de açúcar, sua destinação é, em grande medida, o próprio mercado interno destes países, dado que lideram largamente o consumo do alimento - com 16,2\%, 10,9\% e 10,1\%, respectivamente, do total consumido - detendo quase metade do consumo mundial.

\footnotetext{
${ }^{12}$ Commodity é um termo utilizado no comércio internacional para descrever produtos de origem primária que não são diferenciados por marca ou origem e cujo intercâmbio obedece à oferta e à demanda, embora frequentemente possa sofrer com medidas protecionistas.
} 


\section{Gráfico 2 - Consumo Internacional de açúcar por país - Safra 2015/2016}

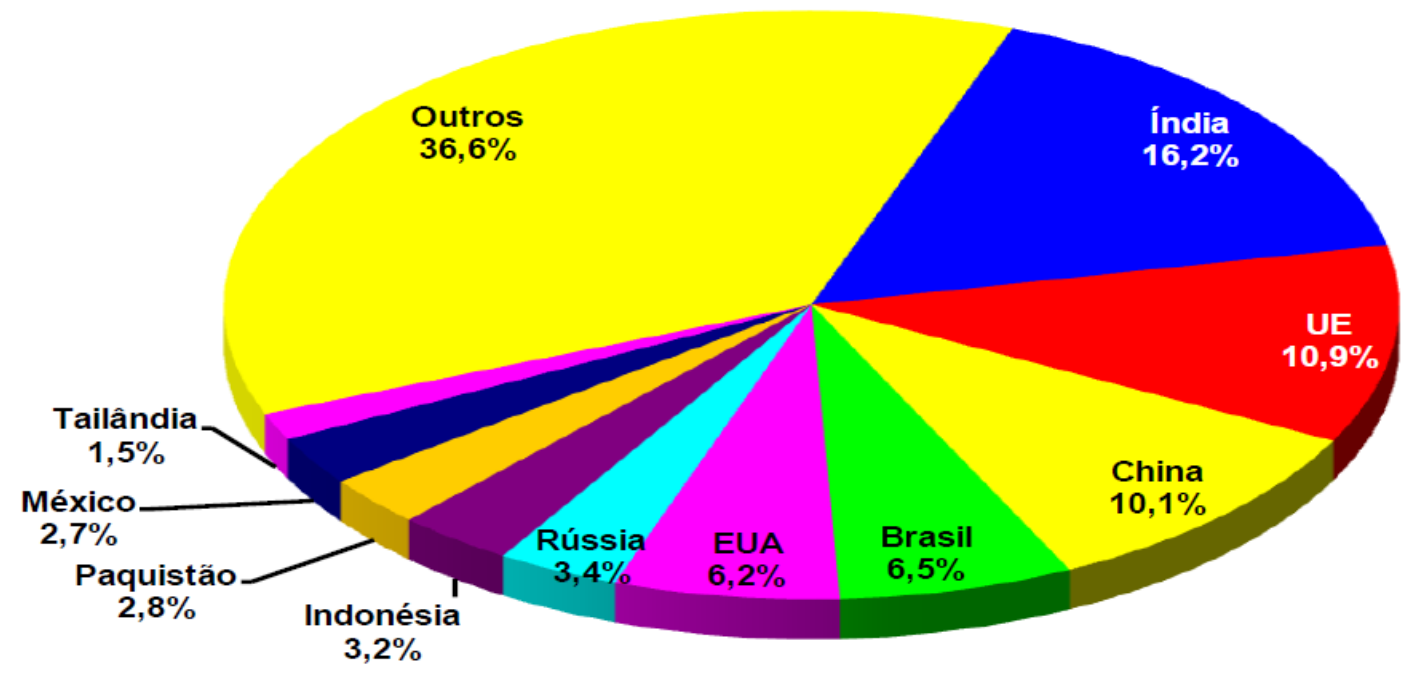

Fonte: USDA (2016) apud DEPEC-Bradesco (2016)

Desta forma, países que apresentam uma alta produção da commodity e relativo baixo consumo ${ }^{13}$, aparecerão como grandes exportadores no gráfico 3, como o Brasil, que lidera o ranking de exportadores com $43,4 \%$ do total de açúcar exportado no mundo e a Tailândia, que vem logo atrás com $16,1 \%{ }^{14}$, seguidos de Austrália (6,7\%), Índia (4,6\%), Guatemala (4,3\%), União Europeia (2,7\%), México (2,6\%), Cuba $(1,6 \%)$ e África do Sul (1,5\%).

\footnotetext{
${ }^{13}$ É importante ter presente que o baixo consumo é relativo na medida em que o Brasil apresenta uma alta taxa de consumo de açúcar per capita, mas sua população é inferior a da União Europeia e, sobretudo, às de Índia e China. Atualmente, de acordo com dados do USDA, o Brasil consome em seu mercado interno cerca de 11 milhões de toneladas/ano do produto.
}

${ }^{14}$ Se levarmos em conta o fato de que a produção do açúcar tailandês não é feita a partir da cana-deaçúcar, a liderança brasileira na exportação do produto é ainda mais pronunciada do que o gráfico 3 permite visualizar. 
Gráfico 3 - Exportação de açúcar por país - Safra 2015/2016

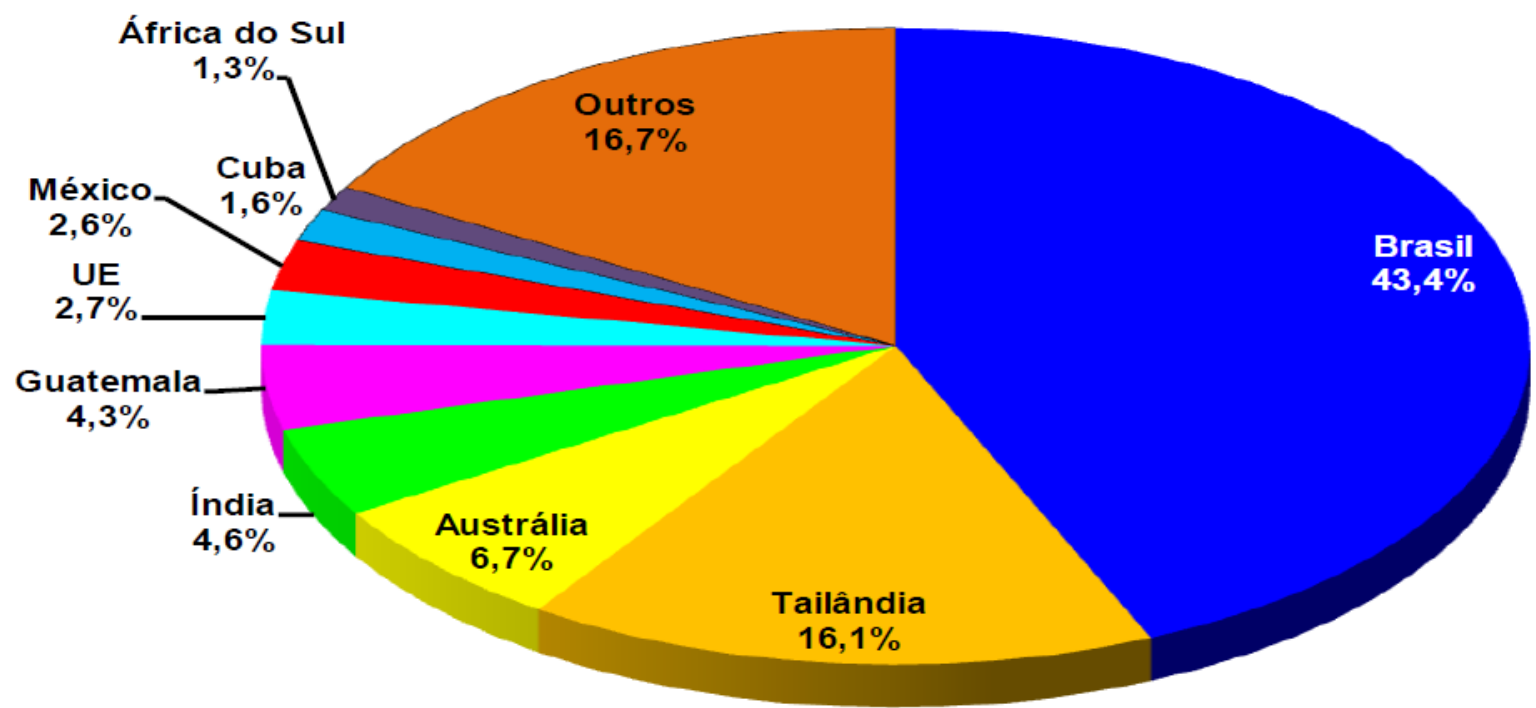

Fonte: USDA (2016) apud DEPEC-Bradesco (2016)

Detendo a liderança na produção e exportação de açúcar, o Brasil também aparece como um importante player no mercado de outro subproduto fundamental na cadeia de cana-de-açúcar: o etanol combustível, cujos dados apresentaremos em seguida.

\section{Etanol}

Atualmente, os principais insumos energéticos no mundo são derivados de combustíveis fósseis e seu consumo aumenta dia a dia, principalmente devido ao crescimento acelerado, ainda que num ritmo menor, de grandes economias emergentes como China e Índia. No entanto, os problemas associados a este tipo de combustíveis, que vão desde a emissão dos "gases de efeito estufa" - principais vilões do chamado "aquecimento global" - até questões geopolíticas de disponibilidade e/ou oferta imediata, levaram à crescente busca por fontes de energia alternativas.

Dessa maneira, os biocombustíveis constituem um tema cada vez mais frequente nos meios político e acadêmico, sendo objeto de estudos e protocolos tanto no âmbito interno quanto no internacional, sejam eles de qualquer natureza e/u geração, conforme a tecnologia utilizada. 
Esse crescente interesse pela energia renovável está ligado à politização de questões como as mudanças climáticas no Brasil e no mundo, pautando discussões e iniciativas ligadas à "economia verde" ou "economia de baixo carbono" e elevando a produção mundial desses biocombustíveis de pouco mais de 20 bilhões de litros em 2000 para mais de 100 bilhões de litros em 2012, conforme podemos observar no gráfico 4 abaixo.

\section{Gráfico 4 - Produção Global de Biocombustíveis (2000-2020)}

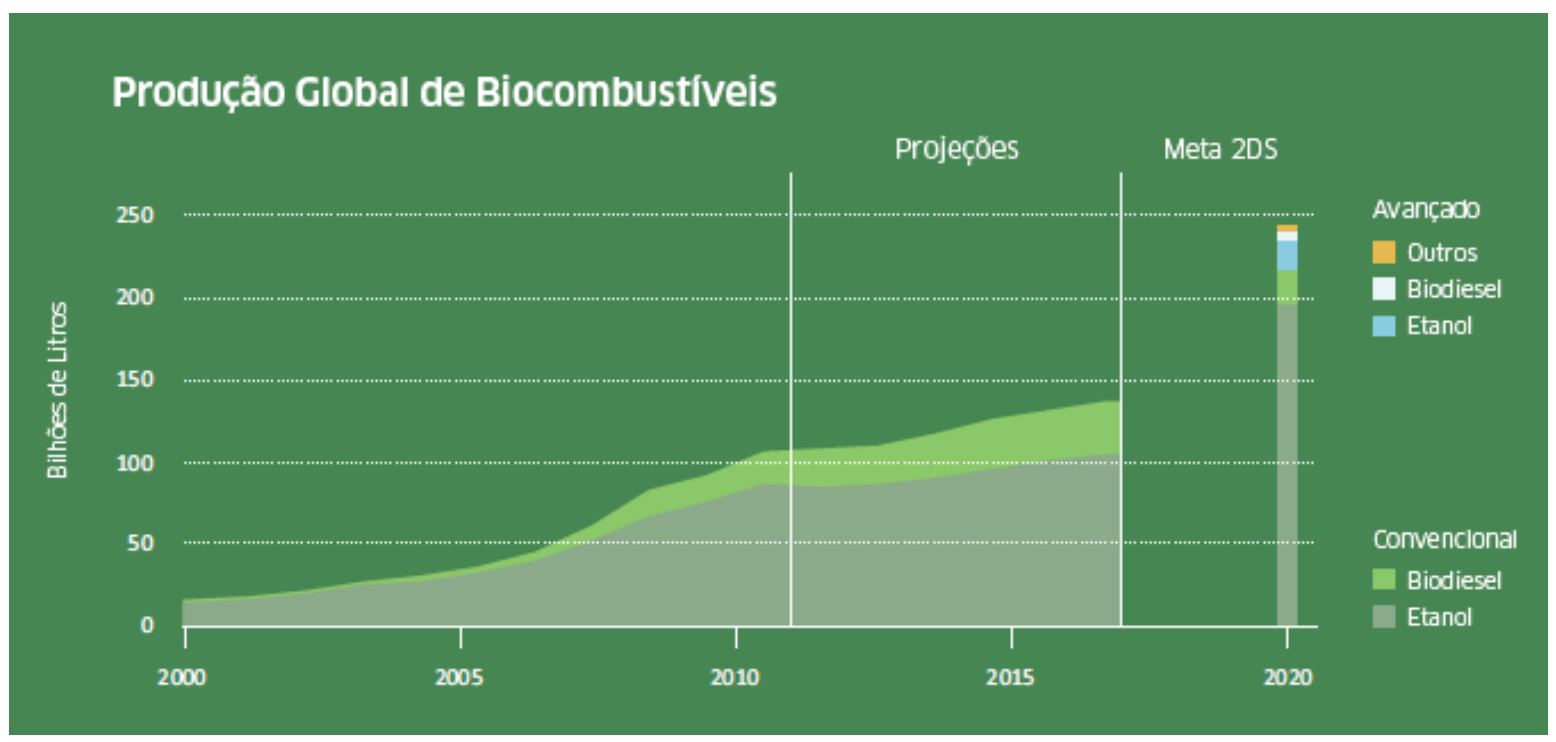

Fonte: AIE, 2013.

Apesar disso, é importante ressaltar que a matriz energética mundial ainda está eminentemente calcada nos combustíveis fósseis - principalmente no petróleo demonstrando, por meio do gráfico 5, que, apesar do crescimento da produção de biocombustíveis, o consumo das fontes tradicionais ainda é muito superior, legando um significativo desafio para seus defensores.

De acordo com os números levantados pelo chamado Dossiê Terra, em 2009, a proporção do consumo de combustíveis fósseis deverá chegar a ser dez vezes maior que a de fontes renováveis em 2030, ainda que o consumo destes últimos salte para quase o dobro do atualmente consumido. 
Gráfico 5 - Consumo Mundial de Energia por tipo de combustível (1990-2030)

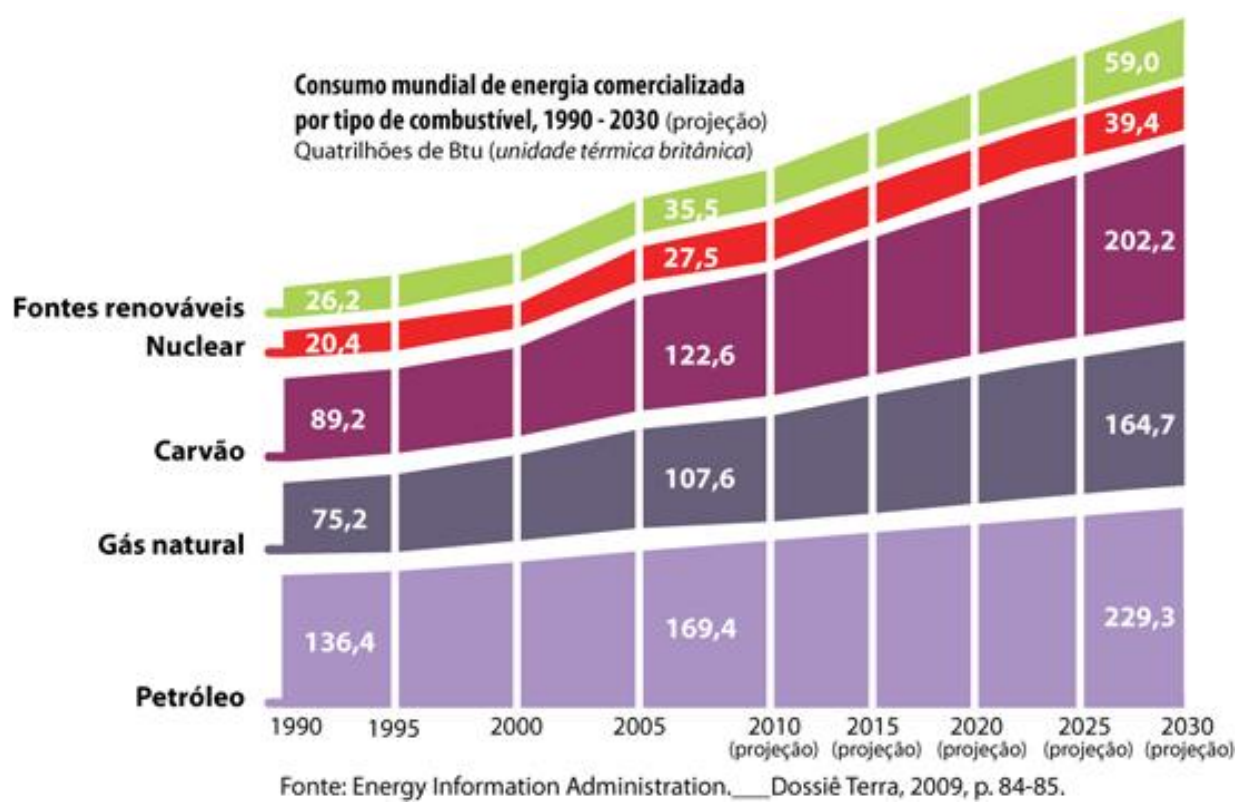

Fonte: Dossiê Terra, 2009.

Nesse sentido, é importante registrar que um dos grandes responsáveis pelo aumento da utilização de fontes renováveis foi o etanol, que, a exemplo do açúcar, pode ter origem em diversas culturas como a cana-de-açúcar, o milho, o trigo ou a beterraba. Na última safra consolidada de 2015/2016, de acordo com a USDA, o mundo produziu 98,3 bilhões de litros de etanol, sendo que a liderança coube aos Estados Unidos da América e ao Brasil com, respectivamente, 56 bilhões (57,5\%) e 30 bilhões $(27.7 \%)$ de litros produzidos, seguidos por União Europeia e China, conforme podemos observar no gráfico 6 abaixo.

O etanol norte-americano, contudo, possui como matriz produtiva o milho, cujo balanço energético ${ }^{15}$ - a exemplo da beterraba de que é feito o etanol europeu - é bastante inferior ao da cana-de-açúcar, sendo por isso considerado um biocombustível menos sustentável e de maior dificuldade para o cumprimento de determinadas metas ambientais impostas pelos próprios países.

\footnotetext{
${ }^{15}$ Balanço energético é a quantidade de energia renovável que se obtém a cada unidade de energia fóssil desprendida. Enquanto o balanço da cana-de-açúcar é de 8:1, o do milho é de 1,4:1 e o do trigo e da beterraba são de 1,8:1. (USDA, 2016).
} 
Gráfico 6 - Produção Internacional de etanol por país - Safra 2015/2016

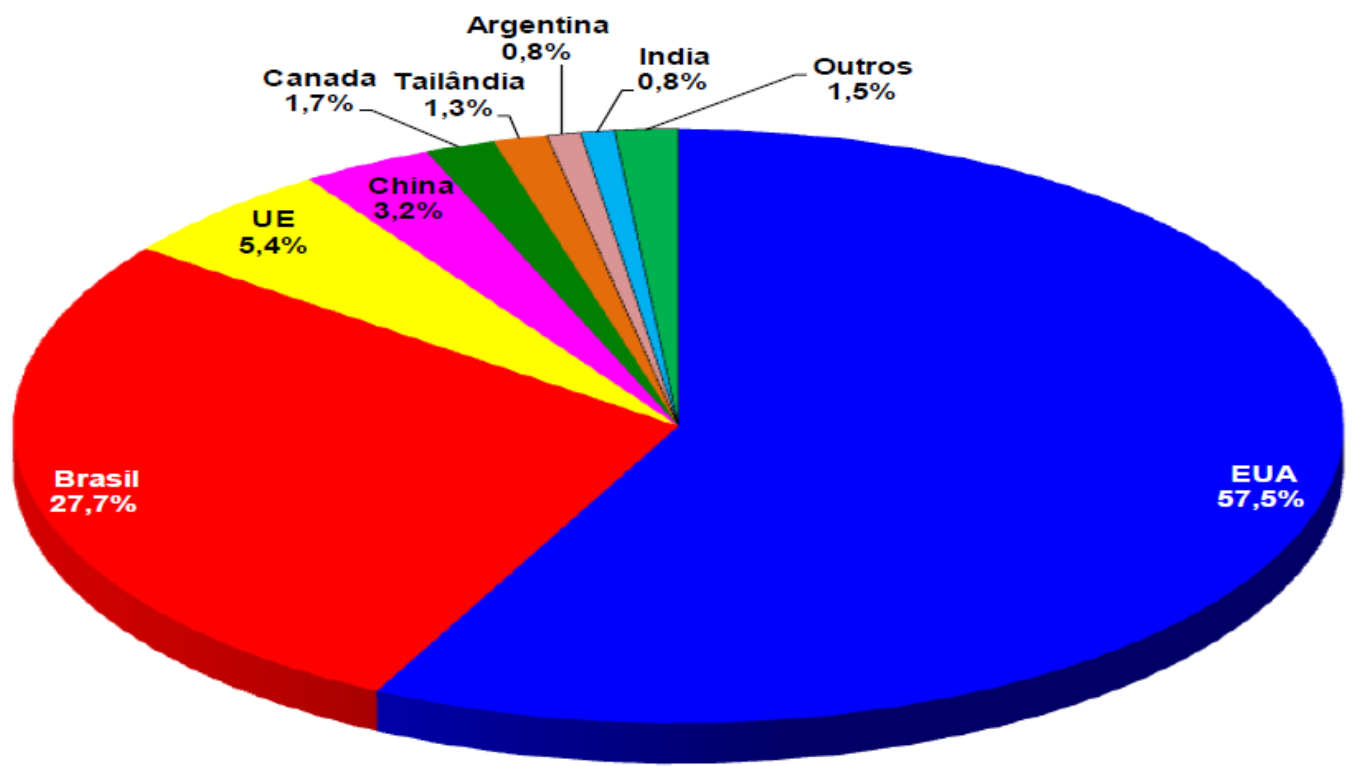

Fonte: USDA (2016) apud DEPEC-Bradesco (2016)

Cabe registrar ainda que cada país avançou de maneiras distintas - e cada qual com sua velocidade - na implantação de um programa de biocombustíveis em sua matriz energética. A figura 5 ilustra os diversos programas de biocombustíveis que utilizam o etanol ao redor do mundo. 
Figura 5. Mandatos de mistura e políticas públicas para o uso de etanol

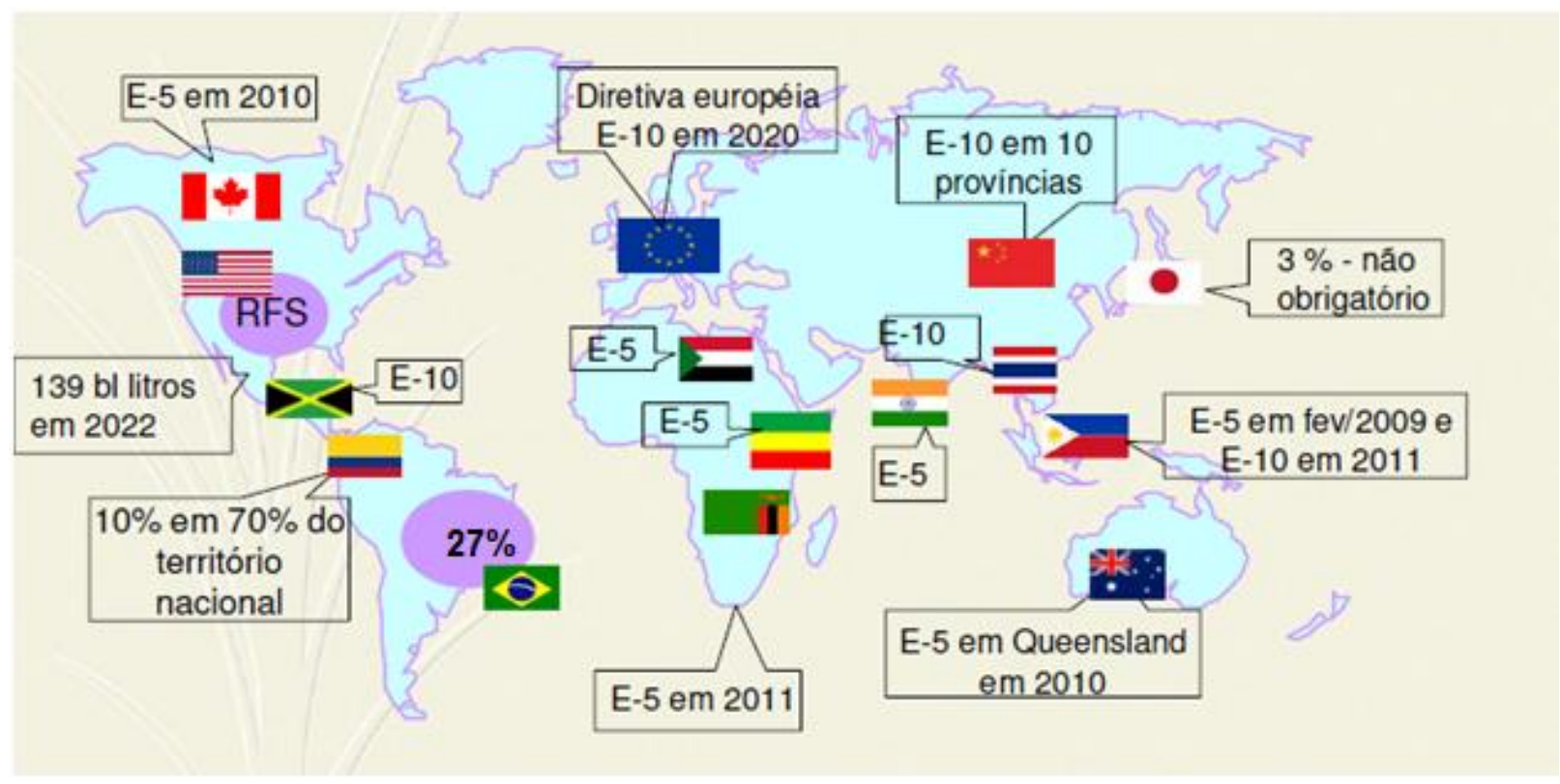

Fonte: JOLLY, Lindsay (2008) apud UNICA (2016)

Um dado importante a ressaltar é que o etanol é utilizado nestes países em sua versão anidro, ou seja, acrescido à gasolina como oxigenante. Assim, no termo En, $n$ indica a porcentagem de etanol adicionado à gasolina naquele país ou região, como por exemplo $10 \%$ na Jamaica ou 5\% na Índia.

O Brasil é o único a utilizar etanol hidratado $100 \%$ em seus automóveis, além dos $27 \%$ misturados à gasolina, sendo esta uma herança de um longo programa de adoção de álcool combustível (Proálcool) iniciado na década de 1970 e, mais recentemente, da implantação da tecnologia flex-fuel nos automóveis, permitindo que o motorista possa abastecer com etanol ou com gasolina, a depender das vantagens de cada combustível ${ }^{16}$.

O destaque em termos de abrangência e quantidade, para além do próprio Brasil, fica com os programas norte-americano e europeu, tanto por suas metas como pela população atingida. De acordo com Consentino (2011), no caso dos Estados Unidos da

\footnotetext{
${ }^{16}$ Em estudo anterior, na Dissertação de Mestrado referenciada em Consentino (2011), desenvolvemos um estudo pormenorizado acerca da evolução do uso de etanol combustível no Brasil bem como da institucionalização da representação de interesses do setor sucroalcooleiro brasileiro.
} 
América, o principal instrumento para a introdução de biocombustíveis na matriz energética norte-americana: o Renewable Fuel Standard (RFS) ${ }^{17}$, criado a partir da Lei de Política Energética. Tal dispositivo prevê a introdução de combustíveis renováveis à gasolina, desde que autorizado pela Agência de Proteção Ambiental Americana (EPA), sem, contudo, indexá-los ao consumo de combustíveis fósseis.

Mais recentemente, foi aprovada a Lei de Independência e Segurança Energética ${ }^{18}$ de 2007, a qual em, em realidade, constitui uma emenda bastante extensa da Lei de Política Energética de 2005 focada na diversificação de fontes - privilegiando as renováveis - em busca de uma maior autonomia do país com relação a seu consumo energético, inclusive prevendo uma busca por um etanol mais sustentável ${ }^{19}$.

Já no programa europeu, foi adotada, em 2009, uma nova Diretiva para Energia Renovável $^{20}$ que previa uma participação de $20 \%$ de energia renovável na matriz européia e $10 \%$ na matriz de transportes até 2020, além de metas de redução de gases e critérios de certificação sustentáveis ${ }^{21}$. Para se adequar a tais diretrizes, os então 27 Estados-membros devem adotar políticas nacionais de adoção de biocombustíveis e outros tipos de energia renovável ${ }^{22}$.

Apesar desta disseminação do uso do etanol combustível, é importante ter presente que a ascensão deste insumo não tem ocorrido de maneira pacífica e linear, uma vez que os diversos países que compõe este mercado lançam mão de barreiras tarifárias e não tarifárias com fins de favorecer os combustíveis fósseis ou sua própria

\footnotetext{
${ }^{17}$ Traduzindo ao português, seria algo como Padrão para Combustíveis Renováveis. Optamos por não traduzir o RFS por se tratar de um instituto reconhecido internacionalmente por sua sigla, sendo utilizado dessa forma inclusive em trabalhos acadêmicos e publicações do setor.
}

${ }^{18}$ No original, Energy and Independence Security Act (EISA), também conhecido como Energy Bill.

${ }^{19}$ Dos 136 bilhões de litros de etanol a serem produzidos até 2022, apenas 57 milhões poderão ser derivados do milho.

${ }^{20}$ Renewable Energy Directive (RED) é a alcunha pela qual é conhecida a Diretriz 2009/28/EC.

${ }^{21}$ As metas e os critérios estão dispostos no artigo 17 da Diretiva. Enquanto as metas de redução são de $35 \%$ até 2013, 50\% até 2015 e 60\% até 2018, os critérios estão ligados a impedimentos de produção dos biocombustíveis em biomas biodiversos, com alto teor de carbono e pantanais. (Comissão da UE, 2011).

${ }^{22}$ A escolha entre os diferentes tipos de combustíveis renováveis fica a critério de cada país. 
indústria renovável. Com tais medidas, acabam por retardar a disseminação do etanol a um custo baixo e preços competitivos, distorcendo seu livre comércio e sua propagação como alternativa energética segura. (Pacini e Assunção, 2011).

Estas barreiras vão desde tarifas e sobretaxas ao produto importado como subsídios aos produtores internos, apesar de tal realidade estar mudando. Nos Estados Unidos da América, por exemplo, os subsídios à produção e as tarifas de exportação estão sendo derrubadas. Já na União Europeia, as tarifas aplicadas são da ordem de 0,192 euros/litro para o etanol desnaturado. Além disso, vale lembrar o subsídio inscrito na Política Agrícola Comum do bloco, em seu Programa de Remuneração de Culturas Energéticas - que prevê transferências de quarenta e cinco euros por hectare cultivado com lavouras destinadas à produção de energia.

Alguns obstáculos aos biocombustíveis, no entanto, não constituem necessariamente medidas deliberadamente restritivas contra o insumo ou práticas desleais de comércio, mas antes modalidades de regulação de sua produção, intercâmbio e utilização por meio da adoção de padrões socioambientais confiáveis que, de alguma forma, buscam minimizar alguns impactos socioambientais oriundos do modus operandi da agroindústria canavieira. (Pacini e Assunção, idem).

Tais impactos são diversos e multifacetados, sendo bastante difícil esgotar uma lista única para todo o setor sucroalcooleiro. Por meio dos trabalhos de Luciana Rodrigues (2010) e Leonardo Silva (2010), contudo, buscamos resumir os principais impactos ambientais e sócio-econômicos envolvidos no setor, conforme o quadro 7 abaixo:

Quadro 7 - Impactos ambientais e sócio-econômicos causados pela cadeia de canade-açúcar

\begin{tabular}{|l|l|l|}
\hline Impactos ambientais & Impactos sócio-econômicos \\
\hline - Redução da biodiversidade, causada & - Práticas trabalhistas pouco ordenadas \\
pelo desmatamento e pela & juridicamente \\
implantação da monocultura & - Reconfiguração do modo de vida e \\
- Expansão da fronteira agrícola para & atividades rurais \\
áreas de proteção ambiental & - Concentração da propriedade fundiária \\
- Contaminação do solo e das águas & - Exodo rural de pequenos \\
superficiais e subterrâneas por & proprietários e pressão sobre a \\
\hline
\end{tabular}




\begin{tabular}{|c|c|}
\hline $\begin{array}{l}\text { efluentes, devido à forma como se } \\
\text { aduba e fertiliza o solo } \\
\text { - Comprometimento da qualidade e } \\
\text { disponibilidade de água para } \\
\text { abastecimento } \\
\text { - Compactação e desgaste do solo, } \\
\text { devido ao tráfego de maquinário } \\
\text { pesado } \\
\text { - Assoreamento dos corpos d'água } \\
\text { - Desmate de áreas ciliares } \\
\text { Alteração da qualidade do ar e do } \\
\text { clima na região de plantio devido às } \\
\text { queimadas } \\
\text { Emissão de fuligem e gases do efeito } \\
\text { estufa pela queima da palha } \\
\text { Danos à flora e à fauna próximas } \\
\text { devido ao desmate e às queimadas } \\
\text { Aumento da poluição devido ao } \\
\text { consumo intenso de óleo diesel nas } \\
\text { etapas do plantio, colheita e } \\
\text { transporte }\end{array}$ & $\begin{array}{l}\text { infra-estrutura urbana } \\
\text { - Comprometimento da oferta de } \\
\text { alimentos em algumas localidades } \\
\text { - Crescimento do desemprego e } \\
\text { subemprego diante da mecanização } \\
\text { de algumas etapas e da entressafra } \\
\text { - Aumento dos problemas de saúde } \\
\text { dos trabalhadores relacionados à } \\
\text { pressão pela produtividade } \\
\text { - Aumento da deterioração das } \\
\text { rodovias sobrecarregadas pelo } \\
\text { transporte dos insumos nas regiões } \\
\text { produtivas. } \\
\text { Suspeitas de trabalho infantil na } \\
\text { lavoura }\end{array}$ \\
\hline
\end{tabular}

Fonte: elaborado pelo autor a partir de Rodrigues (2010) e Silva (2010).

Como podemos observar, a natureza destes impactos, tanto na esfera ambiental como na esfera sócio-econômica, tem sido bastante ampla e diversa, desde os mais diretos relacionados ao cultivo e colheita da cana como os que se relacionam indiretamente como aqueles que estão ligados ao transporte ou à condição dos trabalhadores envolvidos na cadeia da cana. Por este ponto de vista, a regulação é fundamental para este setor, encerrando questões bastante importantes sobre sua governança e a interação entre os sistemas privados e as normativas estatais presentes em tal tarefa. 
Aliada a essa questão, a disseminação desse mercado internacional de biocombustíveis suscitou a questão da motivação dos consumidores ${ }^{23}$ que, alterando suas preferências usuais, passaram a utilizar mais os biocombustíveis em lugar dos combustíveis fósseis. Nesse sentido, além do preço final, outras variáveis começaram a ser levadas em conta, tais como os padrões de produção e manejo desses insumos e seu impacto no meio ambiente.

\subsection{Certificações socioambientais na cadeia de açúcar e etanol}

$\mathrm{Na}$ esteira desse processo, emergem as iniciativas de certificação para os biocombustíveis, que têm se adensado de maneira bastante significativa, desde o início do século XXI. O panorama atual destes arranjos é caracterizado por uma série de iniciativas de certificação, cada qual com critérios próprios de sustentabilidade para estes combustíveis, sendo as principais listadas na tabela 2, abaixo:

Tabela 2 - Principais iniciativas de certificação para biocombustíveis, sua natureza e os responsáveis

\begin{tabular}{clc}
\hline Certificações & Natureza & Responsáveis \\
\hline NEN - Netherlands Standardization & Nacional & Holanda \\
Institute & & \\
NTA 8080 & Nacional & Holanda \\
eTHA STAR & Nacional & Suíça \\
RFTO - Renewable Transport Fuel & Nacional & Reino Unido \\
Obligation & & \\
BNS - Biomass Nippon Strategy & Nacional & Japão \\
VSE - Verified Sustainable Ethanol & Nacional & Suécia \\
RFS - Renewable Fuel Standard & Nacional & EUA \\
\hline
\end{tabular}

\footnotetext{
${ }^{23}$ Aqui não estamos debatendo apenas as preferências de cada indivíduo, mas também as preferências agregadas de estados nacionais, empresas multinacionais, ONGs e outros atores coletivos que, de alguma forma, constituem-se como direcionadores do consumo dos indivíduos.
} 


\begin{tabular}{|c|c|c|}
\hline LCFS - Low Carbon Fuel Standard & Nacional & EUA \\
\hline Zoneamento de Cana & Nacional & Brasil \\
\hline Protocolo Verde & Nacional & Brasil \\
\hline Diretiva Europeia & Regional & União Europeia \\
\hline Greenenergy & Regional - Nacional & $\begin{array}{l}\text { União } \\
\text { Europeia/Holanda }\end{array}$ \\
\hline 2BSvs & Regional - Nacional & $\begin{array}{l}\text { União } \\
\text { Europeia/França }\end{array}$ \\
\hline $\begin{array}{c}\text { ISCC - International Sustainability } \\
\text { \& Carbon Certification }\end{array}$ & Regional - Nacional & $\begin{array}{l}\text { União } \\
\text { Europeia/Alemanha }\end{array}$ \\
\hline $\begin{array}{l}\text { RBSA - RED Bioenergy } \\
\text { Sustainability Assurance }\end{array}$ & Regional - Nacional & $\begin{array}{l}\text { União } \\
\text { Europeia/Espanha }\end{array}$ \\
\hline $\begin{array}{l}\text { BEFSCI - Bioenergy and Food } \\
\text { security Criteria and Indicators }\end{array}$ & $\begin{array}{l}\text { Internacional - } \\
\text { Nacional }\end{array}$ & $\begin{array}{c}\text { Alemanha/FAO - } \\
\text { ONU }\end{array}$ \\
\hline $\begin{array}{c}\text { GBEP - Global Bioenergy } \\
\text { Partnership }\end{array}$ & Internacional & $\begin{array}{l}\text { FAO - ONU, G8 } \\
\text { ampliado e AIE }\end{array}$ \\
\hline Task 39 & Internacional & OCDE e AIE \\
\hline Substa CBD & Internacional & $\mathrm{CBD}$ \\
\hline Equator Principles & Internacional & IFC \\
\hline Scorecard & Internacional & BID \\
\hline IFC Principles & Internacional & IFC \\
\hline PC -248 & Internacional & ISSO \\
\hline National Commitment & $\begin{array}{l}\text { Multistakeholder - } \\
\text { nacional }\end{array}$ & Brasil \\
\hline $\begin{array}{c}\text { CSBP - Council on } \\
\text { Sustainable Biomass Production }\end{array}$ & $\begin{array}{l}\text { Multistakeholder - } \\
\text { nacional }\end{array}$ & EUA \\
\hline $\begin{array}{c}\text { RTRS - Roundtable on Sustainable } \\
\text { Soy (RSB - Soja) }\end{array}$ & $\begin{array}{l}\text { Multistakeholder - } \\
\text { internacional }\end{array}$ & Diversos membros \\
\hline $\begin{array}{c}\text { RSPO - Roundtable on Sustainable } \\
\text { Palm Oil (RSB - Palma) }\end{array}$ & $\begin{array}{l}\text { Multistakeholder - } \\
\text { internacional }\end{array}$ & Diversos membros \\
\hline $\begin{array}{c}\text { BSI -BONSUCRO (RSB - Etanol de } \\
\text { Cana) }\end{array}$ & $\begin{array}{l}\text { Multistakeholder - } \\
\text { internacional }\end{array}$ & Diversos membros \\
\hline Rainforest (Florestas) & Multistakeholder - & Diversos membros \\
\hline
\end{tabular}


internacional

Fonte: elaborada pelo autor com dados de Desplechin (2014)

Diante da observação da tabela, podemos constatar que as iniciativas se dividem em quatro tipos principais - nacionais, regionais, internacionais, multistakeholder - que são encontrados de maneira pura (somente uma natureza) ou combinadas (mais de uma natureza). As iniciativas nacionais são aquelas levadas a cabo no âmbito de um estado, normalmente pelos próprios governos nacionais como o holandês (NEN, NTA 8080), o japonês (BNS), o suíço (eTHA STAR), o sueco (VSE), o norte-americano (RFS e LCFS), o inglês (RFTO) e o brasileiro (Zoneamento da Cana e Protocolo Verde).

Já no âmbito regional, a Diretiva Europeia de 2009 sobre biocombustíveis acaba por balizar uma série de arranjos em que a União Europeia associa-se aos governos nacionais (ou atores não-estatais) de alguns países para promover a certificação no âmbito dos biocombustíveis. Nessa estratégia, destacam-se as seguintes iniciativas: Greenenergy (UE-Holanda), 2BSvs (UE-França), ISCC (UE-Alemanha) e RBSA (UEEspanha).

Outra possibilidade são as chamadas certificações internacionais, levadas a cabo por organizações internacionais - de caráter intergovernamental ou privado - e, por vezes, associadas entre si ou com estados nacionais. Os exemplos mais importantes deste tipo de iniciativa são a GBEP (parceria entre a Organização das Nações Unidas para Alimentação e Agricultura, o G8 e a Agência Internacional de Energia), a Task 39 (cooperação entre a Organização para Cooperação e Desenvolvimento Econômico e a Agência Internacional de Energia), a Substa CBD (organizada pela Convenção sobre Diversidade Biológica), os Princípios do Equador e os Princípios da Corporação Financeira Mundial (organizada pela corporação homônima, ligada ao Banco Mundial), a Scorecard (organizada pelo Banco Interamericano de Desenvolvimento- BID), a PC 248 (organizada pela Organização Internacional de Padronização- ISO) e a BEFSCI (parceria entre a Organização das Nações Unidas para Alimentação e Agricultura e o governo alemão).

Por fim, existem as iniciativas denominadas multistakeholder, ou seja, aquelas levadas a cabo por diversas partes interessadas, em níveis diferentes de atuação, sendo eles essencialmente atores e organizações não-estatais. Nesta modalidade, encontramos 
dois tipos diferenciados: as multistakeholder nacionais - como o National Commitment do Brasil e a CSBP norte-americana - e as multistakeholder internacionais - como as chamadas roundtables organizadas em torno da soja (RTRS), do olho de palma (RSPO), das florestas (Rainforest) e, finalmente, do etanol de cana (BSI-Bonsucro).

Diante dessa profusão de iniciativas, alcunhada por Marcos Nappo como " $a$ babel das certificações" ${ }^{24}$, grande parte delas acaba se tornando repetitiva e, até mesmo, ineficiente para o que se propõe, ou seja, regular de maneira abrangente o setor de biocombustíveis. (Kaphengst et alli, 2009).

Outra forma de diferenciar estas iniciativas é recorrendo à tipologia de Van Dam e Juginger (2008), a qual propõem que os arranjos de certificação listados acima sejam dispostos de acordo com o escopo (nacionais-globais) e a obrigatoriedade (voluntáriosmandatórios). Nesse modelo, exposto na Figura 6, a primeira abordagem seria a pura e simples regulação nacional que, apesar do uso de critérios mínimos como a emissão dos GEEs, garantiria maior confiabilidade na certificação.

\section{Figura 6. Mecanismos propostos para governança da bioenergia}

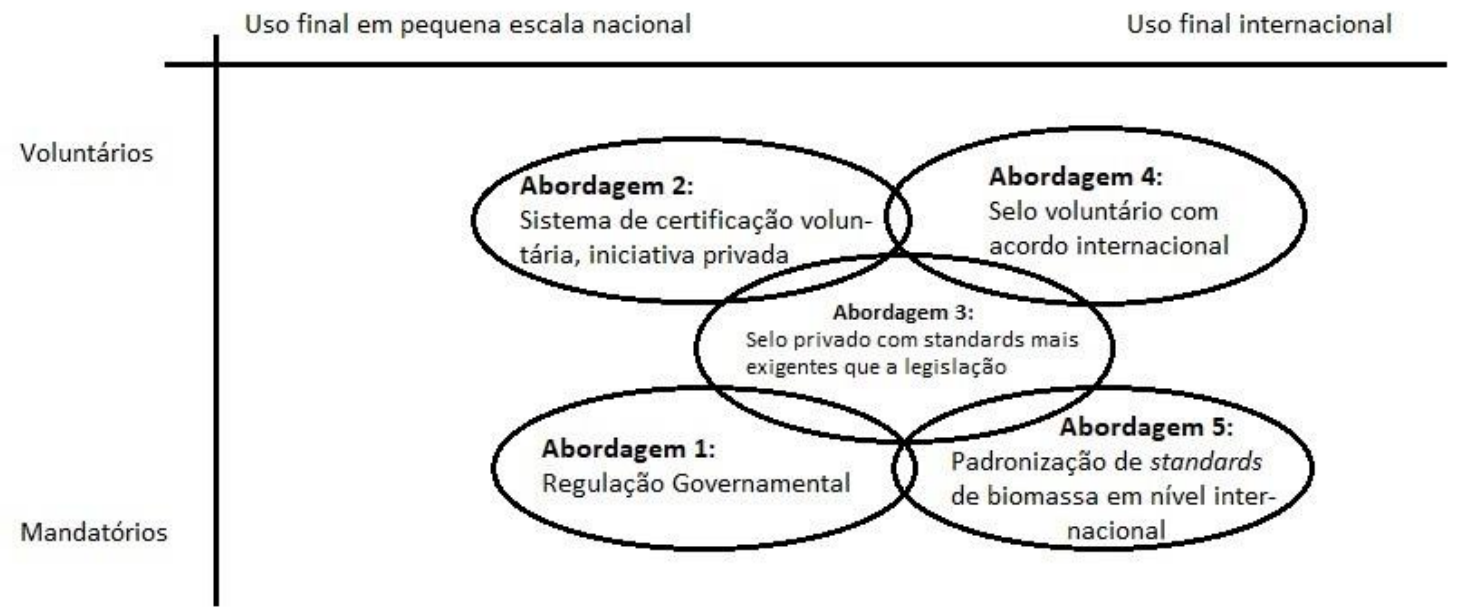

Fonte: Van Dam e Juginger (2008), adaptado e traduzido pelo autor.

\footnotetext{
${ }^{24}$ Nappo utiliza esta expressão para abordar o problema em seu artigo "Certificação socioambiental: benefício ou obstáculo?" (UNICA, 2008).
} 
Em seguida, a segunda abordagem - a certificação voluntária de padrões mínimos - traz as vantagens da flexibilidade e as desvantagens de ser um processo que não envolve muitos atores, ressaltando-se a baixa confiabilidade imputada a elas devido aos critérios pré-moldados para o cumprimento das próprias empresas que os engendraram. Para a terceira abordagem, temos a certificação voluntária calcada em padrões mais elevados que a legislação vigente onde se busca uma solução de compromisso entre os dois mecanismos anteriores, em que se adota um piso obrigatório de critérios e faculta àqueles que queiram ir além da letra da lei, o acesso a novos mercados.

Para a quarta abordagem, a certificação voluntária combinada com acordo internacional, resultaria em uma maior confiabilidade, a qual viria por meio das organizações internacionais que endossassem o tratado, fazendo com que a regulação pudesse ser de grande valia para o comércio internacional. Por fim, a quinta abordagem, apresentada como a padronização de requisitos mínimos em nível internacional, contempla um padrão mínimo de critérios - a exemplo das regulações nacionais - mas diferencia-se destas ao estender sua obrigatoriedade para o plano externo.

Nesse sentido, esta quinta abordagem seria a mais abrangente e dotada de um conjunto de critérios para a ação coletiva, sendo identificada, entre os esquemas listados, com o caso do BSI-Bonsucro, o qual pretendemos estudar, no capítulo seguinte. 


\section{CAPÍTULO 3: ESTUDO DE CASO - BSI BONSUCRO}

Após examinarmos nos dois primeiros capítulos os aspectos mais gerais da certificação e a cadeia da cana-de-açúcar, cabe agora analisarmos o caso da iniciativa mais abrangente em termos de participantes neste setor - a BSI-Bonsucro compreendendo também sua estrutura institucional e sua governança interna.

Esta iniciativa consiste naquilo que chamamos de caso típico (Gerring, 2007), ou seja, aquele que consideramos o mais abrangente e efetivo arranjo de certificação exclusivamente privada para o setor sucroalcooleiro, a qual ganhou grande projeção devido ao apoio dos produtores brasileiros que, como vimos, respondem pelas maiores fatias de mercado de açúcar e de etanol de cana do planeta

\subsection{Histórico e características}

Para começar a compreender como surge a ideia de certificação de cana de açúcar, é preciso voltar os olhos para setembro de 2007, quando as chancelarias do Brasil e da Suécia assinaram um protocolo de cooperação técnica para buscar soluções de sustentabilidade no setor sucroalcooleiro.

Por meio deste instrumento, foi possível a constituição da SEKAB Verified Sustainable Ethanol Initiative que congregava produtores brasileiros e a empresa energética sueca de mesmo nome em um esforço para atingir determinados critérios para a produção e manejo de cana tais como: i) redução de $85 \%$ de emissões de dióxido de carbono em comparação com o petróleo; ii) aumentar a utilização de colheita mecanizada; iii) fim do desmatamento florestal e exploração do trabalho infantil; iv) respeito aos direitos e à segurança trabalhistas dos empregados na cadeia da cana, de acordo com os ditames das Nações Unidas, entre outros (Zezza, 2013).

Estas iniciativas de certificação começaram a se estabelecer por meio de um processo que combinou a demanda de grandes atores industriais cuja cana é a matériaprima fundamental - como Coca-Cola e Nestlé - com a pressão de grupos sociais e organizações não-governamentais, como a $\mathrm{WWF}^{25}$, por uma produção e um manejo mais sustentáveis da cana.

\footnotetext{
${ }^{25}$ WWF - World Wildlife Fund - organização não governamental internacional, surgida na Suíça em 1961, presente em mais de 90 países.
} 
Diante de um provável surgimento e disseminação de esquemas rivais, os produtores canavieiros do Brasil buscaram concentrar esforços na busca de uma alternativa mais abrangente e de maior prestígio internacional, associando-se paulatinamente ao que viria a ser a BSI-Bonsucro.

A BSI - Bonsucro é uma instituição multistakeholder (MSI) de caráter internacional, surgida em 2005, que tem como objetivo a certificação de insumos obtidos da cana-de-açúcar, inclusive o biocombustível obtido a partir desta cultura: o etanol. Inicialmente chamada apenas de Better Sugar Initiative e gestada no interior da $\mathrm{WWF}^{26}$, alcançou um status jurídico próprio em 2009, registrando-se sob as leis britânicas e galesas como uma organização sem fins lucrativos, buscando promover práticas sustentáveis de produção e manejo.

A partir do final de 2010 e início de 2011, a agora chamada BSI - Bonsucro enveredou para o desenvolvimento de um mecanismo de certificação para assegurar o cumprimento dessas práticas, frente a constantes denúncias de padrões sociais e ambientais baixos no setor sucroalcooleiro. Os princípios que norteiam os critérios a serem observados para se obter a certificação são: i) a observação estrita da legislação nacional vigente; ii) respeito aos direitos humanos e padrões trabalhistas; iii) gerenciamento da produção e manejo eficientes em relação à sustentabilidade ; iv) gerenciamento ativo da biodiversidade no ecossistema inserido e v) compromisso contínuo com a inovação em áreas centrais dos referidos negócios. (Guariguata et alli, 2011). Além disso, adotou-se um novo e sexto rol de princípios a fim de adequar a certificação BSI-Bonsucro à Diretiva de Energia Renovável da União Europeia de 2009.

Diante de tais princípios, é de suma importância analisar cada um deles e compreender os critérios a eles associados, eventualmente segmentando alguns em indicadores, conforme as definições da própria iniciativa, como indicarão os fluxogramas abaixo.

O primeiro princípio - observação estrita da legalidade - traz em seu bojo dois importantes critérios: i) conformidade com as leis, regulações e licenciamentos aplicáveis $^{27}$ e ii) comprovação do título de posse da terra e a legalização do acesso a água, de acordo com a legislação vigente, com seus respectivos indicadores ${ }^{3}$ (Figura 7).

\footnotetext{
${ }^{27}$ De acordo com este critério, sempre que as normas do BSI-Bonsucro forem mais rigorosas que a legislação deverá prevalecer o que dizem as normas da iniciativa, sendo as seguintes áreas contempladas:
} 


\section{Figura 7 - Fluxograma de Critérios do BSI-Bonsucro para o Princípio I -}

\section{Observação estrita da legalidade}

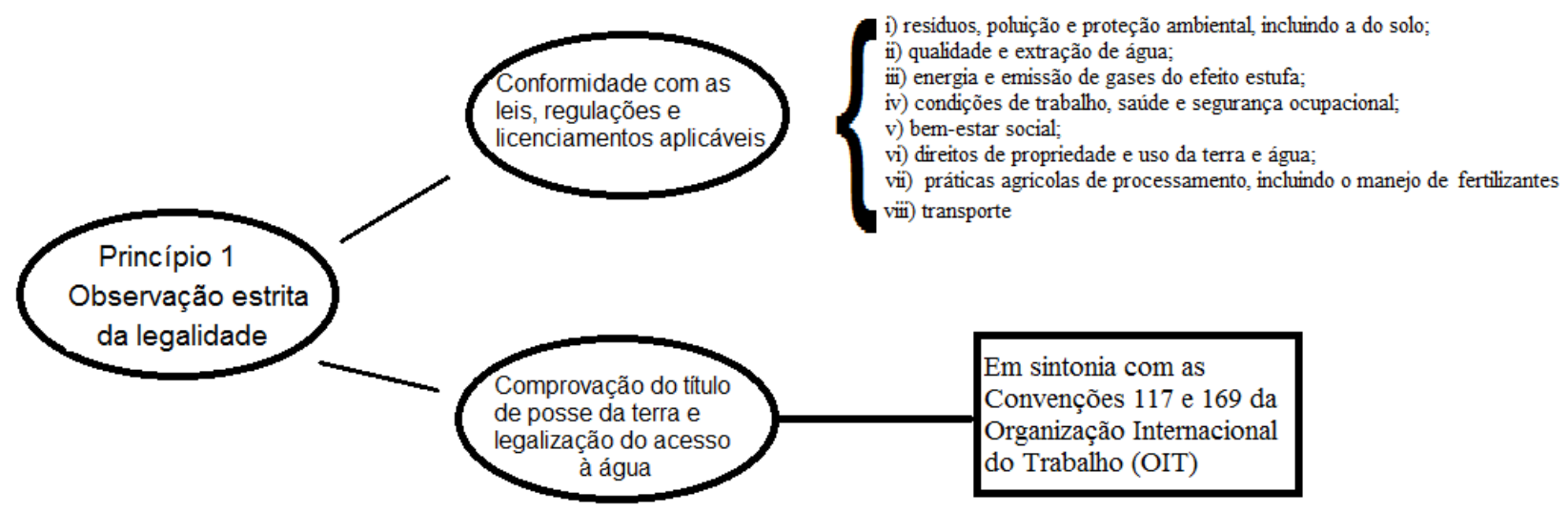

Fonte: Elaborado pelo ator com base no Guia para o Padrão de Produção Bonsucro 2015

O segundo princípio enunciado (Figura 8), qual seja o do respeito aos direitos humanos e padrões trabalhistas, traz um rol de critérios mais complexo e multifacetado: i) cumprimento das convenções trabalhistas da OIT (Organização Internacional do Trabalho); ii) proporcionar um ambiente seguro e saudável aos trabalhadores da cadeia de cana; iii) pagar aos funcionários um piso salarial condizente com, pelo menos, o salário mínimo nacional e iv) fornecer contratos claros, equitativos e abrangentes.

Para o cumprimento do primeiro critério, os indicadores escolhidos determinam o estabelecimento de uma idade mínima para os trabalhadores do setor bem como a ausência de trabalho forçado e discriminação. Ademais, mira-se o respeito à

i) resíduos, poluição e proteção ambiental, incluindo a do solo; ii) qualidade e extração de água; iii) energia e emissão de gases do efeito estufa; iv) condições de trabalho, saúde e segurança ocupacional; v) bem-estar social; vi) direitos de propriedade e uso da terra e água; vii) práticas agrícolas de processamento, incluindo o manejo de fertilizantes e viii) transporte

\footnotetext{
${ }^{3}$ Esta legislação é regulada, principalmente, pelas Convenções 117 e 169 da Organização Internacional do Trabalho.
} 
sindicalização dos profissionais e a possibilidade de estes aderirem às negociações coletivas no âmbito de sua categoria.

Figura 8 - Fluxograma de Critérios do BSI-Bonsucro para o Princípio II Respeito aos Direitos Humanos e aos padrões trabalhistas

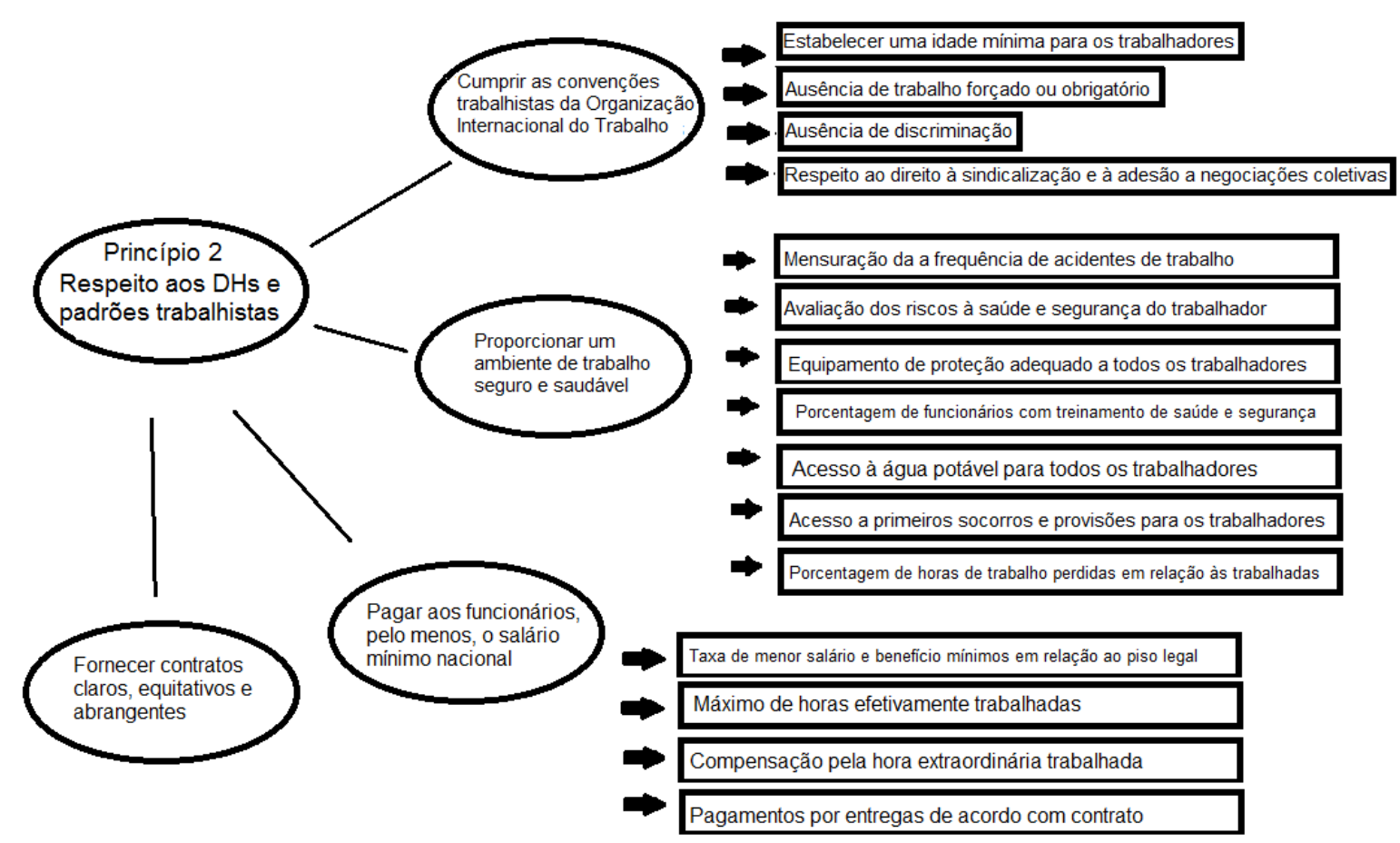

Fonte: Elaborado pelo ator com base no Guia para o Padrão de Produção Bonsucro 2015

O segundo critério encerra mais indicadores, voltados à segurança e a saúde dos trabalhadores: i) mensuração da frequiência dos acidentes de trabalho; ii) avaliação dos riscos à saúde e segurança do trabalhador; iii) presença de equipamentos de proteção adequados a todos os trabalhadores - funcionários ou não das usinas; iv) percentagem de funcionários com treinamento em saúde e segurança no trabalho; v) acesso à água potável para os trabalhadores; vi) acesso a primeiros socorros e provisões emergenciais para os trabalhadores e vii) percentagem de horas de trabalho perdidas por horas trabalhadas, decorrentes de desinteresse e/ou problemas associados à saúde.

No âmbito do terceiro critério, buscam-se os indicadores do menor piso salarial e de benefícios, do máximo de horas trabalhadas, da compensação pela hora extra e os 
pagamentos por entrega de cana feitos de acordo com o que foi previsto contratualmente.

Já o terceiro princípio (Figura 9) abarca dois critérios: i) o monitoramento da eficiência e mensuração do impacto da produção no setor sucroalcooleiro visando constantes melhorias e ii) a monitoração de emissão de gases para minimizar o impacto das mudanças climáticas.

Figura 9 - Fluxograma de Critérios do BSI-Bonsucro para o Princípio III Administrar os insumos, a produção e a eficiência em prol da sustentabilidade

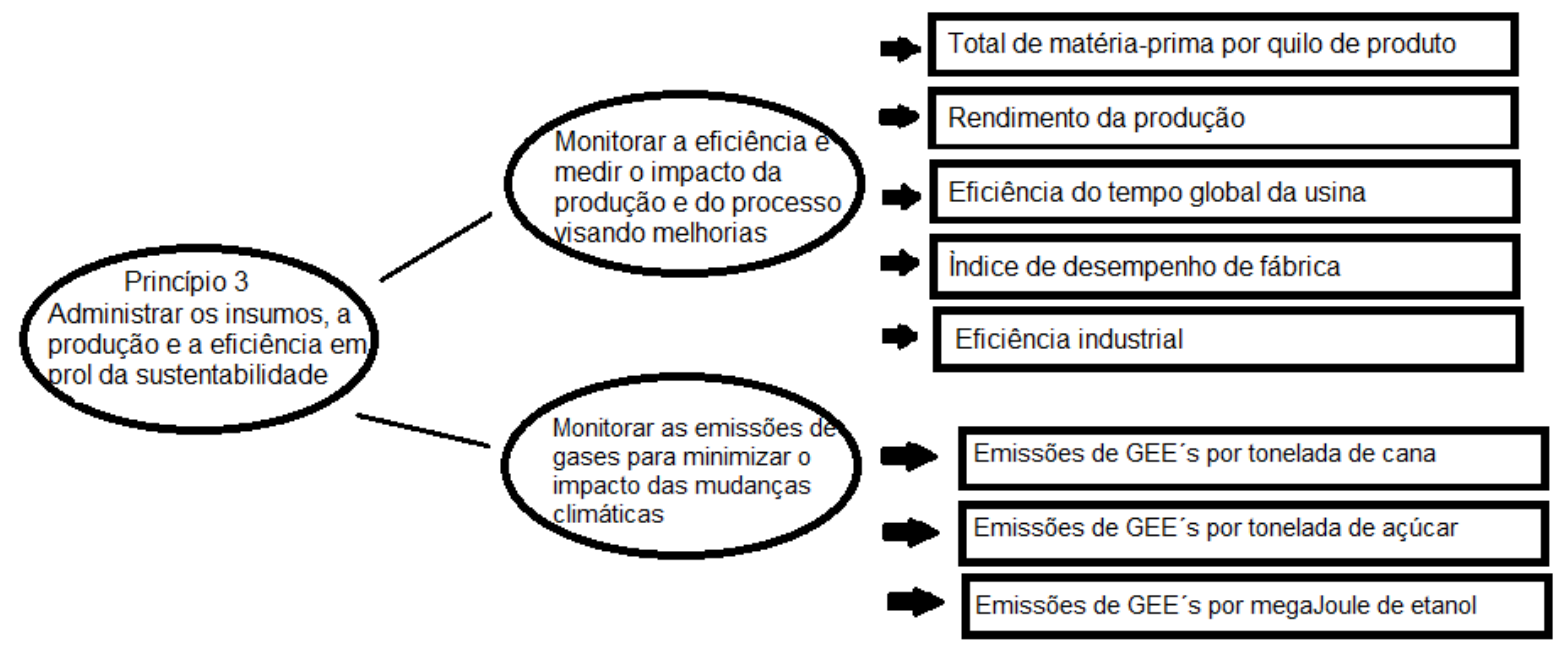

Fonte: Elaborado pelo ator com base no Guia para o Padrão de Produção Bonsucro 2015

No caso do primeiro critério, os indicadores se traduzem em: i) total de matériaprima por quilo de produto; ii) rendimento da produção em condições climáticas distintas; iii) a eficiência do tempo global da usina, encontrando a proporção em que a usina processa a cana com o tempo completo da estação; iv) o índice de desempenho da fábrica, atestado por quantos subprodutos a usina consegue $\operatorname{produzir}^{28}$ a partir da matéria-prima primordial: o melaço e v) a eficiência industrial, que é semelhante ao indicador anterior, mas levando em conta outras matérias-primas disponibilizadas a partir da cana-de-açúcar.

\footnotetext{
${ }^{28}$ Se apenas açúcar ou se também etanol e em que proporção.
} 
Para o segundo critério, que será reprisado mais adiante com outra configuração, os indicadores consistem apenas na emissão de gases do efeito estufa por tonelada de cana, por tonelada de açúcar e por megaJoule de etanol, permitindo localizar exatamente o balanço energético por produto.

No caso do quarto princípio (Figura 10), o único critério é o de avaliação do impacto da produção canavieira na biodiversidade e nos ecossistemas afetados. Para compor tal critério, os indicadores levantados são: i) oxigênio em cursos d'água afetados; ii) percentual de áreas de conservação ambiental mantidas pelo setor; iii) a existência ou não de um Plano de Gestão de Impacto Ambiental; iv) a proporção entre o índice de fertilizantes recomendado e aquele que é efetivamente aplicado; v) a quantidade de agroquímicos aplicados por hectare/por ano e vi) a quantidade de agroquímicos proibidos ${ }^{29}$ aplicados por hectare/por ano

\section{Figura 10 - Fluxograma de Critérios do BSI-Bonsucro para o Princípio IV -}

\section{Administração da Biodiversidade}

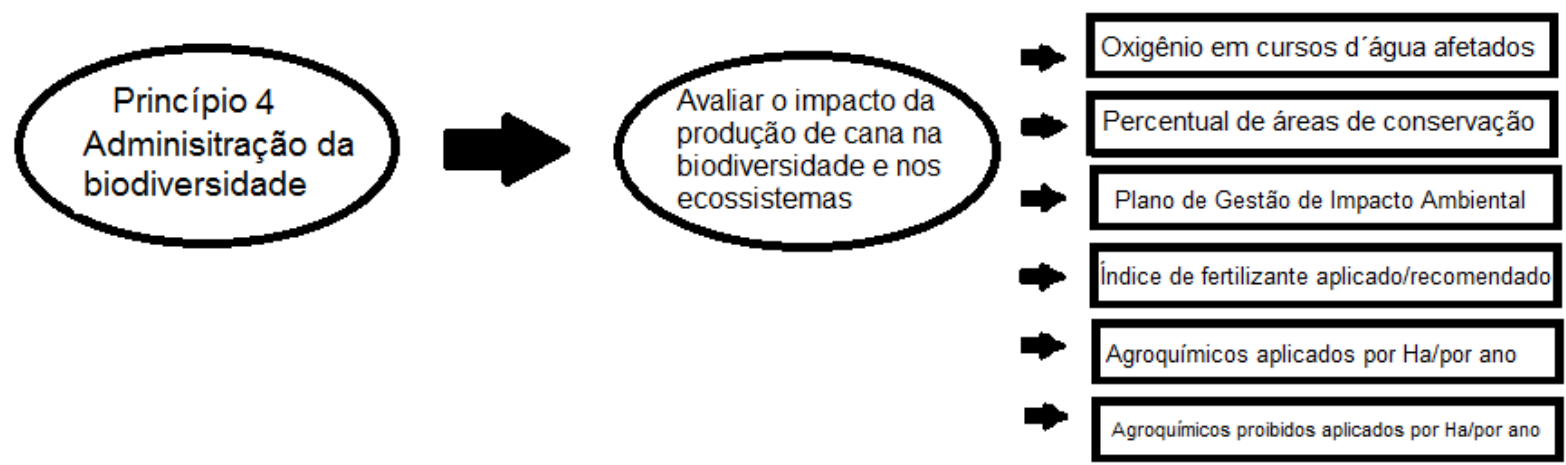

Fonte: Elaborado pelo ator com base no Guia para o Padrão de Produção Bonsucro 2015

O quinto princípio (Figura 11), pautado na melhoria das áreas-chave da cadeia, é aquele que se configura mais extenso em critérios e, por conseguinte, nos indicadores

\footnotetext{
${ }^{29}$ Para esclarecer seus membros, o Guia para o Padrão de Produção Bonsucro 2015 publica um anexo apenas com as substâncias proibidas, monitorando sua aplicação nas plantas certificadas.
} 
que os balizam. Nesse sentido, os critérios adotados são os seguintes: i) treinamento dos funcionários com fins de desenvolvimento de suas competências; ii) melhora contínua do status dos recursos do solo e das águas; iii) promover a eficiência energética; iv) reduzir as emissões e os efluentes oriundos da produção, promovendo a reciclagem de fluxos de resíduos onde for possível; v) melhorar continuamente a qualidade da cana e dos produtos dela derivados; vi) promover a pesquisa efetiva e focada, destinando um maior percentual das vendas a essa atividade; vii) assegurar processos transparentes, consultivos e participativos para avaliar o impacto socioambiental; viii) assegurar o engajamento nestes processos transparentes, consultivos e participativos para outras áreas interessadas e ix) promover a sustentabilidade econômica, buscando um aumento do valor agregado por tonelada de cana.

Figura 11 - Fluxograma de Critérios do BSI-Bonsucro para o Princípio V Melhora constante das áreas-chave

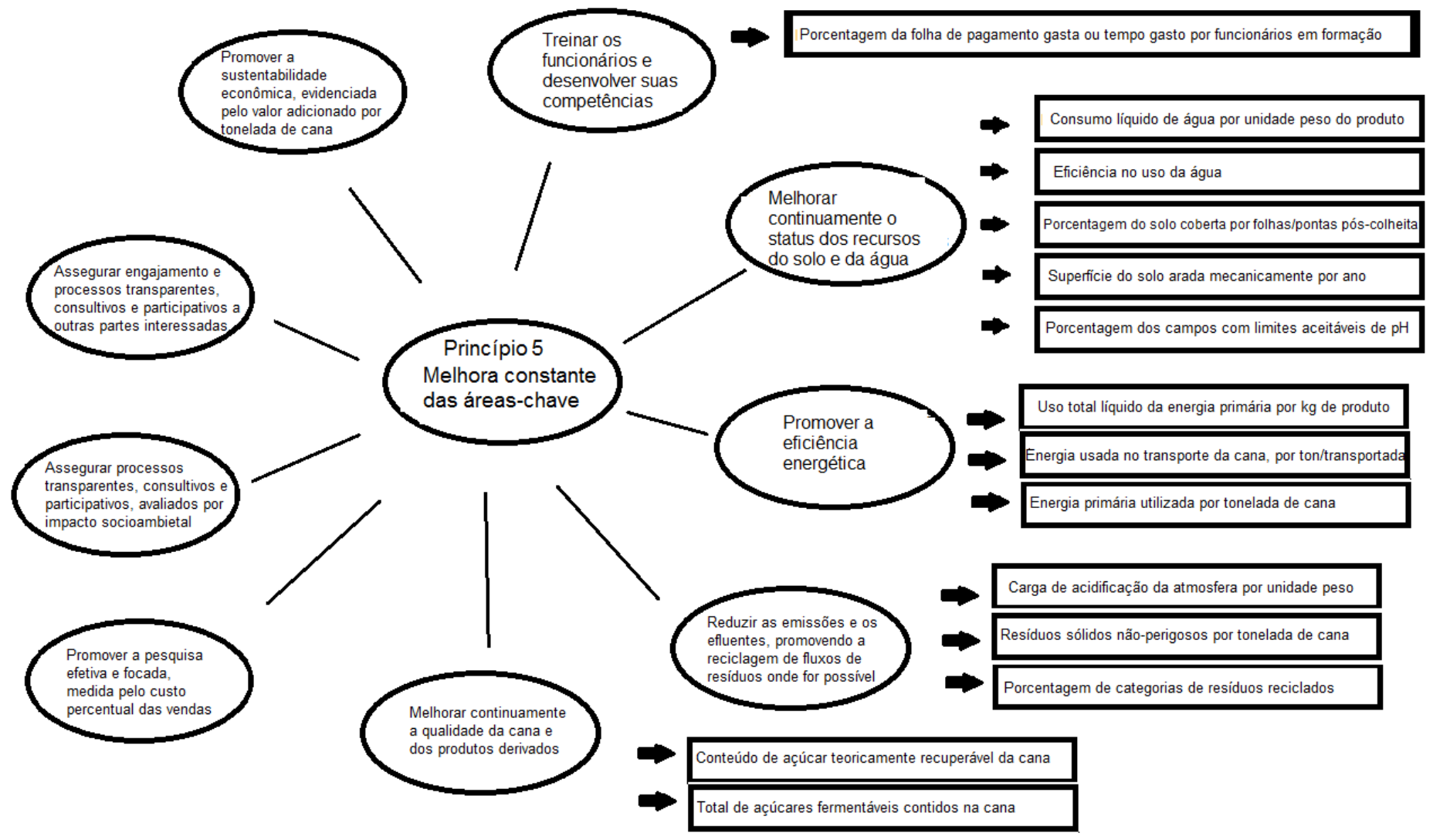

Fonte: Elaborado pelo ator com base no Guia para o Padrão de Produção Bonsucro 2015 
No que diz respeito ao primeiro critério, o indicador é apenas a percentagem da folha de pagamento ou do tempo gasto pelos funcionários em formações que desenvolvam suas competências. Já no que tange ao segundo critério, temos os seguintes indicadores: i) consumo líquido de água por unidade peso do produto em questão; ii) a eficiência no uso da água para a cadeia da cana; iii) a porcentagem de solo coberto por pontas e folhas após a colheita, devido ao percentual de nutrientes que enriquecem sua qualidade; iv) a extensão da superfície do solo arada mecanicamente por ano e v) a porcentagem dos campos com limites aceitáveis de acidez, medidos pelo respectivo $\mathrm{pH}$.

Para o terceiro critério, ligado à promoção da eficiência energética, os indicadores são: i) o uso total líquido de energia por $\mathrm{kg}$ de produto, ii) a energia utilizada no transporte da cana, medida por tonelada transportada e iii) a energia primária utilizada na cadeia de cana, para além daquela que já foi mensurada. No caso do quarto critério, outros três indicadores se fazem presentes: i) a carga de acidificação da atmosfera por unidade peso; ii) a quantidade de resíduos sólidos não perigosos por tonelada de cana e iii) a porcentagem de categorias de resíduos reciclados.

Observando o quinto critério, dois outros indicadores se fazem presentes, sendo este o último dos critérios desdobrado nesse quinto princípio: i) o conteúdo do açúcar teoricamente recuperável da cana e ii) o total de açúcares fermentáveis contidos na cana-de-açúcar.

Por fim, o sexto princípio, descrito na Figura 12 e adicionado para a adequação do BSI-Bonsucro à Diretiva de Renováveis promulgada pela União Europeia adotada em 2009, a qual, como já pontuamos, estabelece que $20 \%$ do consumo energético do bloco deve provir de fontes de energia renováveis até 2020, cujos critérios são: i) o monitoramento da emissão de gases do efeito estufa, visando minorar os impactos das mudanças climáticas - medido pela contribuição ao aquecimento global por unidade de energia e ii) a proteção de áreas com alto valor de biodiversidade, altos estoques de carbono e zonas úmidas. 
Figura 12 - Fluxograma de Critérios do BSI-Bonsucro para o Princípio VI Adequação à Diretiva de Renováveis promulgada pela União Europeia

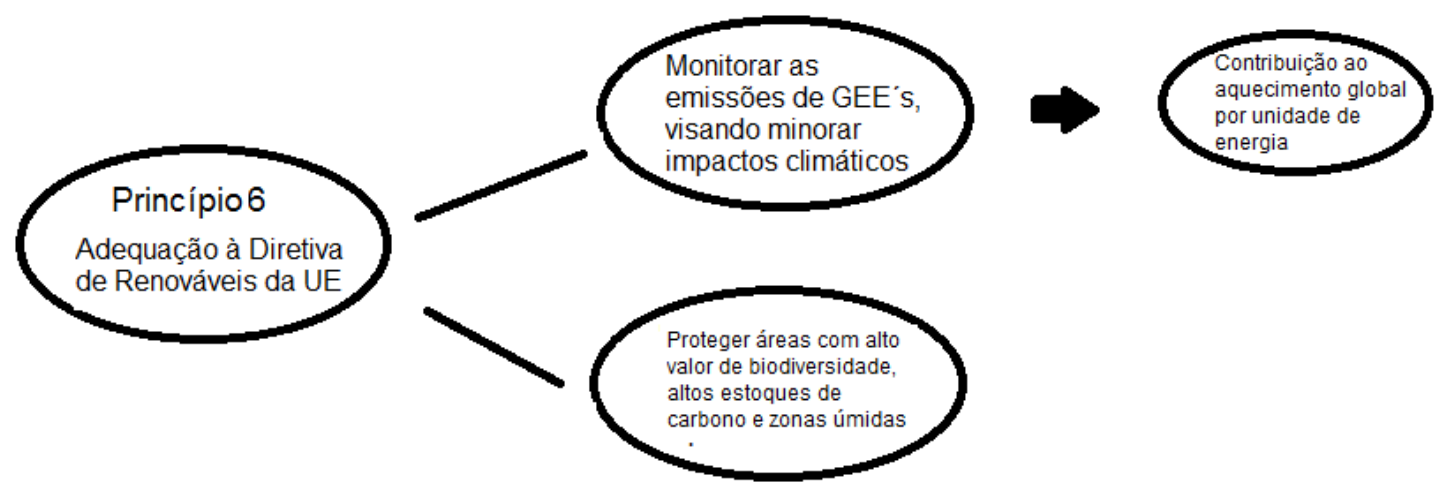

Fonte: Elaborado pelo ator com base no Guia para o Padrão de Produção Bonsucro 2015

Examinados os critérios de maneira pormenorizada, podemos nos debruçar sobre as características da iniciativa. Assim, com a prerrogativa de cumprir tais princípios e critérios, a organização conta, atualmente, com mais de 400 membros $^{30}$, espalhados por 44 países de todos os continentes, reunindo essencialmente: i) membros da sociedade civil (como a própria WWF), ii) traders (como a COSAN e a Copersucar), iii) conglomerados consumidores (como a Coca Cola, a Pepsi e a Ferrero), iv) grupos industriais (como a Raízen e a Bunge) e v) produtores e grupos agrícolas dos mais variados tamanhos e recursos.

Com base nos dados disponibilizados pela entidade, podemos observar os números expressos nas tabelas 3 e 4 e traçar algumas considerações. Em primeiro lugar, no que diz respeito ao país de origem dos membros, salta aos olhos a preponderância dos países chamados emergentes, notadamente Índia e Brasil, que, sozinhos, perfazem mais de $75 \%$ dos membros.

Para além destes dois países, Austrália, Colômbia, Estados Unidos da América e Reino Unido são aqueles que detêm o maior número de organizações que aderem ao

\footnotetext{
${ }^{30}$ A lista com todos os 487 membros está disponível no Anexo 1 deste trabalho.
} 
arranjo, seguidos por Holanda, Paquistão, Indonésia, Bolívia, Canadá, El Salvador, Suíça, França, México, Paquistão, Indonésia, México, Suíça, Tailândia, Suazilândia, África do Sul, Itália, Honduras, Maurício Nicarágua, Japão, Espanha, Indonésia, Argélia, Bélgica, Camboja, Cingapura, Dinamarca, Fiji, Guatemala, Luxemburgo, Malawi, República Dominicana, Tailândia, Suécia, Sudão, Uganda, Argentina, Filipinas, Bósnia e Herzegovina, Áustria, Israel e Emirados Árabes Unidos.

Tabela 3 - Número de membros por país de origem no BSI-Bonsucro

\begin{tabular}{|c|c|}
\hline País de origem & $\begin{array}{r}\text { Número de } \\
\text { membros }\end{array}$ \\
\hline Argélia & 1 \\
\hline Argentina & 1 \\
\hline Austrália & 14 \\
\hline Bolívia & 3 \\
\hline $\begin{array}{c}\text { Bósnia e } \\
\text { Herzegovina }\end{array}$ & 1 \\
\hline Brasil & 129 \\
\hline Bélgica & 1 \\
\hline Camboja & 1 \\
\hline Canadá & 3 \\
\hline China & 2 \\
\hline Cingapura & 1 \\
\hline Colômbia & 14 \\
\hline Dinamarca & 1 \\
\hline El Salvador & 3 \\
\hline $\begin{array}{c}\text { Emirados Árabes } \\
\text { Unidos }\end{array}$ & 1 \\
\hline Espanha & 1 \\
\hline EUA & 13 \\
\hline Fiji & 1 \\
\hline França & 4 \\
\hline Filipinas & 1 \\
\hline
\end{tabular}




\begin{tabular}{|cc|}
\hline Guatemala & 1 \\
\hline Holanda & 6 \\
\hline Honduras & 2 \\
\hline Indonésia & 5 \\
\hline Israel & 1 \\
\hline Itália & 2 \\
\hline Japão & 1 \\
\hline Luxemburgo & 1 \\
\hline Malawai & 1 \\
\hline Maurício & 2 \\
\hline México & 4 \\
\hline Nicarágua & 3 \\
\hline Paquistão & 6 \\
\hline Reino Unido & 12 \\
\hline Rep. Dominicana & 1 \\
\hline Suazilândia & 3 \\
\hline Sudão & 1 \\
\hline Suécia & 1 \\
\hline Suíça & 4 \\
\hline Tailândia & 4 \\
\hline Uganda & 1 \\
\hline África do Sul & 3 \\
\hline Áustria & 1 \\
\hline India & 225 \\
\hline Total & 487 \\
\hline
\end{tabular}

Fonte: elaborada pelo autor com dados da BSI-Bonsucro (2016)

Já no que diz respeito aos dados do setor originário de cada membro, expostos na tabela e no gráfico abaixo, a preponderância clara fica com o agronegócio que, entre fazendas e usinas, soma mais de $70 \%$ do total, seguido, de longe, pelos conglomerados industriais, pelos traders, pelas entidades da sociedade civil e, enfim, pelos consumidores finais. 
Tabela 4 - Número de membros por setor no BSI-Bonsucro

\begin{tabular}{lcc}
\hline Setor & $\begin{array}{c}\text { Número } \\
\text { membros }\end{array}$ \\
\hline Trader & 41 \\
\hline Sociedade Civil & 22 \\
\hline Indústria & 62 \\
Agronegócio & 342 \\
Consumidor & 20 \\
\hline TOTAL & 487 \\
\hline
\end{tabular}

Fonte: elaborada pelo autor com dados da BSI-Bonsucro (2016)

Ao avançar na análise desta iniciativa de certificação, é importante registrar que sua abrangência tem crescido não apenas em número de membros. Desde 2011, quando o BSI-Bonsucro passou a monitorar e certificar as lavouras de cana-de-açúcar para produção de açúcar e etanol, o volume e área plantada de cana certificada tiveram um salto, chegando atualmente a 970,4 mil hectares e 58,4 mil toneladas ${ }^{31}$, conforme expresso no gráfico 7 e em número de usinas certificadas, chegando a $47^{32}$.

\footnotetext{
${ }^{31}$ A despeito de parecerem números vultosos, estes totais correspondem apenas a 4,08\% da área e 3,52\%, respectivamente, do total de área cultivada e de cana produzida no globo, o que não minimiza a iniciativa, dada a profusão de concorrentes e o crescimento constante desde que iniciou as atividades.

${ }^{32}$ No último ano houve novas certificações, mas como as informações ainda não estavam disponibilizadas de maneira completa no site da instituição, optamos por utilizar, para esse caso, as estatísticas do ano anterior.
} 
Gráfico 7 - Volume e área de cana-de-açúcar certificada no BSI-Bonsucro (20112015)

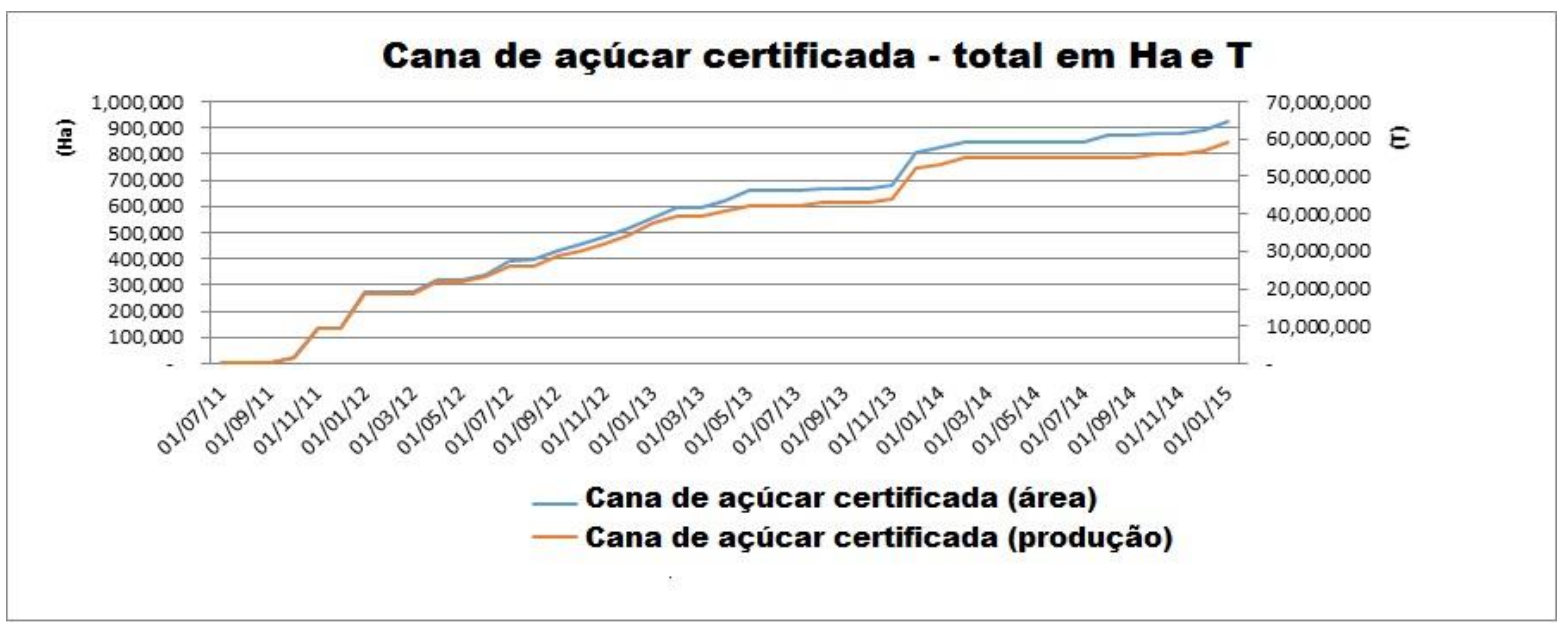

Fonte: adaptado pelo autor com dados da BSI-Bonsucro (2015)

Os dados da tabela 5 mostram que, do total de usinas certificadas, o Brasil ocupa a primeira posição de maneira inconteste com 40 usinas, seguido da Austrália com 5 usinas e da Índia e Honduras, com uma usina cada. No que diz respeito aos grupos empresariais, listados na tabela 6, a liderança ficou com a Raízen com 12 usinas, seguida pela Copersucar com 7, pela Bunge com 4, pelos grupos Odebrecht, Guarani e New South Wales com 3 usinas cada, pelos grupos Adecoagro, São Martinho e Bundaberg com 2 usinas cada e, por fim, por Marugappa, CMAA, SAB Miller, BP Tropical, Noble Group, LDC, Alta Mogiana, Usina São João e Junqueira com 1 usina cada. 
Tabela 5 - Número de usinas certificadas por país no BSI-Bonsucro

\begin{tabular}{lcc}
\hline País & $\begin{array}{l}\text { Número } \\
\text { usinas }\end{array}$ & de \\
\hline Brasil & 40 \\
Austrália & 5 \\
Índia & 1 \\
Honduras & 1 \\
TOTAL & 47 \\
\hline
\end{tabular}

Fonte: elaborada pelo autor com dados da BSI-Bonsucro (2015)

Outra forma de observar a ascensão da BSI-Bonsucro no âmbito da certificação é tomar as medidas de seus principais produtos finais, ou seja, o açúcar e o etanol, desde 2011 até os últimos dados consolidados de 2013. O gráfico 8 mostra que a quantidade tanto de açúcar como de etanol certificados tiveram um expressivo incremento, sendo o de próximo de 1 milhão de megatoneladas para o açúcar e praticamente o dobro para o etanol.

Gráfico 8 - Volume de açúcar e etanol de cana-de-açúcar certificados no BSIBonsucro (2011-2013) - em megatoneladas

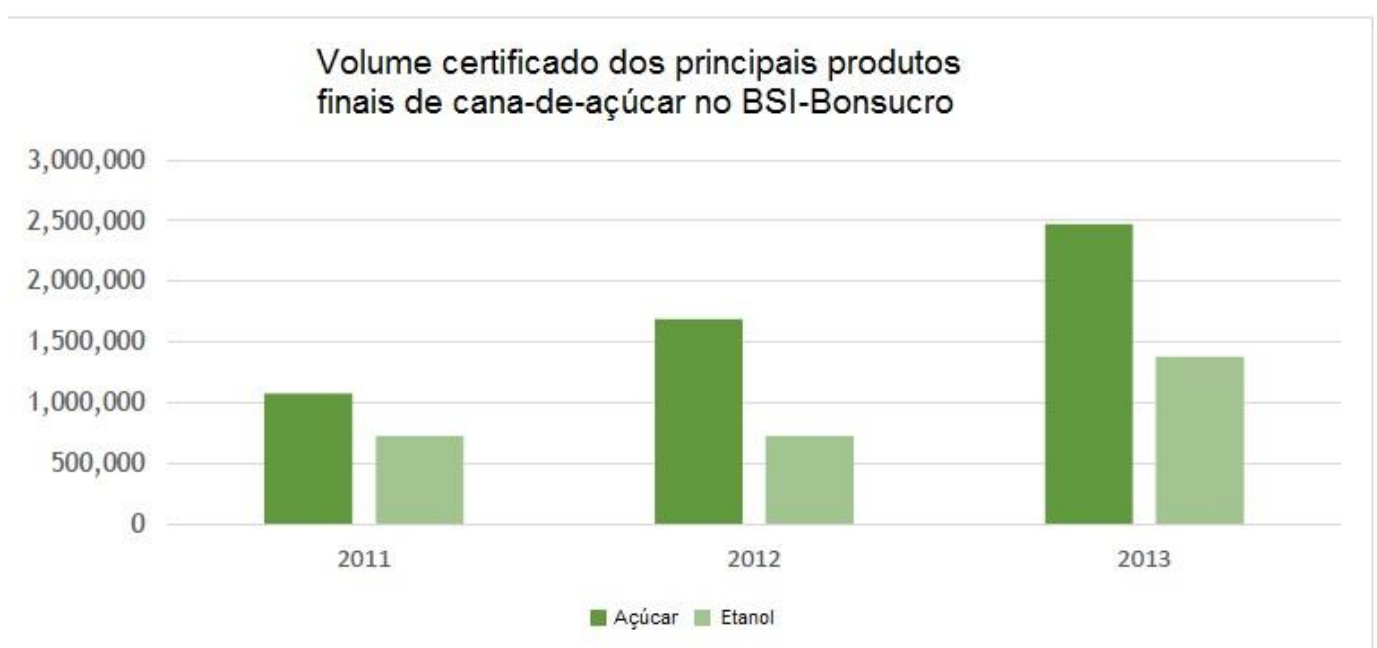

Fonte: Guia para o Padrão de Produção Bonsucro 2015 
Tabela 6 - Número de usinas certificadas por grupo empresarial no BSI-Bonsucro

\begin{tabular}{|c|c|}
\hline Grupo & $\begin{array}{l}\text { Número de } \\
\text { usinas }\end{array}$ \\
\hline Raízen & 12 \\
\hline Copersucar & 7 \\
\hline Bunge & 4 \\
\hline Odebrecht & 3 \\
\hline Guarani & 3 \\
\hline $\begin{array}{ll}\text { New South } \\
\text { Wales }\end{array}$ & 3 \\
\hline Adecoagro & 2 \\
\hline São Martinho & 2 \\
\hline Bundaberg & 2 \\
\hline Murugappa & 1 \\
\hline СМАA & 1 \\
\hline SAB Miller & 1 \\
\hline BP - Tropical & 1 \\
\hline Noble Group & 1 \\
\hline LDC & 1 \\
\hline Alta Mogiana & 1 \\
\hline $\begin{array}{l}\text { Usina São } \\
\text { João }\end{array}$ & 1 \\
\hline Junqueira & 1 \\
\hline
\end{tabular}

Fonte: elaborada pelo autor com dados da BSI-Bonsucro (2015)

\subsection{Estrutura institucional e governança}

De posse das informações da história e das características, voltamos agora nossa atenção para a estrutura institucional e a governança do BSI-Bonsucro. Nesse sentido, é necessário esclarecer que a Bonsucro buscou constituir-se com uma estrutura institucional e uma governança próprias, ambas alicerçadas nos princípios e normativas 
da Aliança Internacional de Acreditação e Certificação Social e Ambiental (ISEAL, na sigla em inglês $)^{33}$.

Uma vez que se torne associada, a organização pode pleitear ser certificado pela BSI-Bonsucro, embora não seja algo mandatório para estes membros. Desta forma, conforme já demonstramos, há muito mais integrantes que certificados expedidos. Ademais, é importante pontuar que a filiação dos membros é voluntária e aberta, desde que sejam entidades que façam parte da cadeia de cana ou nela se mostrem interessadas, condicionadas à aprovação daqueles que já compõem a iniciativa.

Desta forma, o caminho para se tornar parte do arranjo segue o esquema da Figura 13 abaixo: i) o candidato deve começar preenchendo um cadastro, disponibilizando suas informações institucionais e expondo as razões pelas quais deseja integrar a iniciativa; ii) em seguida, é preciso que o candidato assine o código de conduta da iniciativa e revele seus balanços contábeis, a fim de que se calcule a contribuição anual obrigatória que irá aportar junto à instituição ${ }^{34}$; iii) cumpridas tais etapas, os cadastros são postados na intranet da BSI-Bonsucro e ficam sujeitos à avaliação dos demais membros por 30 dias para que estes possam se manifestar sobre a eventual candidatura; iv) por fim, caso não haja quaisquer objeções, os diretores têm a palavra final para aprovar ou não a candidatura em questão, cabendo recursos dos candidatos para eventuais queixas durante o processo.

\footnotetext{
${ }^{33}$ A ISEAL - International Social and Enviromental Accreditation and Labeling Alliance - é uma espécie de parâmetro de sustentabilidade que norteia as iniciativas de certificação para padrões de sustentabilidade em diversos setores agrícolas, florestais, pesqueiros, entre outros.
}

\footnotetext{
${ }^{34}$ A taxa mensal cobrada dos membros é calculada de acordo com a natureza e dimensão da organização bem como da posição sócio-econômica do país de origem, com vistas a incentivar a participação de membros de países emergentes.
} 
Figura 13 - Esquema para filiação das organizações no BSI-Bonsucro

Preencher o cadastro e revelar informações da organização e razões para filiação na iniciativa.

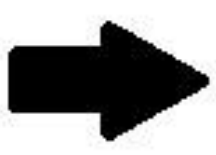

Assinar o código de conduta da iniciativa e revelar informações contábeis para aferir a taxa de mensalidade.
Caso não haja objeção, que podem ser respondidas, os diretores têm a palavra final sobre a candidatura.

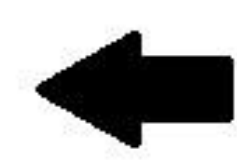

Os cadastros são postados na intranet e os membros tem 30 dias para se manifestarem sobre a candidatura.

Fonte: elaborada pelo autor com dados da BSI-Bonsucro (2015) e Chaddad e Moura (2012).

De acordo com Mallet e Smith (2007), para além das características do processo de admissão, a governança sob a qual a iniciativa se pauta é de fundamental importância para compreender e legitimar o processo decisório de uma instituição, o engajamento de cada grupo e a correlação de forças entre eles.

Assim sendo, vale esclarecer que o modelo engendrado pela instituição em 2009 foi inspirado em uma estrutura semelhante às empresas privadas em que cada um dos membros é representado por um conselho de diretores e possui, independente de seu tamanho ou da taxa de mensalidade que aporta, um voto para eleger esses representantes.

Atualmente, este conselho é composto de 12 diretores, eleitos anualmente em um encontro de todos os membros e respeitando a regra de haver pelo menos um diretor 
de cada um dos diversos setores que compõem os membros da iniciativa ${ }^{35}$, sendo que desse corpo de diretores deve emergir um presidente e vice eleitos entre os pares. $\mathrm{O}$ poder deste conselho é bastante significativo, cabendo a ele: i) representar os interesses dos associados; ii) tomar as decisões sobre todos os aspectos da iniciativa, sendo algumas cruciais como a admissão de novos membros e os critérios da certificação e iii) criar e coordenar as atividades dos comitês, que hoje são em número de quatro (Certificação, Comunicação, Apelação e Governança).

Além do conselho e dos comitês, a BSI-Bonsucro possui, nos moldes de uma organização internacional, um Secretariado Executivo responsável pela operação diária da iniciativa e formado por um Diretor Executivo, um Diretor de Engajamento e Comunicação, um Diretor de Sustentabilidade, um Coordenador para a Certificação, um Gerente de Operações e um Gerente para Internet.

Por fim, existe o braço científico da iniciativa, formado pelos Grupos de Trabalho Técnico que congregam especialistas de várias nacionalidades e formações com vistas a desenvolver e melhorar os critérios de certificação em três principais subgrupos: i) questões sociais e trabalhistas, ii) questões agronômicas e iii) processamento agrícola sustentável. Com base no trabalho desses grupos, o BSIBonsucro atualmente dispõe de 28 critérios de sustentabilidade, aferidos por meio de 69 indicadores para medir seu cumprimento.

Ao enunciarmos este número de critérios e indicadores, fica patente a necessidade de esclarecer o primeiro passo do processo de certificação, ou seja, como determinados critérios se tornam parte dessa iniciativa, tornando-se parte dos requisitos para que um membro receba o "certificado" do BSI-Bonsucro.

Nesse sentido, utilizaremos a próxima seção para descrever o processo de certificação, sua evolução ao longo do tempo e suas características e distinções entre os dois tipos de certificados expedidos pelo arranjo em questão.

\footnotetext{
35 Tradicionalmente, desde que a instituição consolidou o formato deste conselho em 2010, quando fundiu os antigos conselho supervisor e comitê de gestão, os membros acabam subdivididos entre quatro do setor industrial e dois dos demais setores (agronegócio, traders, sociedade civil e consumidores finais).
} 


\subsection{O processo de certificação}

Em primeiro lugar, são estabelecidos os procedimentos, com base em uma consulta pública na intranet por dois períodos de sessenta dias, em que é possível aos membros fazerem comentários e reparos ao pretenso mecanismo. Após esse período, registram-se os comentários em uma espécie de resumo público, avaliado pelos diretores que dão a palavra final sobre quais critérios devem vigorar e quais serão descartados.

De acordo com um importante documento interno da iniciativa - o Guia para o Padrão de Produção 2015 - as últimas revisões de critérios se deram em seis reuniões, intercaladas entre encontros presenciais (I- Londres em Novembro de 2012, III - Nova Orleans em Novembro de 2013 e V- Nova Deli em Fevereiro de 2014) e encontros online (II de Janeiro a Março de 2013, IV de Dezembro de 2013 a Janeiro de 2014 e VI em Junho de 2014).

Com base nestas reuniões de membros, os critérios adotados pelo BSI-Bonsucro já sofreram várias alterações ao longo dos anos, sendo algumas revisões preliminares e outras mais estruturais, conforme podemos observar no quadro 8, abaixo: 


\section{Quadro 8 - Datas das revisões dos critérios da certificação BSI-Bonsucro}

\begin{tabular}{|c|c|c|}
\hline Revisão & Data & Descrição da alteração \\
\hline A & Junho de 2010 & $\begin{array}{l}\text { Versão preliminar enviada para o Subcomitê da Bonsucro da } \\
\text { UE }\end{array}$ \\
\hline B & Julho de 2010 & Versão final aprovada pelo Comitê de Gestão da Bonsucro \\
\hline C & Dezembro de 2010 & Revisão feita com base na conformidade com a RED da UE \\
\hline D & Fevereiro de 2011 & Revisão feita com base na conformidade com a RED da UE \\
\hline Versão preliminar 2.0 & Novembro de 2013 & Primeiro esboço aberto para reuniāo pública \\
\hline Versão preliminar 2.5 & Junho de 2014 & Segundo esboço aberto para reunião pública \\
\hline Versão preliminar 2.9 & Julho de 2014 & Esboço final aberto para reunião pública \\
\hline Versāo 4 & Julho de 2014 & $\begin{array}{l}\text { Padrāo de Produção e Guia da Bonsucro revisados, } \\
\text { com a inclusão de novos indicadores e esclarecimentos } \\
\text { acrescentados, tornaram-se uma orientação para a } \\
\text { implementação. } \\
16 \text { indicadores principais em oito (8) critérios } \\
12 \text { novos indicadores (acrescentados ou substituindo outros } \\
\text { indicadores) } \\
2 \text { indicadores cujo valor foi modificado } \\
2 \text { indicadores retirados } \\
\text { Exclusão do Princípio } 7 \text { - Cadeia de Custódia }\end{array}$ \\
\hline Versão 4.01 & Outubro de 2014 & $\begin{array}{l}\text { Correção de erros mostrados no indicador } 2.1 .4 \text { e definição } \\
\text { AVC (apenas na versão em Inglês) }\end{array}$ \\
\hline Versāo 4.1 & Agosto de 2015 & $\begin{array}{l}\text { Principio revisado } 6 \text { a incluir certificação de etanol } \\
\text { celulósico produzido a partir de derivados da cana de } \\
\text { açucar (por exemplo, palha e bagaço) no escopo de } \\
\text { certificação da Bonsucro EU. } \\
\text { Além disso, alterações adicionais não substanciais feitas } \\
\text { para indicadores } 5.2 .4 \text { e } 2.3 .4 \text {. }\end{array}$ \\
\hline Versão 4.1.1 & Setembro de 2015 & $\begin{array}{l}\text { Indicador } 6.1 .2 \text { revisto para incluir uma definição dos terrenos } \\
\text { de pastagem ricos em biodiversidade, em conformidade com o } \\
\text { Regulamento UE n. } 1307 / 2014 \text {. }\end{array}$ \\
\hline
\end{tabular}

Fonte: Guia para o Padrão de Produção Bonsucro 2015

Como podemos perceber por estes dados coletados do Guia para o Padrão de Produção Bonsucro 2015, as mudanças realmente significativas ocorreram em julho de 2014 e se estenderam para 2015, buscando adequar-se a normativas internacionais (notadamente a Diretiva da União Europeia para Renováveis) e utilização de novos subprodutos como o bagaço e a palha de cana. 
Assim, atualmente, para que um determinado membro seja considerado apto a receber o "selo" da iniciativa, é necessário que este se comprometa com os cinco princípios já citados em, pelo menos, $80 \%$ de sua produção e manejo. Nesse sentido, é necessária uma terceira-parte para fiscalizar tal cumprimento a fim de garantir um real compliance dos atores, a qual é composta por sete comitês independentes de auditores externos reconhecidos para a tarefa.

Uma vez expedido o certificado, sua validade é de três anos, mas o monitoramento permanece constante a cada safra de cana, mantendo um processo em que é possível ao candidato obter dois tipos de "selo" certificador: in product ou off product, conforme o quadro comparativo abaixo:

\section{Quadro 9 - Dois tipos de certificação expedidos pelo BSI-Bonsucro}

\begin{tabular}{|c|c|}
\hline Certificação In Product & Certificação Off Product \\
\hline $\begin{array}{c}\text { Certificação que incide apenas sobre } \\
\text { corporações que utilizam a cana-de-açúcar } \\
\text { como insumo. }\end{array}$ & $\begin{array}{c}\text { Certificação que incide sobre qualquer } \\
\text { membro da cadeia de cana-de-açúcar que } \\
\text { compõe a iniciativa }\end{array}$ \\
\hline $\begin{array}{c}\text { Uma vez certificada, a entidade pode } \\
\text { utilizar o selo de certificação BSI- } \\
\text { Bonsucro em seus produtos para o } \\
\text { mercado global. }\end{array}$ & $\begin{array}{c}\text { Uma vez certificada, a entidade pode } \\
\text { apenas informar internamente ao BSI- }\end{array}$ \\
\hline \multicolumn{2}{|c|}{ Ambas as certificações demandam o pagamento de taxas } \\
\hline
\end{tabular}

Fonte: elaborada pelo autor com dados da BSI-Bonsucro (2015) e Chaddad e Moura (2012).

Observando o quadro 9, é possível perceber que existem duas certificações possíveis no caso da iniciativa BSI-Bonsucro. a primeira, denominada in product, consistindo no caso clássico de certificação sobre o insumo, provendo o selo para o mercado global de cana, enquanto que a segunda, denominada off product, apenas servindo como uma sinalização interna à iniciativa para os membros da BSI-Bonsucro. Cabe ressaltar que a única semelhança estaria ligada ao fato de que ambas não seriam concedidas gratuitamente, gerando uma taxa para sua concessão. 
A despeito de tal estrutura, o processo de certificação BSI-Bonsucro não é livre de críticas e ainda gera controvérsias entre seus analistas, muito bem resumidas no trabalho de Rein (2009). Nele, o autor avalia que as limitações da iniciativa estão ligadas, em primeiro lugar, ao escopo da certificação que, apesar de exaustivo, ainda deixava de fora questões técnicas como o uso indireto da terra e a ascensão dos preços de alimentos que impacta a escolha das usinas entre a produção de açúcar e de etanol.

Para além da abrangência, as iniciativas de certificação sofrem críticas por um suposto problema de credibilidade com relação ao cumprimento de seus critérios, dado que a fiscalização é promovida pelos próprios membros ou entidades associadas a eles. Tal questão é agravada pelo fato de que os critérios não podem ser estanques, mas precisam estar em constante renovação e adaptação a realidades geográficas e culturais distintas, conforme já vimos na revisão bibliográfica.

Com base nestas limitações de funcionamento e nas questões suscitadas sobre a coordenação de interesses nas iniciativas de certificação, buscaremos utilizar o próximo e último capítulo para verificar as questões associadas à ação coletiva presentes nestes esquemas, examinando o quadro teórico e aplicando o modelo a ele associado. 


\section{CAPÍTULO 4: A AÇÃO COLETIVA NO MODELO DE GOVERNANÇA NA CERTIFICAÇÃO DA CANA}

\subsection{A ação coletiva como problema na Ciência Política}

Como afirmamos já no capítulo 1, após a revisão bibliográfica acerca do tema da governança privada internacional, as iniciativas de certificação guardam uma importante relação com a problemática da ação coletiva. Nesse sentido, precisamos compreender a teoria clássica acerca da ação coletiva para, em seguida, compreender os avanços da contribuição de Elinor Ostrom à luz do caso em tela, exposto no capítulo anterior

A questão da ação coletiva começou a ser sistematicamente estudada na Ciência Política a partir da contribuição seminal de Mancur Olson (1971) onde o autor utilizou modelos econômicos para compreender o comportamento e a dinâmica de grupos sociais ${ }^{36}$. Olson utiliza os conceitos de utilidade marginal da teoria econômica neoclássica e os conceitos de bens públicos desenvolvidos pelo economista Paul Samuelson (1954) para estabelecer uma explicação coerente para o tema, a qual pode ser sumarizada na taxonomia de grupos enunciada no Quadro 10.

Samuelson enuncia o conceito de bens públicos por meio de uma interação entre duas variáveis: a rivalidade e a exclusividade, conforme a Figura 14. Assim, em primeiro lugar, o conceito de bens rivais, são aqueles cujo consumo reduz a quantidade disponível desse bem para o restante da sociedade, sendo seu oposto chamado de bem não-rival.

Já o conceito de exclusividade está ligado à possibilidade de se impedir - ou não - alguém de ter acesso a determinado bem, seja por questões jurídicas, sócioeconômicas, políticas ou mesmo naturais. Nesse sentido, para Samuelson, quando um bem é simultaneamente rival e excludente, trata-se de um bem privado. Já quando um bem é rival, mas não excludente, estamos diante de um recurso comum, enquanto que o oposto - um bem excludente, mas não-rival - evoca a ideia de um monopólio natural.

\footnotetext{
${ }^{36}$ As interpretações sobre os grupos sociais até a publicação de "A Lógica da Ação Coletiva” de Mancur Olson eram mais ligadas à Sociologia, com pouca ou nenhuma formalização, carecendo de empiria e dados em detrimento de explicações mais generalistas. É importante ressaltar que a teoria olsoniana busca uma compreensão geral dos grupos sociais, mas busca associar ao seu comportamento no mercado, evidenciando a equivalência entre as categorias em sua taxonomia.
} 
Por fim, há aqueles bens que não são nem rivais, nem excludentes - ou seja, aqueles que não se pode impedir o acesso e cuja utilização por um não gera necessariamente uma redução na quantidade para os demais membros da sociedade aos quais se convencionou chamar de bens públicos.

Figura 14 - Rivalidade e exclusividade em Samuelson (1954)

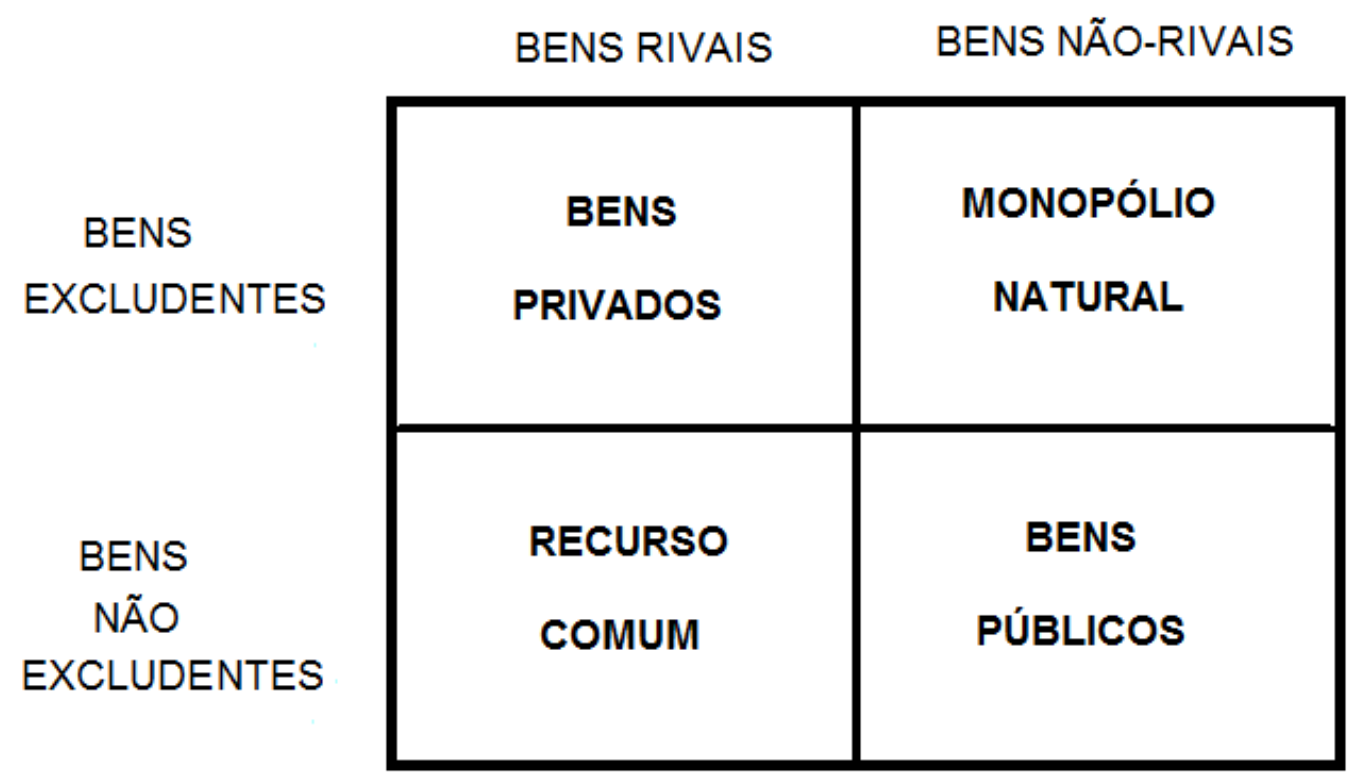

Fonte: elaboração do autor, a partir de Samuelson (1954)

Para facilitar a compreensão desta tipologia, costuma-se trazer exemplos referentes a cada uma das categorias expostas. Desta forma, os bens privados seriam todos aqueles bens e serviços frutos de um contrato que garante a posse como uma caneta ou um automóvel. No caso do monopólio natural, conhecido também como bens de clube, podemos ilustrá-los com exemplos prosaicos como um serviço de televisão por assinatura ou um vigilante noturno de rua que podem excluir os que não são clientes, mas cujo aumento de mais um cliente não implica na diminuição/piora do serviço para os demais.

Os recursos comuns seriam exemplificados pelos peixes no mar ou por uma vasta pastagem onde não seria possível excluir aqueles que busquem alimentos para si 
ou para seu rebanho, mas cuja utilização necessariamente impede ou diminui o acesso de outros. ${ }^{37}$

Para concluir, os bens públicos teriam como exemplo a defesa nacional ou uma exibição de fogos de artifício em uma praia cuja fruição não pode ser impedida e nem prejudica ou diminui a fruição dos demais, mas cujo controle também acaba sendo bastante complexo, dando origem a um problema denominado "problema do carona" ou, no original em inglês, free-rider problem ${ }^{38}$.

Utilizando esta tipologia, Mancur Olson argumenta que diante de um bem público, o indivíduo racional pode preferir não cooperar para garanti-lo, assumindo justamente um comportamento de caroneiro. Nesse sentido, em grupos numerosos o suficiente para que a contribuição individual para a produção deste bem (público) não seja notada - denominados pelo autor como grupos latentes - residiria a chave para a compreensão do "dilema da ação coletiva".

Neste dilema, a ideia seria que se todos os membros do grupo buscassem maximizar sua utilidade e deixassem de dar sua contribuição por entendê-la como desprezível para auferir o bem, o resultado no agregado seria desastroso e o bem público em questão acabaria por deixar de ser produzido.

Dessa forma, Olson pontua que a cooperação seria mais natural em grupos menores, onde se evidencia mais facilmente o comportamento do caroneiro, sendo possível minimizar seus efeitos. Já no caso de grupos maiores, seria necessária a aplicação de incentivos seletivos positivos (benesses ou estímulos) e negativos (sanções) para estimular a cooperação que não seria natural nem racional.

Observando a questão das razões que levam à cooperação mesmo nos grandes grupos, Olson identifica que os membros efetuam um cálculo de custo-benefício para decidir se contribuem com o bem coletivo e em que medida. Diante da assimetria dos membros, pode haver um membro grande que busque, por interesse próprio, arcar com todo o custo da cooperação, dando origem aos chamados grupos privilegiados. Nesses

\footnotetext{
${ }^{37}$ Devido às características deste tipo de bens, alguns autores debruçaram-se sobre seu estudo como Garret Hardin, e, mais recentemente, Elinor Ostrom, como veremos mais adiante.

${ }^{38} \mathrm{O}$ problema do carona ou free-rider consiste no fato de um determinado conjunto de indivíduos pagar por um bem que gera externalidades positivas para outros que não pagaram. Nesse sentido, constata-se que como é possível usufruir de um bem sem incorrer em custos para tal, há um incentivo para que os indivíduos assumam tal comportamento. (Olson, 1971)
} 
grupos, dá-se um fenômeno bastante interessante: a exploração do grande pelo pequeno, ou seja, a assunção por parte de um membro grande de uma parte do custo de provimento do bem coletivo maior do que as vantagens proporcionadas a ele. Do ponto de vista dos membros pequenos, a exploração é racionalmente lógica, pois um membro pequeno sempre alcança uma parcela menor do bem coletivo, além de permitir a ele que obtenha mais do bem coletivo do que jamais poderia conseguir sozinho.

Por fim, haveria os grupos intermediários onde não há um membro grande com interesses suficientes para arcar sozinho com os custos da cooperação, mas tampouco o grupo é grande o suficiente para que o comportamento de carona não seja percebido, tornando incerta a provisão do bem coletivo.

Quadro 10 - Taxonomia dos grupos em Olson (1971)

\begin{tabular}{|c|c|c|c|}
\hline \multicolumn{4}{|c|}{ GRUPOS/ORGANIZAÇŌES } \\
\hline \multicolumn{2}{|c|}{ Inseridos no Contexto do Mercado } & \multicolumn{2}{|c|}{ Não Inseridos no Contexto do Mercado } \\
\hline $\begin{array}{l}\text { Monopólio } \\
\text { puro }\end{array}$ & $\begin{array}{l}\text { Situação onde há } \\
\text { somente uma empresa } \\
\text { no setor industrial }\end{array}$ & Indivíduo & $\begin{array}{l}\text { Situação em que um único individuo visa um } \\
\text { beneficio coletivo }\end{array}$ \\
\hline \multirow[t]{2}{*}{ Oligopólio } & \multirow{2}{*}{$\begin{array}{l}\text { Situação em que as } \\
\text { empresas são tão } \\
\text { poucas que as ações de } \\
\text { uma tem um efeito } \\
\text { perceptivel } \\
\text { qualquer outra empresa } \\
\text { ou grupo de empresas. }\end{array}$} & Privilegiados & $\begin{array}{l}\text { Situação em que cada pelo o menos um dos } \\
\text { membros tem incentivo para se esforçar } \\
\text { para que o beneficio seja provido mesmo } \\
\text { que ele sozinho tenha que arcar com todo o } \\
\text { ônus }\end{array}$ \\
\hline & & Intermediários & $\begin{array}{l}\text { Situação em que nenhum membro obtém } \\
\text { sozinho uma parte do ganho } \\
\text { suficientemente grande para incentiva-lo a } \\
\text { prover o beneficio, mas que não tem tantos } \\
\text { integrantes a ponto de um membro não } \\
\text { perceber se o outro está ou não a prover o } \\
\text { beneficio coletivo }\end{array}$ \\
\hline $\begin{array}{l}\text { Competição } \\
\text { Atomizada }\end{array}$ & $\begin{array}{l}\text { Situação em que } \\
\text { nenhuma empresa tem } \\
\text { um efeito perceptivel } \\
\text { sobre qualquer outra }\end{array}$ & Latente & $\begin{array}{l}\text { Situação em que um membro não pode, por } \\
\text { definição, fazer uma contribuição perceptivel } \\
\text { a qualquer esforço grupal e, já que ninguém } \\
\text { no grupo reagirá se ele não fizer nenhuma } \\
\text { contribuição, ele não terá incentivo para } \\
\text { contribuir }\end{array}$ \\
\hline
\end{tabular}

Fonte: Olson, 1971

A explicação de Olson, portanto, demonstra de maneira cabal que a ação coletiva é mais complexa de se obter em grupos grandes e não organizados para tal fim, o que o autor denominou como grupos latentes. Nesse sentido, a organização torna-se um fator fundamental para o sucesso da ação coletiva e o provimento do bem público, evitando o problema do carona, na teoria olsoniana. 
Há, no entanto, outro problema relacionado à ação coletiva, exposto por Garret Hardin em seu ensaio "A Tragédia dos Comuns" (1968), publicado pouco antes do livro de Olson, onde o autor se apropria de um ensaio do matemático William Forster Loyd para enunciar uma situação em que determinados recursos comuns poderiam ser esgotados por meio de ações racionais de atores buscando maximizar sua utilidade individual.

Sua argumentação se vale de uma metáfora de uma pastagem compartilhada por pastores que buscam maximizar sua produção por meio do aumento do rebanho, o que geraria um componente positivo (o lucro sobre cada animal adicional) e um negativo (a degradação da pastagem para cada animal adicional). Diante disso, é possível perceber que o ganho é individual, enquanto que o prejuízo é socializado por todos os pastores, gerando incentivos para que, racionalmente, a estratégia dominante do pastor será sempre acrescentar mais animais à pastagem.

A despeito de ser individualmente a conduta que mais obedece à racionalidade, 0 acúmulo de animais acabará pondo fim ao pasto comum e inviabilizar a criação de qualquer animal, gerando um resultado socialmente pior a todos os pastores, que perderão suas criações.

Assim, para Hardin, a metáfora da pastagem pode ser aplicada a outros recursos comuns como peixes num lago, parques nacionais e até mesmo a publicidade. Diante da inevitabilidade desta "tragédia", o autor afirma que a solução passaria necessariamente por duas medidas alternativas: uma regulação estatal mais direta, com sanções e coerção ou a privatização do recurso.

É curioso perceber que tanto o texto de Mancur Olson como o de Garret Hardin abordam a questão da ação coletiva e suas limitações, sob óticas distintas, mas complementares. O problema do carona exposto por Olson reside numa questão de externalidade positiva para aqueles que não pagaram e acabam por usufruir do bem, desestimulando a ação coletiva.

Já o problema da tragédia dos comuns de Hardin reside numa externalidade negativa relacionada à possibilidade do esgotamento de determinado bem diante de seu uso excessivo. Em ambos os casos, a racionalidade individual não se traduz em ganhos coletivos e a cooperação parece não constituir uma alternativa possível em nenhum dos casos, aproximando a problemática da ação coletiva do clássico "dilema do 
prisioneiro" 39 , onde a racionalidade individual pode conduzir a um resultado coletivamente pior a todos. Assim, como afirmam Poteete, Jansem \& Ostrom (2011), os dilemas sociais acabariam por envolver um conflito patente entre a racionalidade individual, fundada no benefício próprio de curto prazo, e a escolha dos melhores recursos disponíveis ao grupo como um todo

Diante deste problema, os trabalhos de Elinor Ostrom - notadamente Governing the Commons: The Evolution of Institutions for Collective Action de 1990, além dos posteriores - surgem criticando a teoria de ação coletiva baseada na escolha racional e trazem a possibilidade de uma via alternativa entre uma regulação estatal fechada ou uma privatização pura e simples dos recursos: o conceito de auto-regulação dos CPRs (Common Pool Resources) para "regulamentar e monitorar o uso dos bens que são de todos e, ao mesmo tempo, não pertencem a ninguém" 40 . Cabe enfatizar que, de acordo com Ostrom, tal regulamentação não obedece a uma forma única, sendo necessário compreender as características de cada grupo para que a cooperação seja, de fato, efetiva, matizando a ideia de racionalidade absoluta dos atores.

Nesse ponto, Ostrom se aproxima de autores da literatura de regulação transnacional na medida em que, como já vimos, propõem alternativas como as gerações de certificações de Nadvi e Wältring (idem), a governança híbrida de Williamson (idem) e os arranjos multistakeholder de Buthe \& Matlli (2011).

Buthe (2010), aliás, é um dos que mais se aproximam de Ostrom ao concluir que as cadeias produtivas globais apresentam conflitos distributivos que tornam a cooperação orientada pelos estados largamente inefetiva. Nesse sentido, os atores privados - subdivididos entre provedores, demandantes e alvos de regulação - estarão pautados por uma relação de custo-benefício, onde a cooperação se dará na medida em que os custos de coordenar as ações forem menores que os benefícios coletivos auferidos pelas iniciativas.

\footnotetext{
${ }^{39} \mathrm{O}$ “dilema do prisioneiro” é um problema clássico de Teoria dos Jogos onde se supõe que há dois prisioneiros incomunicáveis interrogados separadamente pela polícia e cujas opções são: negar o crime ou cooperar entregando o outro. No caso de ambos negarem, a pena seria mais branda para os dois, enquanto que se apenas um negar e o outro delatar, o que negou terá uma pena maior e o delator se verá livre da prisão. Já no caso de ambos delatarem, a pena é mais dura para os dois, embora menor que aquela aplicada a um único delatado. Diante disso, a estratégia racional seria delatar, abrandando a pena diante de uma eventual delação do companheiro. No entanto, isso levará a um resultado sub-ótimo a ambos.
}

${ }^{40}$ Poteete, Jansem \& Ostrom (idem) 
Ostrom, contudo, vai além da crítica às tradicionais teorias de ação coletiva e da defesa normativa da auto-regulação, traçando uma série de princípios para facilitar a adaptação - nos moldes de Cashore (idem) - em um processo denominado "governança adaptativa": i) buscar informação precisa e relevante, focando na produção e utilização de conhecimento científico pelos administradores e consumidores; ii) administrar os conflitos por meio de mecanismos de soluções de controvérsias pré-estabelecidos; iii) reforçar o compliance com as regras por meio da responsabilização via monitoramento; iv) prover a infra-estrutura adequada para estabelecer ligações externas e auxiliar a cooperação interna e v) encorajar a adaptação e a mudança para minorar os equívocos a cada novo desenvolvimento.

O primeiro princípio, que foca no componente da informação precisa e relevante, destaca-se nos trabalhos posteriores de Ostrom (1998) onde a autora compõe um pequeno modelo, expresso na Figura 15, para ilustrar a interação entre custos e benefícios na interação dos atores dentro dos esquemas cooperativos e destes com o mundo externo.

Figura 15 - Comunicação e informações no trabalho de Elinor Ostrom

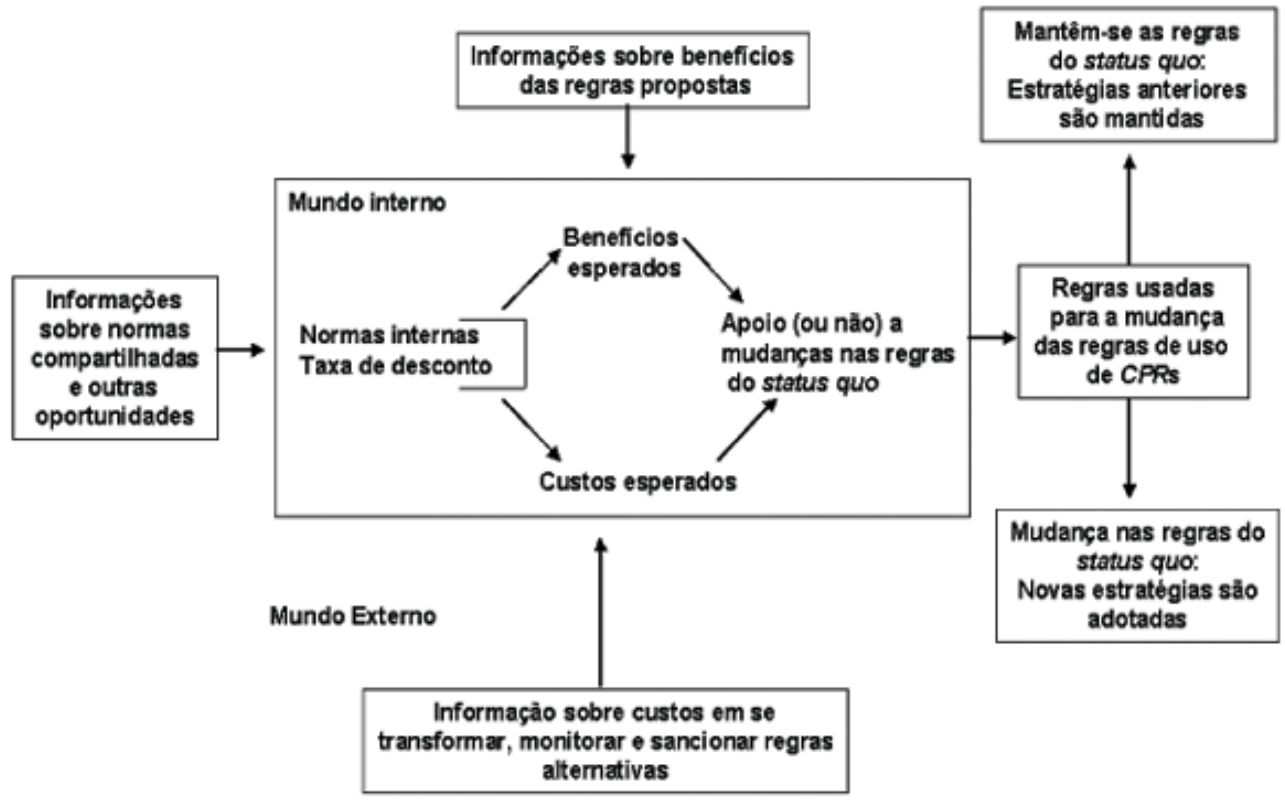

Fonte: Ostrom (1998) traduzida por Andrews (2005) 
Conforme podemos observar, a comunicação das informações é essencial para que a cooperação seja atingida, estabelecendo-se em três modalidades essenciais: sobre as normas compartilhadas entre os atores e sobre os custos e benefícios para o estabelecimento das regras. Todo esse conjunto impacta na arena onde os custos e benefícios são processados para a criação de regras que balizam a cooperação, as quais, por sua vez, estão sujeitas a mudanças ou manutenção do status quo.

Além das informações, Ostrom reforça, neste mesmo trabalho, a importância de ativos como a reputação, a confiança e a reciprocidade para que, em pequenos grupos, a cooperação possa ser alcançada. De acordo com a autora, como podemos acompanhar na Figura 16, desenvolve-se um círculo virtuoso entre estes três ativos.

Figura 16 - Reputação, Reciprocidade e Confiança para aumentar os níveis de cooperação no trabalho de Ostrom

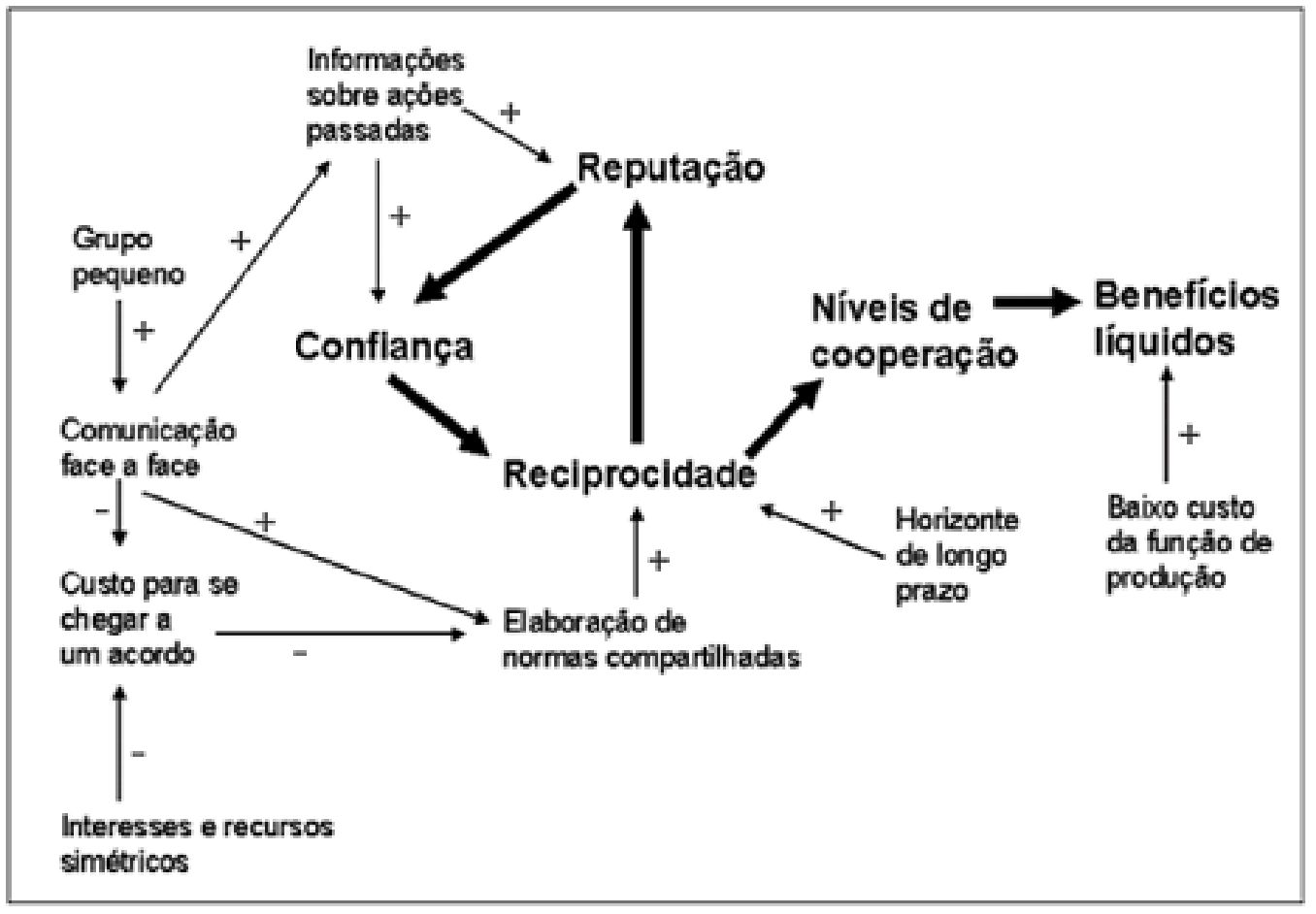

Fonte: Ostrom (1998) traduzida por Andrews (2005)

Assim, a reputação torna-se um ativo muito importante para que os atores adquiram confiança uns nos outros, sendo que esta confiança será a base da reciprocidade em determinadas ações, a qual, por sua vez, deverá consolidar a reputação 
dos atores perante os outros, resultando em uma dinâmica que favorece a criação da arena em que os atores podem estabelecer acordos de cooperação, sejam eles formais ou informais, a depender de cada caso.

Compreendidas estas variáveis, é importante ressaltar que estes dois quadros compõem a base do modelo que Ostrom viria a criar denominado Arcabouço de Análise e Desenvolvimento Institucional ${ }^{41}$, exposto na Figura 17, o qual é composto por um conjunto de variáveis exógenas influenciando a chamada "arena de ação".

\section{Figura 17 - Arcabouço de Análise e Desenvolvimento Institucional ou IAD Framework}

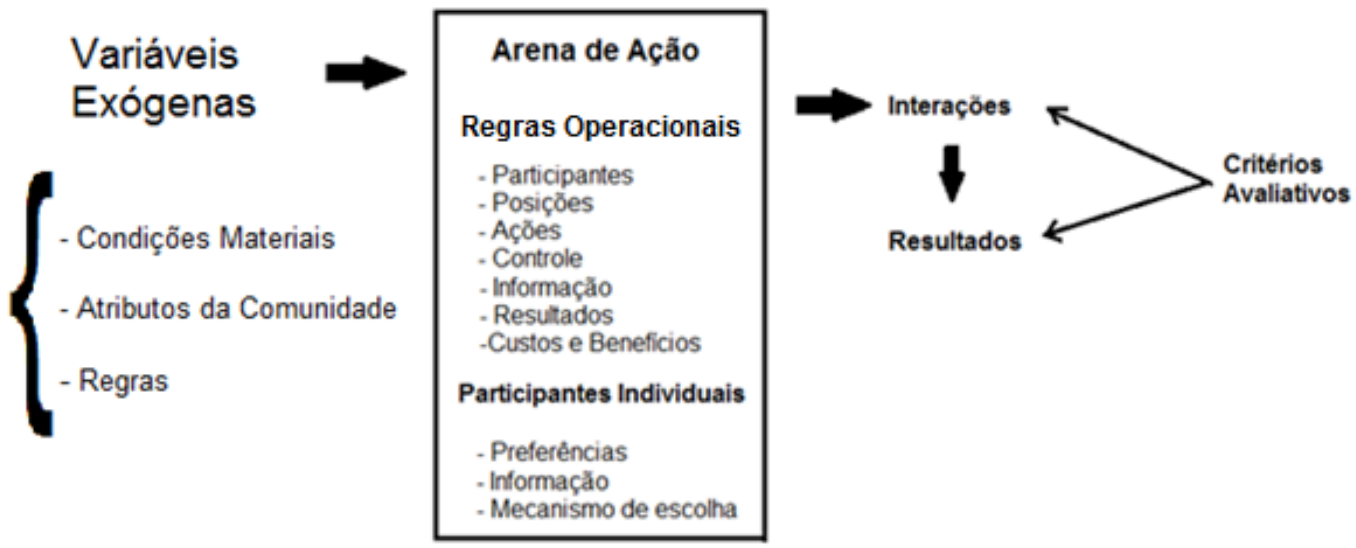

Fonte: Elaborado pelo autor a partir de Ostrom (2007)

As variáveis exógenas expostas por Ostrom seriam de três categorias: i) as condições materiais em que os atores se encontram, ii) os atributos das comunidades em que eles estão inseridos, definindo uma espécie de "cultura" própria e iii) as regras implícitas ou explícitas que balizam as relações iniciais entre os atores.

$\mathrm{Na}$ esfera da "arena de ação", influenciada por estas variáveis exógenas, interagem as regras operacionais e as preferências individuais dos atores. No caso das

\footnotetext{
${ }^{41}$ No original, em inglês, o nome do modelo é Institutional Analysis and Development framework, também chamado de IAD Framework.
} 
regras operacionais, seu conteúdo ${ }^{42}$ está ligado às premissas da própria negociação entre os atores, ou seja, quem e como participa, em que posição, com qual informação, como se agregam, sob quais limites, operando qual estrutura de pay-offs.

Com estas regras, na arena de ação de Ostrom, interagem as ações dos participantes individuais baseados em suas preferências, informações disponíveis e mecanismos de escolha, conduzindo a determinados resultados (outcomes), permanentemente sujeitos a critérios de avaliação ${ }^{43}$.

Nesse sentido, com base no diálogo no interior desta arena, os atores desenvolvem, em cada caso específico, um tipo de auto-regulação que observa, para Ostrom, alguns princípios gerais cujo conteúdo evocaria uma certa regularidade institucional, sendo eles: i) estabelecer limites claramente definidos para participação; ii) definir a congruência entre apropriação de benefícios e provisão de regras às condições locais; iii) assegurar um processo de escolha coletiva, ou seja, que os membros afetados pelas regras possam participar de sua elaboração iv) desenvolver um monitoramento constante e confiável sobre o cumprimento de regras pelos membros; v) desenhar sanções graduais aos descumpridores das regras conforme o grau de violação; vi) criar mecanismos de solução de controvérsias que exponham os conflitos entre os atores; vii) garantir o reconhecimento legal mínimo dos direitos entre todos a autoorganização e viii) construir a responsabilidade de governar o recurso em camadas aninhadas, criando um processo de interdependência entre grandes e pequenos atores.

\footnotetext{
${ }^{42}$ É importante ter em mente que estas regras operacionais não são fixas, mas podem ser alteradas por meio de negociações entre os atores chamadas de regras de escolha coletiva. Tais regras, por sua vez, também podem ser alteradas pelas chamadas regras constitucionais que definem sob quais pressupostos poderiam se dar as mudanças nas regras operacionais e nas regras de escolha coletiva, alterando critérios de elegibilidade para a participação e de governança para as operações, formatando os limites normativos da arena.

${ }^{43}$ Nesse sentido, o modelo de Ostrom guarda importante semelhança com as ideias de Fligstein (2009) para quem a ação coletiva também só ocorre calcada na cooperação dos atores que definem seus interesses e identidades coletivas por meio de um processo de habilidade cujo objetivo seria alcançar valores prioritários comuns. Tal teoria, denominada "teoria dos campos", constitui um importante marco teórico da sociologia, se aproximando do modelo neo-institucionalista de Ostrom, qualificando a interação social por características como a "habilidade".
} 
Tal modelo pode, assim, constituir o que a autora denomina "quadro de referências" com fins de analisar os problemas de escolha institucional, ilustrando as configurações de variáveis a ser consideradas nas ocasiões em que os indivíduos buscam elaborar regras para melhorar seus resultados individuais e coletivos" (Ostrom, idem). Nesse sentido, nossa última seção se destinará a aplicar as teorias de ação coletiva, inclusive este quadro, no caso das certificações socioambientais, tomando por base o BSI-Bonsucro.

4.2. As certificações como problema de ação coletiva: o BSI-Bonsucro sob a ótica de Mancur Olson e Elinor Ostrom

Ainda que os arranjos de certificação se comportem ora como um bem público , ora como um bem de clube - o primeiro para a sociedade e o segundo para os associados - é possível utilizar as teorias desenvolvidas na seção anterior para a compreensão da cooperação dos atores em torno dos arranjos de certificação multistakeholders de diversas cadeias produtivas como a soja, a palma, biocombustíveis, entre outros. Para ilustrar tal questão, buscaremos verificar tais conceitos à luz do caso que esmiuçamos no capítulo anterior: o BSI-Bonsucro.

Nesse sentido, podemos afirmar que o caso do BSI-Bonsucro evoca algumas questões importantes tanto no que concerne às teorias de ação coletiva tradicionais, capitaneadas por Olson quanto àquelas mais recentes, representadas pelo trabalho de Ostrom.

No que diz respeito à interface com os trabalhos de Olson, podemos verificar que a provisão do bem público - na forma de práticas ambientais e sociais mais sustentáveis dos membros para a sociedade - não estaria garantida diante da profusão de atores que podem se beneficiar das mesmas e não possuem qualquer incentivo para se organizar em torno desse objetivo.

Assim, esta provisão apenas ocorre porque um pequeno grupo de grandes produtores na cadeia de cana, pressionados por atores da sociedade civil e consumidores, uniram-se para promover as práticas supracitadas, as quais garantem a tais produtores a possibilidade de maior acesso a outros mercados bem como assegurar sua reputação nos mercados já atendidos. Dessa forma, concordamos com Chaddad \& 
Moura (2012), que o BSI-Bonsucro forma o que Olson denominou de grupo intermediário, onde a garantia do bem público carece de incentivos para ocorrer.

Estes incentivos podem ser de diversas naturezas devido à heterogeneidade do grupo, desde benefícios de imagem e reputacionais no caso das associações de terceiro setor até acessos a mercados exigentes, como o europeu, no caso de produtores e conglomerados da cadeia de cana.

De posse da ideia de que o BSI-Bonsucro constitui um caso de grupo intermediário que necessita de incentivos para a cooperação, vale utilizar os princípios enunciados por Ostrom para analisar se este arranjo tem aplicado a maioria deles, garantindo uma estrutura que permita a cooperação entre seus atores. Para isso, recorreremos ao trabalho de Chaddad \& Moura (2012) e ao próprio regimento da Bonsucro (2015) para elaborar o quadro 11 onde cotejamos estes com a dinâmica de ação coletiva do BSI-Bonsucro:

Quadro 11 - Princípios de governança de Ostrom no BSI-Bonsucro

\begin{tabular}{|c|c|}
\hline Princípios de governança & Aplicação no BSI-Bonsucro \\
\hline \multirow{2}{*}{ I) Limites claramente definidos } & $\begin{array}{c}\text { A filiação é aberta, mas seletiva, } \\
\text { condicionada ao pagamento de taxas e } \\
\text { observação dos critérios. Apenas os } \\
\text { membros podem participar das decisões. }\end{array}$ \\
\hline II) Congruência entre provisão de & $\begin{array}{c}\text { O processo de estabelecimento de regras é } \\
\text { transparente e participativo, seguindo o } \\
\text { código ISEAL, além de privilegiar os }\end{array}$ \\
& $\begin{array}{c}\text { aspectos locais definindo grupos de } \\
\text { trabalho em vários locais do mundo. }\end{array}$ \\
\hline III) Arranjos de escolha coletiva & $\begin{array}{c}\text { A composição variada e o processo } \\
\text { decisório que, apesar de verticalizado, } \\
\text { leva em conta as decisões de todos por } \\
\text { meio de consultas e eleições diretas com } \\
\text { todos os membros. Além disso, o } \\
\text { Conselho é composto de maneira } \\
\text { equânime e horizontal. }\end{array}$ \\
& \\
\hline
\end{tabular}




\begin{tabular}{|c|c|}
\hline IV) Monitoramento constante & $\begin{array}{c}\text { O monitoramento é realizado } \\
\text { constantemente pelos próprios } \\
\text { stakeholders e por auditores externos. }\end{array}$ \\
\hline V) Sanções graduais & $\begin{array}{c}\text { As sanções existem, mas não são graduais, } \\
\text { pois ao prejudicar o grupo, podem ser } \\
\text { expulsas imediatamente. }\end{array}$ \\
\hline VI) Mecanismos de solução de & $\begin{array}{r}\text { A resolução de controvérsias se dá por } \\
\text { terceiras partes, sendo comum a }\end{array}$ \\
controvérsias & $\begin{array}{r}\text { O arranjo é registrado como uma de técnicos para esclarecer as } \\
\text { questões litígio. }\end{array}$ \\
\hline VII) Direito de auto-organização & organização não lucrativa sob as leis da \\
& Inglaterra e País de Gales. \\
\hline VIII) Empresas aninhadas & Não se aplica \\
\hline
\end{tabular}

Fonte: elaborado pelo autor a partir de Chaddad \& Moura (2012), Ostrom (2007) e BSIBonsucro (2016)

No caso do princípio I - estabelecimento de limites claramente definidos para participação - podemos observar as regras de filiação que prevêem uma configuração aberta, ainda que selecionada pelos membros mais antigos e condicionada ao pagamento de taxas diferenciadas e cumprimento de critérios de entrada e permanência, sendo esta última o requisito para a participação no processo decisório.

Já o princípio II - definição da congruência entre apropriação de benefícios e provisão de regras às condições locais - pode ser visto na transparência de cada decisão a todos os membros, seguindo os princípios da ISEAL e privilegiando o aspecto local por meio dos Grupos Técnicos de Trabalho, estabelecidos ao redor do mundo bem como arrefecendo as taxas de participação a organizações de países em desenvolvimento.

Para o princípio III - garantia de um processo de escolha coletiva, ou seja, que os membros afetados pelas regras possam participar da elaboração das regras - podemos verificar que o arranjo é composto de diversas categorias de atores (conglomerados, produtores, terceiro setor, traders) que participam das decisões de maneira direta, seja 
em consultas públicas, seja nos processos eleitorais para escolher os membros do Conselho.

No caso dos processos eleitorais, é importante ressaltar que o voto é direto e não guarda qualquer critério censitário com relação aos participantes que, grandes ou pequenos, dispõe cada um de um voto. Ademais, os eleitos precisam representar, necessariamente, os diferentes grupos de membros de maneira equânime, evitando que um grupo se sobressaia ao outro nos rumos do arranjo.

O princípio IV - desenvolvimento de um monitoramento constante e confiável sobre o cumprimento de regras pelos membros - abarca tanto a vigilância entre os próprios pares como as auditorias externas, constantemente realizadas para evitar que os critérios não deixem de ser observados ou cobrados pelos pares de maneira seletiva.

No que diz respeito ao princípio V - o desenho de sanções graduais aos descumpridores das regras conforme o grau de violação - podemos dizer que ele é atendido parcialmente no caso da BSI-Bonsucro: o descumprimento de regras aliado a atitudes contra a iniciativa acarreta a expulsão do membro. Portanto, apesar da existência de sanções, não há qualquer gradualismo para sua implementação.

Com o princípio VI - a criação de mecanismos de solução de controvérsias que exponham os conflitos entre os atores - é possível afirmar que há um cumprimento total, na medida em que a maioria das controvérsias entre os membros é solucionada por terceiras partes, sendo estas geralmente órgãos técnicos de expertise comprovada na área do litígio em questão. O mesmo ocorre com o princípio VII - garantia de um reconhecimento legal mínimo dos direitos entre todos à auto-organização - uma vez que a iniciativa existe enquanto uma organização sem fins lucrativos, sob a égide da legislação da Inglaterra e do País de Gales.

Por fim, cabe ressaltar que o princípio VIII - a construção da responsabilidade de governar o recurso comum em camadas aninhadas, criando um processo de interdependência entre grandes e pequenos atores - não é observada por não estarmos tratando de um recurso comum clássico, nos moldes estabelecidos por Ostrom

Assim sendo, conforme pudemos observar, o BSI-Bonsucro acaba por se adequar à vasta maioria dos princípios enunciados por Ostrom, abrindo caminho para que possamos analisar a dinâmica de criação de regras no interior do arranjo por meio do modelo institucional desenvolvido pela autora.

Retomando o modelo IAD, é preciso verificar quais as variáveis exógenas que orbitam em torno do BSI-Bonsucro e como se caracterizaria a composição da "arena de 
ação". Nesse caso, diante do estudo que procedemos, podemos adotar a seguinte configuração, expressa no quadro 12:

Quadro 12 - Variáveis Exógenas ao caso BSI-Bonsucro no Modelo IAD de Ostrom

\begin{tabular}{|c|c|}
\hline Tipo de Variável Exógena & Caso BSI-Bonsucro \\
\hline Condições Materiais & $\begin{array}{c}\text { Setor sucroalcooleiro com produção } \\
\text { pulverizada da ordem de milhões de } \\
\text { toneladas de cana e de alto impacto } \\
\text { ambiental e social }\end{array}$ \\
\hline Atributos de Comunidade & $\begin{array}{c}\text { Comunidade numerosa e heterogênea com } \\
\text { atores de diversas naturezas como } \\
\text { conglomerados empresariais, membros do } \\
\text { agronegócio, traders, consumidores e } \\
\text { representantes da sociedade civil }\end{array}$ \\
& $\begin{array}{c}\text { Guia de Produção BSI-Bonsucro, } \\
\text { despontando em meio a uma série de } \\
\text { regulações estatais e privadas. }\end{array}$ \\
\hline
\end{tabular}

Fonte: elaborado pelo autor a partir do modelo de Ostrom (2007)

A primeira variável exógena, que diz respeito às condições materiais postas em torno do BSI-Bonsucro, contempla o setor sucroalcooleiro com sua produção pulverizada em milhares de produtores - e milhões de toneladas de cana produzidas cujo impacto social e ambiental tem sido bastante alto. ${ }^{44}$

No caso da segunda variável, ligada aos atributos da comunidade, podemos verificar uma comunidade bastante numerosa e heterogênea, com membros de diversas naturezas, divididos em conglomerados empresariais, membros do agronegócio, traders, consumidores e representantes da sociedade civil.

Por fim, a terceira variável, expressa pelas regras do setor, pode ser representada por uma série de iniciativas de certificações do setor sucroalcooleiro, tanto de natureza

\footnotetext{
${ }^{44}$ De acordo com o que já apontamos no quadro 7.
} 
estatal como privada ${ }^{45}$, cujo exemplo mais bem acabado é justamente o BSI-Bonsucro que desenvolvemos neste trabalho.

Tendo esmiuçado as variáveis exógenas, o passo seguinte é examinar a arena de ação, cujo conteúdo é o ponto central do modelo IAD e comporta um conjunto de regras operacionais no quadro daquilo que Ostrom denominou como "situação da ação", conforme o quadro 13 abaixo:

\section{Quadro 13 - Regras operacionais e seus efeitos no BSI-Bonsucro}

\begin{tabular}{|c|c|c|}
\hline Tipos de Regras & Efeitos das regras & Caso BSI-Bonsucro \\
\hline Regras de Participação & Critérios de entrada e saída & $\begin{array}{l}\text { A admissão e a expulsão } \\
\text { dos membros obedecem a } \\
\text { critérios pré-fixados e estão } \\
\text { sujeitos à aprovação do } \\
\text { Conselho }\end{array}$ \\
\hline Regras de Posição & Posições dos atores & $\begin{array}{l}\text { As posições são iguais com } \\
\text { a exceção da observação do } \\
\text { respeito à hierarquia do } \\
\text { Conselho, onde a } \\
\text { composição é equânime }\end{array}$ \\
\hline Regras de Escolha & $\begin{array}{c}\text { Ações possíveis a cada } \\
\text { posição }\end{array}$ & $\begin{array}{l}\text { Cada ator possui o mesmo } \\
\text { rol de ações possíveis, } \\
\text { regulados pelos critérios } \\
\text { estabelecidos }\end{array}$ \\
\hline Regras de Agregação & $\begin{array}{l}\text { Nível de controle dos } \\
\text { participantes em cada } \\
\text { situação }\end{array}$ & $\begin{array}{c}\text { O controle de cada } \\
\text { participante é feito tanto } \\
\text { pelos seus pares (horizontal } \\
\text { ou vertical pelo Conselho) } \\
\text { e por auditorias contratadas } \\
\text { de terceiras partes }\end{array}$ \\
\hline Regras de Informação & $\begin{array}{c}\text { Nível de informação } \\
\text { disponível a cada }\end{array}$ & $\begin{array}{c}\text { As informações são } \\
\text { disponíveis a todos os }\end{array}$ \\
\hline
\end{tabular}

${ }^{45}$ Conforme expresso na tabela 2. 


\begin{tabular}{|c|c|c|}
\hline & participante & $\begin{array}{c}\text { participantes por meio de } \\
\text { boletins periódicos e } \\
\text { sistema on-line. }\end{array}$ \\
\hline Regras de Payoffs & $\begin{array}{c}\text { Distribuição da relação } \\
\text { custo/benefício associada a } \\
\text { cada participante }\end{array}$ & $\begin{array}{c}\text { As taxas cobradas por cada } \\
\text { participante são } \\
\text { proporcionais à dimensão, } \\
\text { à natureza e ao país de } \\
\text { origem de cada membro }\end{array}$ \\
\hline Regras de escopo & Abrangência dos resultados & $\begin{array}{c}\text { Os seis princípios, } \\
\text { desdobrados em 28 } \\
\text { critérios e 69 indicadores } \\
\text { buscam prover melhores } \\
\text { índices socioambientais }\end{array}$ \\
\hline
\end{tabular}

Fonte: elaborado pelo autor a partir de Ostrom (2007) e BSI-Bonsucro (2016)

No campo das regras operacionais, é importante analisar os sete indicadores em que elas se desdobram. Em primeiro lugar, as regras de participação prevêem que todos os candidatos a serem admitidos como membro do BSI-Bonsucro têm acesso a um rol pré-fixado de critérios, com um mesmo modus operandi expresso na Figura 12.

Cabe ressaltar, contudo, que tanto este processo de admissão como uma eventual expulsão devem passar antes pelo Conselho, que é responsável pela palavra final nesses casos. Nesse sentido, cabe esclarecer que s regras de posição prevêem que todos os atores são horizontalmente iguais, com exceção dos membros do Conselho, que, eleitos por seus pares, possuem a prerrogativa de comandar certos processos e definições.

Já as regras de escolha determinam as possibilidades de ações de cada um dos atores da iniciativa, a qual deve obedecer aos critérios estabelecidos conforme informado no Capítulo 3 pelos seis princípios do BSI-Bonsucro. Por sua vez, as regras de agregação dizem respeito aos controles dos atores que é efetuado tanto por seus pares - horizontalmente por todos os membros e verticalmente do Conselho para os demais como por auditorias externas contratadas especificamente para este fim.

No que concerne às regras de informação, cabe esclarecer que a comunicação é bastante ampla e acessível, com boletins periódicos e todas as informações abertas virtualmente, inclusive aquelas referentes a novos membros e novos certificados. Da 
mesma forma, as regras de pay-offs determinam uma estrutura de custos/benefícios cujos critérios são amplamente conhecidos e estão ligados a taxas proporcionais à dimensão, natureza e posição socioeconômica do país de origem de cada membro.

Para encerrar, as regras de escopo determinam a abrangência dos resultados que, pautados nos seis princípios, 28 critérios e 69 indicadores, espraiam-se por todos os 487 membros e para além deles, reduzindo impactos ambientais e sociais da cadeia de canade-açúcar.

Diante deste conjunto de regras, o modelo de Ostrom informa que cada ator lastreado em nas preferências que esposa, na informação que detêm e em seu próprio mecanismo de escolha - adapta-se ou interage com elas, determinando uma série de interações. $\mathrm{Na}$ esteira de tais interações são produzidos resultados que determinam o comportamento deles na cadeia de cana-de-açúcar que podem ser tanto a criação de regras e critérios para a cadeia de cana-de-açúcar como seu conseqüente impacto neste setor, minorando os danos ambientais e sociais na cadeia de cana-de-açúcar.

Fica patente que não há um caminho único ou fácil para a criação de regras em nível transacional, mas com base nas teorias de ação coletiva apresentadas acima - e em sua interface com o caso de iniciativa de certificação multistakeholder BSI-Bonsucro - é possível perceber que alguns critérios vêm sendo seguidos e, com isso, tem se alcançado relativo sucesso na regulação de cadeias produtivas.

\subsection{Considerações Finais e agenda de pesquisa}

Este trabalho buscou apresentar as características e limitações da ação coletiva nos arranjos de certificação multistakeholder focando o caso do BSI-Bonsucro, o caso paradigmático e crucial na cadeia de cana-de-açúcar. Atualmente, a iniciativa já conta com quase 500 membros e outros em processo de entrada, além de 58 certificados expedidos, alguns dos quais ainda não possuímos informações completas para incorporar ao trabalho ${ }^{46}$.

Em nosso estudo, buscamos esmiuçar principalmente o coração da certificação, ou seja, seus princípios, critérios e indicadores que balizam a atividade de todos os

\footnotetext{
${ }^{46} \mathrm{O}$ site da iniciativa ainda não havia trazido as informações completas sobre as novas certificações quando concluímos este trabalho, permitindo apenas visualizar a atualização para os novos membros. Diante disso, preferimos referenciar os membros até 2016 e as certificações até 2015.
} 
membros, bem como os processos de adesão de novos atores e de certificação dos participantes. Além do estudo de caso pormenorizado acerca do BSI-Bonsucro e da análise deste à luz das teorias de ação coletiva, nosso trabalho também pretendeu revisar a literatura acadêmica acerca dos aspectos gerais da certificação e da cadeia internacional de cana-de-açúcar, oferecendo material para novos estudos acerca de ambos os temas, ambos candentes em várias áreas do conhecimento, em especial no estudo de novos arranjos de governança global.

Tais arranjos constituem uma nova modalidade de organização dos atores no plano internacional que, nas últimas décadas, tem sido uma importante novidade para além dos estados e das organizações intergovernamentais, colocando em uma nova perspectiva o estudo das Relações Internacionais, mormente aqueles inseridos na escola Neo-institucionalista.

Ainda é bastante complexo determinar qualquer tipo de causalidade no que diz respeito ao efeito de tais mecanismos de governança e a redução do impacto socioambiental, mas o mapeamento de tais iniciativas - destacando suas características, sua estrutura institucional e a evolução dos critérios que a compõe - pode contribuir sobremaneira para o entendimento da ação coletiva em nível transnacional.

Dessa maneira, buscamos apresentar uma contribuição acerca do comportamento de novos atores no cenário internacional, articulando a literatura de governança privada com aquela referente às teorias de ação coletiva. Enquanto a teoria de Olson trouxe a contribuição de identificar as características deste arranjo como grupo intermediário, o referencial de Ostrom buscou evidenciar as características da cooperação.

O modelo institucional de Ostrom constitui uma importante forma de interpretação das ações e regras que balizam o comportamento dos esquemas de certificação e dos atores que os integram, contemplando uma dinâmica geral e complementando a visão sobre os pontos específicos que o restante da literatura de governança privada tem iluminado. Diante desse esforço, é preciso pontuar que não pretendemos esgotar as possibilidades de tal articulação, mas sim abrir um caminho para novos estudos acerca do tema.

Uma primeira agenda de pesquisa aponta para estudos de caso mais pormenorizados, enfatizando alguns atores dentro dos esquemas de certificação, a fim de identificar seu papel e sua contribuição, além do impacto de sua participação na referida iniciativa. Nossa opção foi por promover um estudo mais geral sobre os arranjos de certificação, mas compreender como um grande conglomerado industrial ou 
um pequeno produtor se comportam nesta interação pode ser fundamental para compreendermos melhor os esquemas de certificação e como eles influenciam aqueles que decidem participar deles.

Outra possibilidade é realizar estudos mais acurados de compliance que, amparados em teorias de escolha racional, permitem verificar o grau de comprometimento dos atores com as determinadas iniciativas de governança que buscam integrar. Além disso, também é possível replicar este estudo para outras cadeias produtivas, sejam agrícolas, sejam de produtos manufaturados, as quais cada vez mais tem se organizado em arranjos transnacionais, a fim de defender seus interesses, acessar mercados e diminuir o impacto de seus processos produtivos.

Por fim, a atualização deste trabalho, dado o constante crescimento da cadeia de cana e do próprio BSI-Bonsucro, também seria uma importante contribuição, a fim de que os números, procedimentos - e, por consequiência, a própria análise, não acabem perdidas no anacronismo que condena os trabalhos pouco visitados.

Se esta tese contribuir minimamente para uma melhor compreensão dos novos fenômenos e puder trazer um pequeno subsídio a futuros trabalhos de Relações Internacionais e Ciência Política, consideramos a missão deste trabalho plenamente cumprida em seu objetivo primordial: contribuir com a ciência e sua perpetuação. 


\section{REFERÊNCIAS}

ABDALA, F. Governança global sobre florestas - O caso do programa piloto para proteção das florestas tropicais - PPG7 (1992-2006). Instituto de Relações Internacionais da Universidade de Brasília. 2007.

ABBOT, K. \& SNIDAL, D. "The Governance Triangle: Regulatory Standards Institutions and the Shadow of the State." In The Politics of Global Regulation, edited by Walter Mattli and Ngaire Woods. Princeton: Princeton University Press, 2009

AGNEW, J. "The territorial trap: the geographical assumptions of international relations theory" In Review of International Political Economy Vol.1. 1994.

AIE - Agência Internacional de Energia - World Energy Outlook 2012 - Disponível em http://www.worldenergyoutlook.org/ Último acesso em 12/12/2014.

- Dossiê Terra 2009. Disponível em http://www.eia.gov/Último acesso em 23/02/2015.

ANDREWS, C. Implicações teóricas do novo institucionalismo: uma abordagem Habermasiana in Dados 48. São Paulo. 2005.

AVANT, D., FINNEMORE, M. , e SELL, S. Who governs the globe? Cambridge. 2010.

BANANA, A. \& WILLIAM, G.S., Successful forest management: The importance of security of tenure and rule enforcement in Ugandan forests. In People and forests: Communities, institutions, and governance, eds. Clark Gibson, Margaret A. McKean, and Elinor Ostrom, eds., pp. 87-98. Cambridge, MA: MIT Press. 2000.

BARTLEY, T. 'Institutional Emergence in an Era of Globalization: The Rise of Transnational Private Regulation of Labor and Environmental Conditions', American Journal of Sociology, 113 (2), 297-351. 2007.

BERKES, F. "Fishermen and the "Tragedy of the Commons"."'In Enviromental Conservation (12). 1985. 
BERNSTEIN, S. and CASHORE, B. Can non-state global governance be legitimate? An analytical framework, Regulation \& Governance, 1(4), pp. 1-25. 2007

BNDES/CGEE - Banco Nacional Desenvolvimento Econômico e Social - Etanol de Cana-de-açúcar - Energia para o Desenvolvimento Sustentável. 2008.

BORZEL, T. \& RISSE, T. “Governance without state: Can it work?” In: Regulation and Governance 4(2). 2010.

BRADY, H. E., COLLIER, D. \& SEAWRIGHT, J. "Toward a Pluralistic Vision of Methodology", Political Analysis, vol. 14, nº 3, 2006.

BRUSZT, L \& MCDERMOTT, G “Assembling level playing fields transnational regulatory integration and institutional changing in emerging markets" in Governance of transnational regulatory integration and development. 2012.

BSI-BONSUCRO - http://www.bonsucro.com/ . Último acesso em 24/9/2016. - Guia para o Padrão de Produção Bonsucro 2015.

BUCHANAM, J. “An economic theory of clubs" In Economica New Series. Vol 32. 1965.

BUTHE, T. Special Issue: Private Regulation in the Global Economy (October 28, 2010). Business and Politics, Vol. 12, No. 3, October 2010.

BUTHE, T \& MATTLI, W. New Global Rulers: The Privatization of Regulation in the World Economy Princeton: Princeton University Press, 2011.

CASELLA, A. "On standards and trade: a review of simples results" In Bhagwati, Jagdish; Hudec, Robert (orgs.). Fair trade and harmonization. Massachusetts. MIT. 1996.

, "Product standards and international trade. Harmonization through Private Coalitions?" in KYKLOS (54). 2001.

CASHORE, B. "Legitimacy and the Privatization of Environmental Governance: How Non-State Market-Driven (NSMD) Governance Systems Gain Rule-Making Authority.” Governance 15 (4). 2002. 
CHADDAD, F e MOURA, P. "Collective action and the governance of multistakeholder initiatives: a case study of Bonsucro". In Journal on Chain and Network Science. 2012.

CHATRE, A. \& AGRAWAL, A. "Forest Commons and Local Enforcement." Proceedings of the National Academy of Sciences, 105(36): 13286-91. 2008.

COASE, R. The Nature of the Firm.. Economica, New Series, Vol. 4, No. 16. pp. 386405. 1936.

CONCEIÇÃO, J. \& BARROS, A. Certificação e rastreabilidade no agronegócio: instrumentos cada vez mais necessários - Texto para discussão, $\mathrm{n}^{\circ} 1122$. Instituto de Pesquisa Econômica Aplicada. 2005.

CONROY, Michael E. Branded! How the Certification Revolution is Transforming Global Corporations. Canada: New Society Publishers, 2007.

CONSENTINO, L. Interesses organizados na cena internacional: o lobby do etanol. Dissertação de Mestrado - Departamento de Ciência Política. FFLCH/USP. São Paulo. 2011.

CORDELL, J. \& McKEAN, M. "Sea Tenure in Bahia, Brazil". In Proceedings of the Conference on Common Property Resource Management, Annapolis Maryland, April 21-26. Ed. National Research Council. Washington, D.C.: National Academy Press. 1985

CUTLER, C. "Private international regimes and interfirm cooperation" in Rodney Bruce Hall e Thomas J. Biersteker (orgs.) The Emergence of Private Authority in Global Governance. Cambridge University Press. 2002.

DARNAL, N. \& SIDES, S. Assessing the Performance of Voluntary Environmental Programs: Does Certification Matter?. In: The Policy Studies Journal. vol. 36, n. 1, 2008 .

DEPEC - Bradesco - Departamento de Pesquisa Econômica do Banco Bradesco http://www.economiaemdia.com.br/vgn-exttemplating/v/index.jsp?vgnextoid=29fece2f8d741310VgnVCM100000882810acRCRD Último acesso em 01/01/2016. 
DESPLECHIN, E. Certificação do etanol: a visão da indústria brasileira de cana-deaçúcar. Sugar $\quad$ Industry. 2010. Disponível em http://www.unica.com.br/opiniao/show.asp?msgCode=\{3CBA204B-8951-446B-8168EB58391CD6E3\} . Último acesso em 20/02/2014.

DONADELLI, F. Motivações e resultados da certificação florestal: um estudo de caso cadeia de valor da Candeia. Ambiente \& Sociedade, São Paulo, v. 15, n. 3, p. 97-121, set./dez. 2012.

DOWNS, George; ROCKE, David; BARSOOM, Peter. Is the Good News About Compliance Good News About Cooperation? International Organization. vol. 50, $\mathrm{n}^{\mathrm{o}} 3$, summer 1996.

DYBVIG, P.\& SPATT, C. “Adoption externalities as public goods" in Journal of Public Economics (20) 1983.

EPA - Enviromental Protection Agency(Agência de Proteção Ambiental). documentos e publicações http://www.epa.gov/ Último acesso em 26/03/2015.

FAO - Organização das Nações Unidas para a Agricultura e Alimentação http://www.fao.org/home/en/ Último acesso em 30/11/2016

FARREL, J. \& SALONER, G. "Standardization, compatibility and innovation" In Rand Journal of Economics (16) 1985.

FERREIRA, G. T. C. Competitividade da cadeia produtiva do Arapaima gigas, o pirarucu da Amazônia brasileira. . Tese de Doutorado em Administração - Faculdade de Economia, Administração e Contabilidade. Universidade de São Paulo. São Paulo. 2016.

FLIGSTEIN, N. "Markets as Politics: A Political-Cultural Approach to Market Institutions.” American Sociological Review 61:656-73. 1996.

The Architecture of Markets: An Economic Sociology of TwentyFirstCentury Capitalist Societies. Princeton, NJ: Princeton University Press. 2002. 
Habilidade social e a teoria dos campos. In: Martes, Ana Cristina. Braga (org). Redes e Sociologia Econômica. São Carlos: EdUFSCar, 2009.

FOSTER, B, WANG, D \& KEETON, W. An exploratory, post-harvest comparison of ecological and economic characteristics of Forest Stewardship Council certified and uncertified northern hardwood stands. Journal of Sustainable Forestry 26(3):171-191. 2008

FORTIN, E. \& RICHARDSON, B. Certification schemes and the governance of land : enforcing standards or enabling scrutiny? Globalizations, Vol.10 (No.1). pp. 141-159. 2013.

FORTMANN, L. \& ROE, E. Common Property Management of Water in Botswana in Panel on Common Property Resource Management, Board on Science and Technology for International Development, National Research Council (eds). Proceedings of the Conference on Common Property Resource Management Washington, D.C.: National Academy Press: 161-180. 1985.

FRANSEN, L. Why Do Private Governance Organizations Not Converge? A PoliticalInstitutional Analysis of Transnational Labor Standards Regulation In Governance Vol. 24. 2011.

GEORGE, A. L. \& BENETTI, A. (2005) Case Studies and Theory Development in the Social Sciences, Cambridge, MA: MIT Press

GEREFFI, G. MAYER, F. Globalization and the Demand for Governance. In: GEREFFI, Gary. New Offshoring of Jobs and Global Development. International Labour Organization, Jamaica, 2005 ,"Regulation and Economic Globalization: Prospectsand Limits of Private Governance," Business and Politics: Vol. 12 : Iss. 3, Article 11. 2010

GERRING, J. “Case Study Research: Principles and Practices”. Cambridge: Cambridge University Press. 2007. 
GHATE, R.\& NAGENDRA, H. "Role of Monitoring in Institutional Performance: Forest Management in Maharashtra, India “ In Conservation and Society. Vol 3.2005

GLASBERGEN, P. Global action networks: agents for collective action. Global Environ Change. 2010.

GONÇALVES, R. A Captura Regulatória: Uma Abordagem Introdutória. Coimbra: Cedipre, 2014.

GREWAL, D. "Network power: the social dynamics of globalization". Yale University Press. 2008.

HALE, T. \& HELD, D. Handbook of transnational governance. Polity Press. London. 2011.

HALL, B. \& BIERSTEKER,T. The Emergence of Private Authority in Global Governance. Cambridge University Press. 2002.

HAAS, P. Introduction: epistemic communities and international policy coordination. International Organization, 46, pp 1-35. 1992

HARDIN, G. A tragédia dos comuns in Science vol 162.n.3859. 1968. Disponível em http://www.academia.edu/9163470/A_TRAG\%C3\%89DIA_DOS_COMUNS_por_Garr ett_Hardin . Último acesso 20/01/2016.

HATANAKA, M. \& BUSCH, L. Third-party certification in the global agrifood system: An objective or socially mediated governance mechanism? Sociologia Ruralis, 48, 7391. 2008.

HAUFLER,V. "New forms of governance: certification regimes as social regulations of the global market" In Errol, M., Elliot, C. \& Oesten, G. "Social and Political dimensions of Forest Certification”. 2003

HELD, D. Globalization, corporate practice and cosmopolitan social standards. Contemporary Political Theory, 1. 2002.

HERNEWAY, D. Industrywide voluntary product standards, Cambridge. Ballinger. 1975 
HOFFMAN, Andrew J. From Heresy to Dogma: An Institutional History of Corporate Environmentalism. Stanford: Stanford University Press, 2001.

HOMMEL, T. Voluntary approaches: between public justification and efficiency quest, In Workshop on Civil Sociey. Universidade de São Paulo. 2010.

KAPHENGST et alli. At a tipping point? How the debate on biofuel standards sparks innovative ideas for the general future of standardization and certification schemes. 2009.

KATZ, M. \& SHAPIRO, C. "Networks externalities, competition and compatibility" In American Economical Review (75). 1985.

KEOHANE, R. After hegemony: Cooperation and discord in the world political economy. Princeton: Princeton University Press.1984.

KING, A. \& LENOX, M. "Industry Self-Regulation Without Sanctions: The Chemical Industry's Responsible Care Program." In The Academy of Management Journal, Vol.43, No. 4. 2000.

KING G., KEOHANE, R. \& VERBA, S. “The Science in Social Science.” Designing Social Inquiry: Scientific Inference in Qualitative Research. Princeton, N.J.: Princeton University Press. 1994.

KING, A \& TERLAAK, A., "The Effect of Certification with the ISO 9000 Quality Management Standard: A Signaling Approach”., Journal of Economic Behavior and Organization, Volume 60, Number 4, pp 579-602. 2006.

KRAWIEC, Kimberly D. Cosmetic compliance and the failure of negotiated governance. In: Washington University Law Quarterly. v. 81. 2003.

\& NYE, J. Power and interdependence. Boston. Little Brown. 1997.

LADU, L. Análise Política, Econômica e Ambiental da Nova Política Energética Europeia: um enfoque sobre a indústria brasileira de bioetanol.UFBA. Salvador. 2009. 
LAM, W. Governing Irrigation Systems in Nepal: Institutions, Infrastructure and Collective Action. ICS Press, CA, Oakland. 1998.

LEVANDOWSKI, I., FAAJI, A. Steps towards the development of a certification system for sustainable bio-energy trade. Biomass and Bioenergy, 30 (2): 83-104. 2006.

LIBONI, L. B. Perfil da mão-de-obra no setor sucroalcooleiro: tendências e perspectivas. Tese de Doutorado em Administração - Faculdade de Economia, Administração e Contabilidade. Universidade de São Paulo. São Paulo. 2009.

LIEBERMAN,R. Ideas, Institutions, and Political Order: Explaining Political Change.” American Political Science Review 96: 697-712. 2002.

LIMA, V. A Avaliação de Impacto Regulatório e sua aplicação no Brasil. Rio de Janeiro. 2010.

LIPSCHUTZ, R.\& FOGEL,C. "The emergence of private authority in global governance" In Rodney Bruce Hall \& Thomas J. Biersteker (eds.), The Emergence of Private Authority in Global Governance. Cambridge University Press. 2002.

LODGE, M; WEGRICH, K. O enraizamento da regulação de qualidade: fazer as perguntas difíceis é a resposta. In: PROENÇA, J.; COSTA, P; MONTAGNER, P. Desafios da regulação no Brasil. Brasília: ENAP, 2009.

MALLET, P. \& SMITH, M. ISEAL emerging initiatives, Module 4: Models of Governance. Disponível em http://www.isealalliance.org/resources. 2007.

MARCOVITCH, J. (Org.) Certificação e sustentabilidade ambiental: uma análise crítica. São Paulo. 2012.

MARGOLIS, D. \& WALSH, J. People and profits: The search for a link between a company's social and financial performance. Lawrence Erlbaum, Mahweh, NJ. 2001 
MATTLI \& WOODS. The politics of global regulation. Princeton, NJ: Princeton University Press. 2009

NADVI, K. \& WALTRING, F. "Making Sense of Global Standards." In Local Enterprises in the Global Economy: Issues of Governance and Upgrading, edited by Hubert Schmitz, 53-94. Cheltenham: Edward Elgar. 2004

NAKAGAWA, L. A arquitetura da governance privada e a dinâmica das roundtable globais sobre a produção de insumos para biocombustíveis. UFABC. Santo André. 2013.

NAPPO, M. Certificação socioambiental: benefício ou obstáculo? Revista de $\begin{array}{lllll}\text { Agronegócio } & \text { da } & \text { Fundação } & \text { Getúlio } & \text { Vargas. }\end{array}$

Disponível em http://www.unica.com.br/opiniao/show.asp?msgCode $=\{9951 B A 72-$ B6DA-4AAB-8D53-26171A8A39C9\} Último acesso em 08/03/2015.

NASS, L. L.; PEREIRA, P. Biofuels in Brazil: An Overview. In Crop Science Review Vol. 47, 2007

NASSAR, A. M. Certificação no agribusiness. In: ZYLBERSZTAJN, D.; SCARE, R. F. (org.). Gestão da Qualidade no Agribusiness. São Paulo: Atlas, 2003. 273 p.

NASSAR, A. M. Certificação no agronegócio. Seminário Internacional PENSA de Agribusiness, 9. 1999. Anais... Águas de São Pedro: PENSA, 1999

NEVES, M. et alli . A estratégia para a cana no Brasil. Ed. Atlas. São Paulo. 2010.

NEVES, M \& ZYLBERSZTAJN, D. (orgs) Economia e gestão dos negócios agroalimentares. Pioneira. São Paulo. 2000.

NORTH, D. Institutions, Institutional Change and Economic Performance, Cambridge: Press Syndicate of the University of Cambridge. 1990. 
OLIVÉRIO, J. ; Fabricação nacional de equipamentos para a produção de álcool e cogeração; Seminário BNDES , Álcool: potencial gerador de divisas e empregos, Rio de Janeiro, 2003

OLSON, M,. The logic of collective action: public goods and the theory of groups. Harvard University Press, Boston, MA, USA.1971.

OSTROM, E., Governing the commons: The evolution of institutions for collective action. New York. Cambridge University Press. 1990.

, "A Behavioral Approach to the Rational Choice Theory of Collective Action". American Political Sciences Review, vol. 92, nº 1, pp. 1-22. 1998.

- Collective Action and the Evolution of Social Norms, The Journal of Economic Perspectives, Vo. 14, No.3, Summer, 137-158 (pgs. 141-158). 2000.

Developing a method for analyzing institutional change, workshop in Political Theory and Political Analyses, Indiana University, 2007.

OYE, K. Explaining cooperation under anarchy: Hypotheses and strategies. In Cooperation under Anarchy, ed. Oye, Princeton: Princeton University Press. 1986.

PACINI, H. \& ASSUNÇÃO, L. Sustainable biofuels in the EU: the costs of certification and impacts on new producers. Biofuels vol. 2, Issue 6. pp 595-598. 2011.

PATTBERG, P. "Private Enviromental Governance and the Sustainability Transition, Functions and Impact of NGO - Bussiness Partnerships" in KLAUS, BINDER \& WIECZOREK - Governance for Industrial Transformation. Berlin. 2004.

. The influence of global business regulation: beyond good corporate conduct in Business and Society Review 111. 2006.

PEIXOTO, G. Análise da estrutura e padrão de concorrência do setor sucroalcooleiro no Brasil. 2010.

PEROSA, B. A emergência da certificação socioambiental no mercado internacional de biocombustíveis. FGV-SP. São Paulo. 2012. 
POTEETE, A, JANSSEN, M \& OSTROM, E. Working together: collective action, the commons and multiple methods in practice. Princeton. 2011.

POTOSKI, M. \& PRAKASH, A. “Green Clubs and Voluntary Governance: ISO 14001 and Firms' Regulatory Compliance." American Journal of Political Science 49(2):23548. 2005.

RAMETSTEINER, E \& SIMULA, M. Forest certification - an instrument to promote sustainable forest management? In Journal of Enviromental Management (67). 2003.

REIN, P.. The development of sustainability standards in the sugar industry. Disponível em: http://www.bettersugarcane.org/thought_leadership.html 2009.

RODRIGUES, A. Etanol: Aspectos Jurídicos, Econômicos e Internacionais. Ed. Synergia. São Paulo, 2011

RODRIGUES, L. A cana-de-açúcar como matéria-prima para a produção de biocombustíveis: impactos ambientais e o zoneamento agroecológico como ferramenta para mitigação. UFJF. 2010.

RODRIGUES, P. Governança e regulação transnacional privada: os limites do sistema agroindustrial da soja. USP.2013.

SAMUELSON, P. The pure theory of public expenditure. 387-389 - JSTOR. 1954.

SANTOS, G. M. Estudo dos fatores envolvidos no processo de localização de usinas e destilaria: um estudo de caso do setor sucroalcooleiro brasileiro. Tese de Doutorado em Administração - Faculdade de Economia, Administração e Contabilidade. Universidade de São Paulo. São Paulo. 2014.

SCHEPERS, Donald H. Challenges to Legitimacy at the Forest Stewardship Council. In: Journal of Business Ethics. v. 92. 2009.

SHORT, J. \& TOFFEL, M. Making self-regulation more than merely symbolic: the critical role of the legal environment. 2010.

SILVA, L. Sustentabilidade do etanol brasileiro: uma proposta de princípios e critérios. UFRJ. 2010. 
SILVA-CASTAÑEDA, L. A forest of evidence: third-party certification and multiple forms of proof - a case study of oil palm plantations in Indonesia, Agriculture and Human Values, 29(3), pp. 361-370. 2012.

STIGLER, G. The teory of regulation. Chicago University. 1971.

UNICA - União da Indústria da Cana de Açúcar - http://www.unica.com.br/ . Último acesso em 12/09/2016.

USDA - United States Departament of Agriculture https://www.usda.gov/wps/portal/usda/usdahome Último acesso em 12/09/2016.

VAN DAM \& JUGINGER - Overview of recent developments in sustainable biomass certification. Biomass and Bioenergy 32(8): 749-780, 2008.

VEIGA, J. P. C. ; RODRIGUES, P. C. S. . Certificação Social e Ambiental: Arranjos Institucionais e Impactos sobre as Commodities Brasileiras. CINDES/ LATN/ FLACSO, 2010

VOGEL, D. "The private regulation of global corporate conduct". In: Mattli, W.; Woods, N. (eds.), The politics of global regulation. Princeton, NJ: Princeton University Press. 2009.

WADE, R. "The market for public office: Why the Indian state is not better at development”. World Development 13(4) 1985.

WILLIAMSON, O. Comparative economic organization: the analysis of discrete structural alternatives. In: MECHANISMS of governance. Oxford University Press, 1996.

ZEZZA, A. "Sustainability Certification in the Biofuel Sector". Harvard Kennedy School. Cambridge 2013. 
ANEXO 1 - Lista de membros do BSI BONSUCRO (2016)

\begin{tabular}{|c|c|c|}
\hline $\begin{array}{l}\text { País de } \\
\text { Origem }\end{array}$ & Membro & Setor \\
\hline África do Sul & Da Fazenda Donovale & Agronegócio \\
\hline África do Sul & Schulz Estates & Agronegócio \\
\hline África do Sul & TSB Sugar RSA (Pty) Ltd & Indústria \\
\hline Argélia & Cevital Spa & Trader \\
\hline Argentina & ARCOR SAIC - Ingenio La Providencia & Indústria \\
\hline Austrália & Australian Cane Farmers Association (CCPA) & Soc Civil \\
\hline Austrália & Bacias hidrográficas do recife & Soc Civil \\
\hline Austrália & Bundaberg Sugar Ltd & Indústria \\
\hline Austrália & Coles & Consumidor \\
\hline Austrália & G \& H Lerch Family Trust & Agronegócio \\
\hline Austrália & J. G Buchbach & Agronegócio \\
\hline Austrália & $\begin{array}{l}\text { Nova Gales do Sul Cooperativa de usinas de } \\
\text { açúcar }\end{array}$ & Indústria \\
\hline Austrália & P \& F Deguara Family Trust & Agronegócio \\
\hline Austrália & $\begin{array}{l}\text { Plantadores de Cana australianos Organização } \\
\text { Ltda }\end{array}$ & Soc Civil \\
\hline Austrália & Puglisi Farming & Agronegócio \\
\hline Austrália & R Quirk & Agronegócio \\
\hline Austrália & RJ \& AM Sluggett & Agronegócio \\
\hline Austrália & Wilmar Sugar Australia Ltd. & Indústria \\
\hline Austrália & Woolworths Limited & Consumidor \\
\hline Áustria & AGRANA Zucker GmbH & Trader \\
\hline Bolívia & Agroindustrial União De cañeros UNAGRO S.A. & Indústria \\
\hline
\end{tabular}




\begin{tabular}{|c|c|c|}
\hline Bolívia & Aliança União Associação CAA \pm eros Guabira & Soc Civil \\
\hline Bolívia & Ingenio Azucarero Guabira S.A. & Indústria \\
\hline $\begin{array}{c}\text { Bósnia e } \\
\text { Herzegovina }\end{array}$ & Studen Agrana Sugar Refinery & Indústria \\
\hline Brasil & $\begin{array}{c}\text { AAPA - Associação Ambientalista dos Pescadores } \\
\text { do Alto São Francisco }\end{array}$ & Soc Civil \\
\hline Brasil & Adecoagro - Angélica Agroenergia Ltd. & Indústria \\
\hline Brasil & Alta Mogiana AS & Indústria \\
\hline Brasil & Amaral do Site & Agronegócio \\
\hline Brasil & $\begin{array}{c}\text { André Romero Gimenes (Antiga Fazenda } \\
\text { Iguatemy) }\end{array}$ & Agronegócio \\
\hline Brasil & Anicuns S.A. Alcool e derivados (Grupo Farias) & Indústria \\
\hline Brasil & $\begin{array}{c}\text { Assobari: Associação Dos Fornecedores De Cana } \\
\text { Da Região De Bariri }\end{array}$ & Agronegócio \\
\hline Brasil & $\begin{array}{l}\text { Associação dos Fornecedores de Cana de Guariba- } \\
\text { Socicana - Alvorada }\end{array}$ & Agronegócio \\
\hline Brasil & $\begin{array}{l}\text { Associação dos Fornecedores de Cana de Guariba- } \\
\text { Socicana - MA1 }\end{array}$ & Agronegócio \\
\hline Brasil & $\begin{array}{c}\text { Associação dos Fornecedores de Cana de Guariba- } \\
\text { Socicana - Tijuco }\end{array}$ & Agronegócio \\
\hline Brasil & $\begin{array}{l}\text { Associação dos Fornecedores de Cana de Guariba- } \\
\text { Socicana - SM1 }\end{array}$ & Agronegócio \\
\hline Brasil & $\begin{array}{c}\text { Associação dos Fornecedores de Cana de Guariba- } \\
\text { Socicana - SM2 }\end{array}$ & Agronegócio \\
\hline Brasil & $\begin{array}{l}\text { Associação dos Fornecedores de Cana de Guariba- } \\
\text { Socicana - São Paulo }\end{array}$ & Agronegócio \\
\hline Brasil & $\begin{array}{l}\text { Associação dos Fornecedores de Cana de Guariba- } \\
\text { Socicana - Santana }\end{array}$ & Agronegócio \\
\hline Brasil & $\begin{array}{c}\text { Associação dos Fornecedores de Cana de Guariba- } \\
\text { Socicana - SR Boa vista }\end{array}$ & Agronegócio \\
\hline
\end{tabular}




\begin{tabular}{|c|c|c|}
\hline Brasil & BASF AS & Trader \\
\hline Brasil & BRASKEM & Trader \\
\hline Brasil & Camila Site & Agronegócio \\
\hline Brasil & Chacara Nossa Senhora Aparecida & Agronegócio \\
\hline Brasil & Chacara Pedregulho & Agronegócio \\
\hline Brasil & Chácara Webmaster & Agronegócio \\
\hline Brasil & Ciência Bayer Crop Ag & Trader \\
\hline Brasil & Condominio Arnaldo Geraldes Morelli e Outros & Agronegócio \\
\hline Brasil & $\begin{array}{l}\text { Cooperativa de Produtores de Cana-de-açucar, } \\
\text { Açucar e Alcool do Estado de São Paulo } \\
\text { (Copersucar) }\end{array}$ & Trader \\
\hline Brasil & Cosan Biomassa S/A & Trader \\
\hline Brasil & Cross Site Preta & Agronegócio \\
\hline Brasil & Della Coletta Bioenergia S / A & Indústria \\
\hline Brasil & Delson Luiz Palace (4 Fazendas) & Agronegócio \\
\hline Brasil & $\begin{array}{c}\text { Açucareira Quatá S.A, Usina Barra Grande De } \\
\text { Lençois S.A., Usina Sao Jose - Açucareira Zillo } \\
\text { Lorenzetti S.A }\end{array}$ & Indústria \\
\hline Brasil & Estância Bodoquena & Agronegócio \\
\hline Brasil & Estância Toninho & Agronegócio \\
\hline Brasil & Fazenda Santa Elena III & Agronegócio \\
\hline Brasil & Fazenda Bela Vista & Agronegócio \\
\hline Brasil & Fazenda Bela Vista II & Agronegócio \\
\hline Brasil & Fazenda Boa Vista & Agronegócio \\
\hline Brasil & Fazenda Campo Verde & Agronegócio \\
\hline Brasil & Fazenda Lajeado & Agronegócio \\
\hline Brasil & Fazenda Morumbi & Agronegócio \\
\hline Brasil & Fazenda Paraíso & Agronegócio \\
\hline
\end{tabular}




\begin{tabular}{|c|c|c|}
\hline Brasil & Fazenda Ribeirão Bonito & Agronegócio \\
\hline Brasil & Fazenda Santa Helena & Agronegócio \\
\hline Brasil & Fazenda Santa Helena II & Agronegócio \\
\hline Brasil & Fazenda Santa Izabel & Agronegócio \\
\hline Brasil & Fazenda Santa Maria & Agronegócio \\
\hline Brasil & Fazenda Santa Maria (Bonsucesso) & Agronegócio \\
\hline Brasil & Fazenda São Francisco & Agronegócio \\
\hline Brasil & Fazenda São João do Taquaral & Agronegócio \\
\hline Brasil & Fazenda São Sebastião & Agronegócio \\
\hline Brasil & Fazenda São Sebastião (Queixada 2) & Agronegócio \\
\hline Brasil & Fazenda Sítio Monte Alegre & Agronegócio \\
\hline Brasil & Fazendas Bartira & Agronegócio \\
\hline Brasil & FMC Corporation (FMC Agrícola Brasil ) & Trader \\
\hline Brasil & Fundação Espaço ECO & Soc Civil \\
\hline Brasil & $\begin{array}{l}\text { GLENCANE BIOENERGIA S/A - Unidade Rio } \\
\text { Vermelho. }\end{array}$ & Indústria \\
\hline Brasil & Grupo Bunge- Brasil & Indústria \\
\hline Brasil & Grupo Sao Martinho S. A. & Indústria \\
\hline Brasil & Grupo USJ Açúcar E Alcool S.A. & Indústria \\
\hline Brasil & Guarani S.A. & Indústria \\
\hline Brasil & LDC Bioenergia S.A. & Indústria \\
\hline Brasil & Local 2 Irmãos & Agronegócio \\
\hline Brasil & Maria Elisa Site & Agronegócio \\
\hline Brasil & Nardini Agroindustrial Ltda & Indústria \\
\hline Brasil & Noble Brasil AS & Indústria \\
\hline Brasil & O Sitio Santo Antonio (Palmital) & Agronegócio \\
\hline
\end{tabular}




\begin{tabular}{|c|c|c|}
\hline Brasil & Odebrecht Agroindustrial & Indústria \\
\hline Brasil & Pau D'Alho Sitio & Agronegócio \\
\hline Brasil & Raizen & Indústria \\
\hline Brasil & S/A Usina Coruripe Áçúcar E Álcool & Indústria \\
\hline Brasil & Sina São Luiz (Copersucar) & Indústria \\
\hline Brasil & Site Figueira & Agronegócio \\
\hline Brasil & Site pôr do sol & Agronegócio \\
\hline Brasil & Site Terra Viva & Agronegócio \\
\hline Brasil & Sitio Bananal & Agronegócio \\
\hline Brasil & Sitio CAPIM Up & Agronegócio \\
\hline Brasil & Sitio de Santa Helena & Agronegócio \\
\hline Brasil & Sitio de Santa Helena II & Agronegócio \\
\hline Brasil & Sitio Irmãos Azevedo & Agronegócio \\
\hline Brasil & Sitio Irmãos Azevedo (Ribeirão Bonito) & Agronegócio \\
\hline Brasil & Sitio Nossa Senhora Aparecida & Agronegócio \\
\hline Brasil & Sitio Nossa Senhora Aparecida (Dos Alves) & Agronegócio \\
\hline Brasil & Sitio Pedregulho I & Agronegócio \\
\hline Brasil & Sitio Santa Ana & Agronegócio \\
\hline Brasil & Sitio Santa Joana & Agronegócio \\
\hline Brasil & Sitio Santa Joana II & Agronegócio \\
\hline Brasil & Sitio Santa Rita De Cassia & Agronegócio \\
\hline Brasil & Sitio Shangri-Lá & Agronegócio \\
\hline Brasil & Sitio São João Do Coqueirinho & Agronegócio \\
\hline Brasil & Sitio São Domingos & Agronegócio \\
\hline Brasil & Sitio São Francisco & Agronegócio \\
\hline Brasil & Sitio São José (Boa Vista De Baixo) & Agronegócio \\
\hline
\end{tabular}




\begin{tabular}{|c|c|c|}
\hline Brasil & Sitio São José (Boa Vista De Cima) & Agronegócio \\
\hline Brasil & Sitio São José (Santo Antônio) & Agronegócio \\
\hline Brasil & Sitio São José (Seiva) & Agronegócio \\
\hline Brasil & Sitio São João Do Coqueiro & Agronegócio \\
\hline Brasil & Sitio São Judas Tadeu I & Agronegócio \\
\hline Brasil & Sitio São Paulo & Agronegócio \\
\hline Brasil & Sitio São Pedro & Agronegócio \\
\hline Brasil & Sitio São Sebastião (Anhumas) & Agronegócio \\
\hline Brasil & Sitio São Sebastião (Boa Vista De Baixo) & Agronegócio \\
\hline Brasil & $\begin{array}{l}\text { Socicana - Associação Produtores de cana de } \\
\text { Guariba }\end{array}$ & Agronegócio \\
\hline Brasil & Solazyme Bunge Produtos Renovaveis Ltda & Trader \\
\hline Brasil & São Fernando - Açúcar e Álcool LTDA & Indústria \\
\hline Brasil & Sítio Boa Vista & Agronegócio \\
\hline Brasil & Sítio Boa Vista Do Jacaré & Agronegócio \\
\hline Brasil & Sítio Córrego das Pedras & Agronegócio \\
\hline Brasil & Sítio do Vovô & Agronegócio \\
\hline Brasil & Sítio Macacos & Agronegócio \\
\hline Brasil & Sítio Maria Rosa & Agronegócio \\
\hline Brasil & Sítio Palmital & Agronegócio \\
\hline Brasil & Sítio Santa Cruz & Agronegócio \\
\hline Brasil & Sítio Santa Rosa & Agronegócio \\
\hline Brasil & Sítio Santo Antonio & Agronegócio \\
\hline Brasil & Sítio Santo Antonio (Boa Vista de Cima) & Agronegócio \\
\hline Brasil & Sítio Santo Antonio (Setecentos) & Agronegócio \\
\hline Brasil & Sítio Sonho Meu & Agronegócio \\
\hline
\end{tabular}




\begin{tabular}{|c|c|c|}
\hline Brasil & Sítio São Grether & Agronegócio \\
\hline Brasil & Sítio São Lucas I & Agronegócio \\
\hline Brasil & Sítio Três Irmãos & Agronegócio \\
\hline Brasil & Sonora Estancia S/A & Indústria \\
\hline Brasil & The Nature Conservancy & Soc Civil \\
\hline Brasil & $\begin{array}{c}\text { Usina Alto Alegre S.A. Açúcar e Ãlcool - } \\
\text { Unidade Junqueira }\end{array}$ & Indústria \\
\hline Brasil & Usina Açucareira São Manoel (Copersucar) & Indústria \\
\hline Brasil & Usina Açucareira Santa Adélia (Copersucar) & Indústria \\
\hline Brasil & Usina Açucareira Santo Antonio (Copersucar) & Indústria \\
\hline Brasil & Usina Serra Grande S/A & Indústria \\
\hline Brasil & Usina São José S/A & Indústria \\
\hline Brasil & Usina Trapiche & Indústria \\
\hline Brasil & Usina Vertente S/A & Indústria \\
\hline Brasil & Vale do Tijuco Açúcar e Álcool & Indústria \\
\hline Bélgica & Ecover Centro de Coordenação & Consumidor \\
\hline Camboja & Assinaturas da Ásia Ltda & Trader \\
\hline Canadá & Lantic Inc & Trader \\
\hline Canadá & Redpath Sugar Ltda & Trader \\
\hline Canadá & Sucro Can Inc. & Trader \\
\hline China & Guangxi East Asia Funan Sugar Refinery Co. Ltd & Indústria \\
\hline China & Guangxi Ningming East Asia Sugar Co Ltd & Indústria \\
\hline Cingapura & Wilmar Sugar Pte Ltda & Trader \\
\hline Colômbia & Alguimar / Balson & Agronegócio \\
\hline Colômbia & Ana Cristina Cabal Lynx & Agronegócio \\
\hline Colômbia & Asocaña & Indústria \\
\hline
\end{tabular}




\begin{tabular}{|c|c|c|}
\hline Colômbia & Castilla Riopaila & Indústria \\
\hline Colômbia & Chavarro Gaitan Hermanos & Agronegócio \\
\hline Colômbia & Guaduilla FAZENDAS. & Agronegócio \\
\hline Colômbia & Inversanchez S.A. & Agronegócio \\
\hline Colômbia & Jama \& Cia SCA & Agronegócio \\
\hline Colômbia & Josefina Nieto Barão & Agronegócio \\
\hline Colômbia & Osaavedral \& Cia SCS & Agronegócio \\
\hline Colômbia & Pecuária Tiacuante SAS & Agronegócio \\
\hline Colômbia & Procana & Agronegócio \\
\hline Colômbia & Rg Y Cia S Na C. S. & Agronegócio \\
\hline Colômbia & Victoria Racines Irmãos Lta & Agronegócio \\
\hline Dinamarca & Sugar Nordic - Sugar nord & Trader \\
\hline El Salvador & AGDYSA S.A. DE C.V. & Soc Civil \\
\hline El Salvador & Fedecañas & Soc Civil \\
\hline El Salvador & WIT O ANJO S.A. de C.V. & Indústria \\
\hline $\begin{array}{l}\text { Emirados } \\
\text { Árabes Unidos }\end{array}$ & MSM Trading International DMCC & Trader \\
\hline Espanha & Clarkson-Montesinos Institute & Soc Civil \\
\hline EUA & Amyris & Trader \\
\hline EUA & CHS. Inc & Trader \\
\hline EUA & CSC Sugar Llc & Trader \\
\hline EUA & General Mills Inc & Consumidor \\
\hline EUA & Instituto de Inovação Terra & Soc Civil \\
\hline EUA & International Finance Corporation (Ifc) & Trader \\
\hline EUA & Kellog Company & Consumidor \\
\hline EUA & Mondelez Internacional & Consumidor \\
\hline
\end{tabular}




\begin{tabular}{|c|c|c|}
\hline EUA & Pepsi Co & Consumidor \\
\hline EUA & Solazyme & Trader \\
\hline EUA & TechnoServe & Soc Civil \\
\hline EUA & The Coca-Cola Company & Consumidor \\
\hline EUA & World Wide Fund for Nature (WWF) & Soc Civil \\
\hline Fiji & Instituto de Pesquisa de Açúcar de Fiji & Agronegócio \\
\hline Filipinas & Universal Robina Corporation - Sonedco & Indústria \\
\hline França & Açúcar Ético & Soc Civil \\
\hline França & Fives Cail & Trader \\
\hline França & Grupo açúcares e produtos alimentares & Trader \\
\hline França & Pernod Ricard & Consumidor \\
\hline Guatemala & Mag Alcoholes, S.A. & Indústria \\
\hline Holanda & Corbion & Consumidor \\
\hline Holanda & eLEAF & Trader \\
\hline Holanda & Frieslandcampina Nederland $\mathrm{Bv}$ & Consumidor \\
\hline Holanda & Fundação Solidaridad & Soc Civil \\
\hline Holanda & Rabobank & Trader \\
\hline Holanda & Suikerunie & Trader \\
\hline Honduras & AZUNOSA- Açúcar do Norte, S.A. De Cv & Indústria \\
\hline Honduras & $\begin{array}{c}\text { Centro Nacional de Produção Mais Limpa em } \\
\text { Honduras - CNP LH }\end{array}$ & Soc Civil \\
\hline Indonésia & Pt. Dharamapala Sucesso Empresarial & Indústria \\
\hline Indonésia & PT KEBUN TEBU MAS & Indústria \\
\hline Indonésia & Jawamanis Rafinasi, PT & Trader \\
\hline Indonésia & PT. SUGAR LABINTA & Trader \\
\hline Israel & Sugat Sugar Refineries LTD & Trader \\
\hline
\end{tabular}




\begin{tabular}{|c|c|c|}
\hline Itália & Achard Italia SpA & Trader \\
\hline Itália & Alimco SpA & Trader \\
\hline Japão & Toyota Tsusho Corporation & Trader \\
\hline Luxemburgo & Ferrero Negociação Lux S.A. & Consumidor \\
\hline Malawi & Concern Universal Malawi & Soc Civil \\
\hline México & ADN fresco SPR & Agronegócio \\
\hline Maurício & Omnicane Limited & Indústria \\
\hline Maurício & Sonoo Estates Ltd & Agronegócio \\
\hline México & Ingenio Lazaro Cardenas & Indústria \\
\hline México & $\begin{array}{c}\text { Programas de Certificação para a Sociedade Civil } \\
\text { Sustentável (Psc) }\end{array}$ & Soc Civil \\
\hline México & Save The Children México & Soc Civil \\
\hline Nicarágua & La Isla Fundação & Soc Civil \\
\hline Nicarágua & Nicaragua Sugar Estates Limited & Indústria \\
\hline Nicarágua & União Agrícola & Agronegócio \\
\hline Paquistão & Ashraf Sugar Mills Limited & Indústria \\
\hline Paquistão & Chanar Sugar Mills Ltd & Indústria \\
\hline Paquistão & Farmers Associates Pakistan & Agronegócio \\
\hline Paquistão & Ijaz Ahmad & Agronegócio \\
\hline Paquistão & $\begin{array}{c}\text { O Thal Industries Corporation Limited (Layyah } \\
\text { Sugar Mills) }\end{array}$ & Indústria \\
\hline Paquistão & Shakarganj Mills Ltda & Indústria \\
\hline Reino Unido & Binge Sugars Ltd. & Trader \\
\hline Reino Unido & BP Biofuels Uk Ltd & Trader \\
\hline Reino Unido & Carbon Gold Ltd & Trader \\
\hline Reino Unido & E \& F Man & Trader \\
\hline Reino Unido & ECOM AGROTRADE Limitada (antiga Armajaro & Trader \\
\hline
\end{tabular}




\begin{tabular}{|c|c|c|}
\hline & Trading Ltd) & \\
\hline Reino Unido & HSBC Holdings PLC. & Trader \\
\hline Reino Unido & Mars Incorporated & Consumidor \\
\hline Reino Unido & Nações Melaço Trading Ltd & Trader \\
\hline Reino Unido & Proforest & Soc Civil \\
\hline Reino Unido & Shell International Petroleum Company & Consumidor \\
\hline Reino Unido & Trakeo & Trader \\
\hline Reino Unido & Unilever R \& D Vlaardingen BV. & Consumidor \\
\hline $\begin{array}{c}\text { Rep. } \\
\text { Dominicana }\end{array}$ & $\begin{array}{l}\text { Consorcio Azucarero de Empresas Industriales } \\
\text { (CAEI) }\end{array}$ & Indústria \\
\hline Suazilândia & Suazilândia Associação de Açúcar (SSA) & Soc Civil \\
\hline Suazilândia & Suazilândia Cane Growers Association & Agronegócio \\
\hline Suazilândia & Tambunkulu Estate & Agronegócio \\
\hline Sudão & Kenana Sugar Company & Indústria \\
\hline Suécia & Cloetta $\mathrm{AB}$ & Consumidor \\
\hline Suíça & Alvean Sugar S.L. & Trader \\
\hline Suíça & Bacardi - Martini Bv & Consumidor \\
\hline Suíça & Nestle $\mathrm{Sa}$ & Consumidor \\
\hline Suíça & Sabmiller & Consumidor \\
\hline Tailândia & KI Sugar Group & Indústria \\
\hline Tailândia & KSL Group & Indústria \\
\hline Tailândia & Mitr Phol Group - Tailândia & Indústria \\
\hline Tailândia & Thai Roong Ruang (TRR) Sugar Group & Indústria \\
\hline Uganda & Sugar Corporation Of Uganda Ltd. -Scoul & Indústria \\
\hline Índia & AJS Farms & Agronegócio \\
\hline Índia & Alangadu & Agronegócio \\
\hline
\end{tabular}




\begin{tabular}{|c|c|c|}
\hline Índia & Alawa Agri Farm & Agronegócio \\
\hline Índia & ARADHYA GARDEN & Agronegócio \\
\hline Índia & Balamarathu Thottam & Agronegócio \\
\hline Índia & BANNARI AMMAN SUGARS LIMITED & Indústria \\
\hline Índia & Barda Krish Farm & Agronegócio \\
\hline Índia & Bhalkya Krishi Farm & Agronegócio \\
\hline Índia & Chaudhari Krishi Farm & Agronegócio \\
\hline Índia & Chauhan Krishi Farm & Agronegócio \\
\hline Índia & Chauhan Krishi Farm II & Agronegócio \\
\hline Índia & Chauhan Krishi Farm III & Agronegócio \\
\hline Índia & Chella Darbar Farm & Agronegócio \\
\hline Índia & Chetti Thottam & Agronegócio \\
\hline Índia & Darbar Krishi Farm & Agronegócio \\
\hline Índia & De Jaya Kumar B Farm & Agronegócio \\
\hline Índia & De Pachiyappan E Farm & Agronegócio \\
\hline Índia & Dhanare Krishi Farm & Agronegócio \\
\hline Índia & Dhandapani Farm & Agronegócio \\
\hline Índia & Diferente Farm Agro & Agronegócio \\
\hline Índia & Do Periyasamy Martin Farm & Agronegócio \\
\hline Índia & Do T E Farm & Agronegócio \\
\hline Índia & Eid Parry India Ltd & Agronegócio \\
\hline Índia & Em RSCL & Agronegócio \\
\hline Índia & En G Chave Organic Farm & Agronegócio \\
\hline Índia & Fazenda B Ramalingam & Agronegócio \\
\hline Índia & Fazenda de Babu N & Agronegócio \\
\hline Índia & Fazenda de Dasini crawford & Agronegócio \\
\hline
\end{tabular}




\begin{tabular}{|c|c|c|}
\hline Índia & Fazenda de Dr.B.Rajamanickam & Agronegócio \\
\hline Índia & Fazenda de Jaya Raman & Agronegócio \\
\hline Índia & Fazenda de k Senthilraj celeb & Agronegócio \\
\hline Índia & Fazenda de Kannan V & Agronegócio \\
\hline Índia & Fazenda de Kumar K & Agronegócio \\
\hline Índia & Fazenda de Mari Muthu & Agronegócio \\
\hline Índia & Fazenda de Narayanan k & Agronegócio \\
\hline Índia & Fazenda de Ragoth Kumar.k & Agronegócio \\
\hline Índia & Fazenda de Rajendran M & Agronegócio \\
\hline Índia & Fazenda de Raju K & Agronegócio \\
\hline Índia & Fazenda de Rani P & Agronegócio \\
\hline Índia & Fazenda de Tanvi & Agronegócio \\
\hline Índia & Fazenda de Udhaya sankar N & Agronegócio \\
\hline Índia & Fazenda Parthipan T & Agronegócio \\
\hline Índia & Fazendas Dhangar Krishi & Agronegócio \\
\hline Índia & Gandhi s Farm & Agronegócio \\
\hline Índia & Gaur Krishi Farm & Agronegócio \\
\hline Índia & Hari om casa Farm & Agronegócio \\
\hline Índia & Jagan Agri Farm & Agronegócio \\
\hline Índia & Jain Krishi Farm & Agronegócio \\
\hline Índia & Jat Agri Farm & Agronegócio \\
\hline Índia & Jat Agri Farm II & Agronegócio \\
\hline Índia & Joshi Krishi Farm & Agronegócio \\
\hline Índia & Joshi Krishi Farm II & Agronegócio \\
\hline Índia & Kanakkupillai Thottam & Agronegócio \\
\hline Índia & Karna Candy Pvt Ltd & Consumidor \\
\hline
\end{tabular}




\begin{tabular}{|c|c|c|}
\hline Índia & Karumpukattu Thottam II & Agronegócio \\
\hline Índia & Karuvelamarathu Thottam & Agronegócio \\
\hline Índia & Khan Krishi Farm & Agronegócio \\
\hline Índia & Khedut Índia & Agronegócio \\
\hline Índia & Kinathankattu Thottam & Agronegócio \\
\hline Índia & Kovilthottam & Agronegócio \\
\hline Índia & Kumawat Krishi Farm & Agronegócio \\
\hline Índia & Kumawat Krishi Farm II & Agronegócio \\
\hline Índia & M L Venkatakrishna & Agronegócio \\
\hline Índia & Madmale Krishi Farm & Agronegócio \\
\hline Índia & Mahajan Krish Farm & Agronegócio \\
\hline Índia & Mahar Agri Farm & Agronegócio \\
\hline Índia & Mahar Agri Farm II & Agronegócio \\
\hline Índia & Mahar Agri Farm III & Agronegócio \\
\hline Índia & Mahar Farm House & Agronegócio \\
\hline Índia & Mahar Krishi Farm III & Agronegócio \\
\hline Índia & Mahar Krishi Farm IV & Agronegócio \\
\hline Índia & Mahar Krishi Farm V & Agronegócio \\
\hline Índia & Mahar Krishi Farm VI & Agronegócio \\
\hline Índia & Mahar Krishi Farm VII & Agronegócio \\
\hline Índia & Mahar Krishi Fazenda II & Agronegócio \\
\hline Índia & Mandloi Krishi Farm & Agronegócio \\
\hline Índia & Mandloi Krishi Farm & Agronegócio \\
\hline Índia & Mandloi Krishi Farm & Agronegócio \\
\hline Índia & Mandloi Krishi Farm II & Agronegócio \\
\hline Índia & Mandloi Krishi Farm III & Agronegócio \\
\hline
\end{tabular}




\begin{tabular}{|c|c|c|}
\hline Índia & Mandloi Krishi Farm IV & Agronegócio \\
\hline Índia & Mandloyee Krishi Farm & Agronegócio \\
\hline Índia & Mandloyee Krishi Farm & Agronegócio \\
\hline Índia & Mandloyee Krishi Farm & Agronegócio \\
\hline Índia & Mandloyee Krishi Farm II & Agronegócio \\
\hline Índia & Manegaon Farm & Agronegócio \\
\hline Índia & Mangala Farm House & Agronegócio \\
\hline Índia & Mettu Thotam & Agronegócio \\
\hline Índia & Mettukattu Thottam & Agronegócio \\
\hline Índia & Munda Krish Farm & Agronegócio \\
\hline Índia & Mukati Krish Famr III & Agronegócio \\
\hline Índia & Nagarajan Farm & Agronegócio \\
\hline Índia & Navegar Farmhouse & Agronegócio \\
\hline Índia & Nishanth Farm & Agronegócio \\
\hline Índia & OKRR Farm & Agronegócio \\
\hline Índia & Olam Agro India Ltd & Agronegócio \\
\hline Índia & Oor Thottam & Agronegócio \\
\hline Índia & Palakkattu Thottam & Agronegócio \\
\hline Índia & Patel Krishi Farm & Agronegócio \\
\hline Índia & Patel Krishi Farm & Agronegócio \\
\hline Índia & Patel Krishi Farm & Agronegócio \\
\hline Índia & Patel Krishi Farm & Agronegócio \\
\hline Índia & Patel Krishi Farm & Agronegócio \\
\hline Índia & Patel Krishi Farm & Agronegócio \\
\hline Índia & Patel Krishi Farm II & Agronegócio \\
\hline Índia & Patel Krishi Farm II & Agronegócio \\
\hline
\end{tabular}




\begin{tabular}{|c|c|c|}
\hline Índia & Patel Krishi Farm II & Agronegócio \\
\hline Índia & Patel Krishi FarmVI & Agronegócio \\
\hline Índia & Patidar Farm casa II & Agronegócio \\
\hline Índia & Patidar Farm casa III & Agronegócio \\
\hline Índia & Patidar Farm casa IV & Agronegócio \\
\hline Índia & Patidar Farm House & Agronegócio \\
\hline Índia & Patidar Farm House V & Agronegócio \\
\hline Índia & Patidar Krishi Farm & Agronegócio \\
\hline Índia & Patidar Krishi Farm & Agronegócio \\
\hline Índia & Patidar Krishi Farm & Agronegócio \\
\hline Índia & Patidar Krishi Farm II & Agronegócio \\
\hline Índia & Patidar Krishi Farm II & Agronegócio \\
\hline Índia & Patidar Krishi Farm II & Agronegócio \\
\hline Índia & Patidar Krishi Farm III & Agronegócio \\
\hline Índia & Patidar Krishi Farm III & Agronegócio \\
\hline Índia & Patidar Krishi Farm IV & Agronegócio \\
\hline Índia & Patidar Krishi Farm IV & Agronegócio \\
\hline Índia & Patidar Krishi Farm V & Agronegócio \\
\hline Índia & Patidar Krishi Farm V & Agronegócio \\
\hline Índia & Perda Oothu & Agronegócio \\
\hline Índia & Periyaveettu Valavu & Agronegócio \\
\hline Índia & Prajapati Krishi Farm & Agronegócio \\
\hline Índia & Prajapati Krishi Farm II & Agronegócio \\
\hline Índia & PRAMICA TOTTAM & Agronegócio \\
\hline Índia & Prove Fazenda de K & Agronegócio \\
\hline Índia & Rajpoot Agro Farm & Agronegócio \\
\hline
\end{tabular}




\begin{tabular}{|c|c|c|}
\hline Índia & Rajpoot Krishi Farm & Agronegócio \\
\hline Índia & Rajpoot Krishi Farm & Agronegócio \\
\hline Índia & Rajpoot Krishi Farm & Agronegócio \\
\hline Índia & Rajshree Açúcares e Produtos Químicos LTD. & Indústria \\
\hline Índia & Ramesh Marappan & Agronegócio \\
\hline Índia & Ranveer Krishi Farm & Agronegócio \\
\hline Índia & Ranveer Krishi Farm & Agronegócio \\
\hline Índia & Rathod Krishi Farm & Agronegócio \\
\hline Índia & Rathod Krishi Farm II & Agronegócio \\
\hline Índia & Rathod Krishi Farm III & Agronegócio \\
\hline Índia & Rawat Agri Farm & Agronegócio \\
\hline Índia & Rewa Farm House & Agronegócio \\
\hline Índia & Rishikaa adrika Farm & Agronegócio \\
\hline Índia & RSCI II & Agronegócio \\
\hline Índia & RSCK XXIII & Agronegócio \\
\hline Índia & RSCL & Agronegócio \\
\hline Índia & RSCL & Agronegócio \\
\hline Índia & RSCL II & Agronegócio \\
\hline Índia & RSCL III & Agronegócio \\
\hline Índia & RSCL IV & Agronegócio \\
\hline Índia & RSCL V & Agronegócio \\
\hline Índia & RSCL VI & Agronegócio \\
\hline Índia & RSCL VII & Agronegócio \\
\hline Índia & RSCL VIII & Agronegócio \\
\hline Índia & RSCL X & Agronegócio \\
\hline Índia & RSCL X & Agronegócio \\
\hline
\end{tabular}




\begin{tabular}{|c|c|c|}
\hline Índia & RSCL XI & Agronegócio \\
\hline Índia & RSCL XI & Agronegócio \\
\hline Índia & RSCL XII & Agronegócio \\
\hline Índia & RSCL XIII & Agronegócio \\
\hline Índia & RSCL XIV & Agronegócio \\
\hline Índia & RSCL XIX & Agronegócio \\
\hline Índia & RSCL XV & Agronegócio \\
\hline Índia & RSCL XVI & Agronegócio \\
\hline Índia & RSCL XVII & Agronegócio \\
\hline Índia & RSCL XVIII & Agronegócio \\
\hline Índia & RSCL XX & Agronegócio \\
\hline Índia & RSCL XXI & Agronegócio \\
\hline Índia & RSCL XXII & Agronegócio \\
\hline Índia & RSCL XXIV & Agronegócio \\
\hline Índia & RSCL XXIV & Agronegócio \\
\hline Índia & RSCL XXV & Agronegócio \\
\hline Índia & RSCL XXVI & Agronegócio \\
\hline Índia & RSCL XXVII & Agronegócio \\
\hline Índia & RSCL XXVIII & Agronegócio \\
\hline Índia & RSCL XXX & Agronegócio \\
\hline Índia & RSCL XXXI & Agronegócio \\
\hline Índia & RSCL XXXII & Agronegócio \\
\hline Índia & RSCL XXXIII & Agronegócio \\
\hline Índia & RSCL XXXIV & Agronegócio \\
\hline Índia & RSCL XXXV & Agronegócio \\
\hline Índia & RSCL XXXVI & Agronegócio \\
\hline
\end{tabular}




\begin{tabular}{|c|c|c|}
\hline Índia & RSCL XXXVII & Agronegócio \\
\hline Índia & SAIFARM & Agronegócio \\
\hline Índia & Sada Farm & Agronegócio \\
\hline Índia & Sambasivareddy fazenda & Agronegócio \\
\hline Índia & Sanjay Farm & Agronegócio \\
\hline Índia & Santoshi Ma Krishi Farm & Agronegócio \\
\hline Índia & Semmanthundu Thottam & Agronegócio \\
\hline Índia & Shanmugha Sundaram Kacilingam & Agronegócio \\
\hline Índia & Shantilal Hari Patidar & Agronegócio \\
\hline Índia & Sharma Krishi Farm & Agronegócio \\
\hline Índia & Sharma Krishi Farm & Agronegócio \\
\hline Índia & Sharma Krishi Farm & Agronegócio \\
\hline Índia & Shishodia Krishi Farm & Agronegócio \\
\hline Índia & Shishodia Krishi Farm II & Agronegócio \\
\hline Índia & Singh Agri Farm & Agronegócio \\
\hline Índia & Solanki Krishi Farm & Agronegócio \\
\hline Índia & Solanki Krishi Farm & Agronegócio \\
\hline Índia & Solanki Krishi Farm & Agronegócio \\
\hline Índia & Subramaniyar thottam & Agronegócio \\
\hline Índia & Taophyk S Farm & Agronegócio \\
\hline Índia & Thasankattuthottam & Agronegócio \\
\hline Índia & Thulukkan Thottam & Agronegócio \\
\hline Índia & Tomar Krishi Farm & Agronegócio \\
\hline Índia & Vamos Farm House & Agronegócio \\
\hline Índia & Vamos Krishi Farm & Agronegócio \\
\hline Índia & Vamos Krishi Farm & Agronegócio \\
\hline
\end{tabular}




\begin{tabular}{|c|c|c|}
\hline Índia & Vamos Krishi Farm & Agronegócio \\
\hline Índia & Varappathi Kadu & Agronegócio \\
\hline Índia & Velliangkattu Thottam & Agronegócio \\
\hline Índia & Verma Krishi Farm & Agronegócio \\
\hline Índia & Vilangattar Casa & Agronegócio \\
\hline Índia & Visita Kaani & Agronegócio \\
\hline Índia & Viswanathan Govindasamy & Agronegócio \\
\hline Índia & Yadav Krishi Farm & Agronegócio \\
\hline Índia & Yadav Krishi Farm & Agronegócio \\
\hline Índia & Yadav Krishi Farm II & Agronegócio \\
\hline Índia & Yadav Krishi Farm III & Agronegócio \\
\hline Índia & Yadav Krishi Farm IV & Agronegócio \\
\hline Índia & Yadav Krishi Farm V & Agronegócio \\
\hline Índia & Yadav Krishi Fazenda & Agronegócio \\
\hline Índia & Yadav Krishi Fazenda II & Agronegócio \\
\hline
\end{tabular}

Fonte: elaborado pelo autor a partir de dados do BSI-BONSUCRO (2016) 


\section{ANEXO 2 - Usinas certificadas pelo BSI-Bonsucro (2015)}

\begin{tabular}{|c|c|}
\hline Grupo Certificado & País de origem \\
\hline Noble Group & Brasil \\
\hline Murugappa Group & Índia \\
\hline CMAA - Cia Mineira de Açúcar e Álcool & Brasil \\
\hline Bundaberg Sugar Ltd (De Milllaquin) & Austrália \\
\hline Bundaberg Sugar Ltd (De Bingera) & Austrália \\
\hline New South Wales Sugar Milling Co. Ltd & Austrália \\
\hline Raizen (Destivale) & Brasil \\
\hline Raizen (Diamante) & Brasil \\
\hline Copersucar (Santo Antônio) & Brasil \\
\hline SAB Miller & Honduras \\
\hline Guarani (Vertente) & Brasil \\
\hline Raízen (Serra) & Brasil \\
\hline Raízen (Junqueira) & Brasil \\
\hline Raízen (Dois córregos) & Brasil \\
\hline Odebrecht Agroindustrial (Morro Vermelho) & Brasil \\
\hline Guarani (Cruz Alta) & Brasil \\
\hline Guarani (Severínia) & Brasil \\
\hline São Martinho (Santa Criuz) & Brasil \\
\hline Copersucar (São Luiz) & Brasil \\
\hline Raízen (Univalem) & Brasil \\
\hline Adecoagro (Monte Alegre) & Brasil \\
\hline Raízen (Gase) & Brasil \\
\hline
\end{tabular}




\begin{tabular}{|c|c|}
\hline Odebrecht Agroindustrial (Rio Claro) & Brasil \\
\hline BP - Tropical Bioenergia & Brasil \\
\hline Raízen (Bonfim) & Brasil \\
\hline São Martinho (Iracema) & Brasil \\
\hline New South Wales (Broadwater) & Austrália \\
\hline New South Wales (Harwood) & Austrália \\
\hline LDC (Santa Elisa) & Brasil \\
\hline Alta Mogiana & Brasil \\
\hline Bunge (Guariroba) & Brasil \\
\hline Adecoagro (Angélica) & Brasil \\
\hline Bunge (Itapagipe) & Brasil \\
\hline Raízen (Jataí) & Brasil \\
\hline Usina São João & Brasil \\
\hline Raízen (Costa Pinto) & Brasil \\
\hline Raízen (Bom Retiro) & Brasil \\
\hline Odebrecht Agorambiental (Conquista) & Brasil \\
\hline Bunge (Fruto) & Brasil \\
\hline Bunge (Moema) & Brasil \\
\hline Copersucar (São José) & Brasil \\
\hline Copersucar (Barra Grande) & Brasil \\
\hline Copersucar (Santa Adelia) & Brasil \\
\hline Copersucar (São Manoel) & Brasil \\
\hline Copersucar (Quatá) & Brasil \\
\hline Raízen (Maracaí) & Brasil \\
\hline Junqueira & Brasil \\
\hline
\end{tabular}

Fonte: elaborado pelo autor a partir de dados do BSI-BONSUCRO (2015) 